PRIMAKOV NATIONAL RESEARCH INSTITUTE OF WORLD ECONOMY AND

INTERNATIONAL RELATIONS

RUSSIAN ACADEMY OF SCIENCES

(IMEMO)

\title{
RUSSIA: \\ ARMS CONTROL, \\ DISARMAMENT AND \\ INTERNATIONAL SECURITY
}

\author{
IMEMO SUPPLEMENT \\ TO THE RUSSIAN EDITION \\ OF THE SIPRI YEARBOOK 2019
}




\author{
PRIMAKOV NATIONAL RESEARCH \\ INSTITUTE OF WORLD ECONOMY AND \\ INTERNATIONAL RELATIONS \\ RUSSIAN ACADEMY OF SCIENCES
}

(IMEMO)

Russian edition of the SIPRI Yearbook 2019 is dedicated to the intellectual legacy of Academician Andrei Sakharov in the lead up to the $100^{\text {th }}$ anniversary of his birth

\title{
RUSSIA: \\ ARMS CONTROL, DISARMAMENT AND INTERNATIONAL SECURITY
}

\author{
IMEMO SUPPLEMENT \\ TO THE RUSSIAN EDITION \\ OF THE SIPRI YEARBOOK 2019
}

Foreword by Alexander Dynkin

Chief editors:

Alexey Arbatov, Sergey Oznobishchev

Editor: Marianna Yevtodyeva

Translation editor: Leon Geyer

\author{
Moscow \\ IMEMO \\ 2020
}


УДК 327

ББК 64.4(0)

Rus95

Rus95

Russia: Arms Control, Disarmament and International Security. IMEMO Supplement to the Russian Edition of the SIPRI Yearbook 2019 / Ed. by Alexey Arbatov, Sergey Oznobishchev, Leon Geyer and Marianna Yevtodyeva. - Moscow, IMEMO, 2020. - 175 p.

ISBN 978-5-9535-0578-9

DOI: $10.20542 / 978-5-9535-0578-9$

The volume provides IMEMO contributions to the Russian Edition of the 2019 SIPRI Yearbook: Armaments, Disarmament and International Security. It covers such important issues as challenges and options for strategic arms control, risks to the non-proliferation regime, threats of military use of artificial intelligence and current state of Russia-NATO relations. This year's volume also provides research on problems of development of the Middle East conflicts, activity of the Islamic State in the Middle East and Asia, Indian and Pakistani nuclear doctrines and strategies and the possibilities for cooperation and competition between countries in the Arctic region.

To view IMEMO publications, please visit our website at https://www.imemo.ru

ISBN 978-5-9535-0578-9

(C) IMEMO, 2020 


\section{CONTENTS}

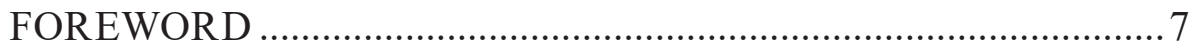

Alexander DYNKIN

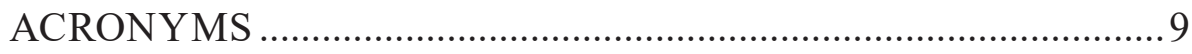

PART I. ANALYSES, FORECASTS AND DISCUSSIONS ....13

1. THE WORLD OF THE 2020S AND RUSSIA ………………...... 15

Dmitry TRENIN

2. STRATEGIC ARMS CONTROL: CHALLENGES

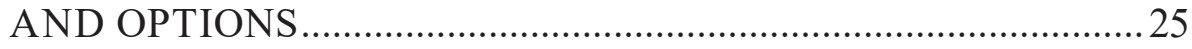

Alexey ARBATOV

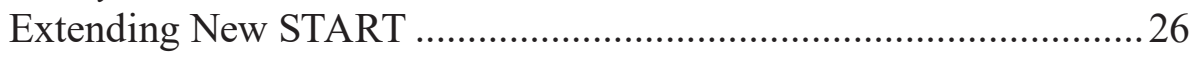

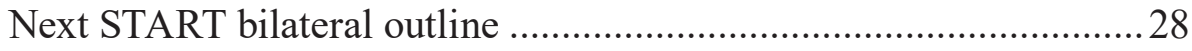

Preserving the core of the INF Treaty ……………………………....... 33

3. NPT PROBLEMS IN LIGHT OF INCREASED

COMPETITION IN THE GLOBAL MARKET OF

NUCLEAR MATERIALS AND TECHNOLOGIES ....................... 37

Anatoly DIAKOV

Nuclear fuel cycle and nuclear energy market at various

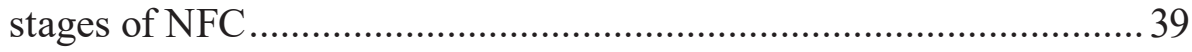

Competition and control of nuclear exports ......................................... 46

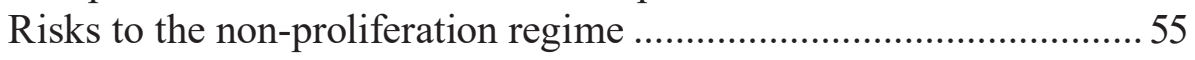

4. NATO-RUSSIA RELATIONS AND ARMS

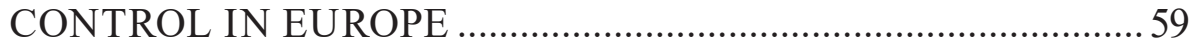

Sergey OZNOBISHCHEV

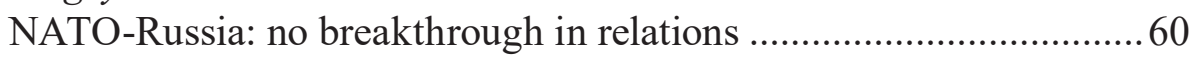

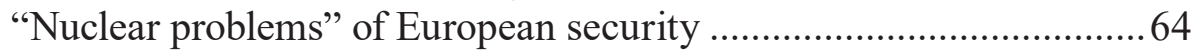

Conventional arms control in Europe: interrupted process................... 70 
5. CHALLENGES AND THREATS OF MILITARY USE

OF ARTIFICIAL INTELLIGENCE ............................................... 79

Pavel KARASEV

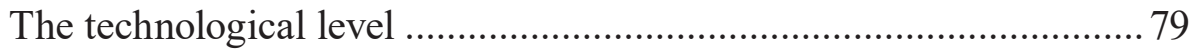

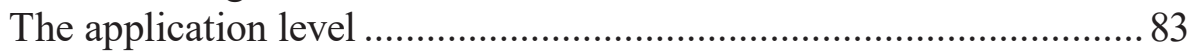

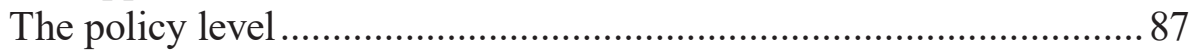

PART II. EXPERT INSIGHTS ...............................................95

6. ARCTIC IN THE HIGH POLITICS ……………………….........97

Andrei ZAGORSKI and Andrei TODOROV

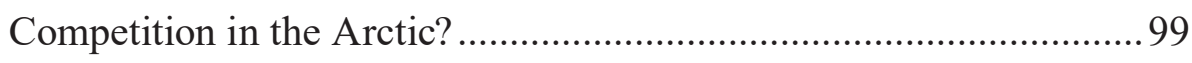

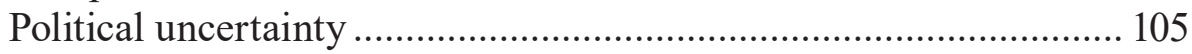

Introduction of the notification-based procedure for foreign

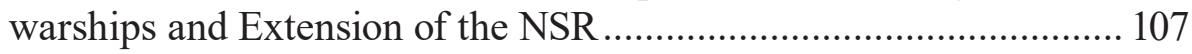

Russia's possible withdrawal from the 1990 Agreement.................... 112

7. MIDDLE EAST CONFLICTS: CORRELATION

BETWEEN LOCAL AND REGIONAL FACTORS...................... 115

Alexander SHUMILIN

Evolution of the concept "the Middle East conflict"........................... 115

From civil war to regional conflict..................................................117

Syria, Libya, Yemen: regional actors and strategies .......................... 120

Geopolitics in the context of religion ................................................. 128

8. THE INDO-PAKISTANI MUTUAL DETERRENCE:

STRATEGIC CULTURE AND NUCLEAR STRATEGY .......... 133

Konstantin BOGDANOV and Alexey KUPRIYANOV

India: nuclear project development .................................................... 133

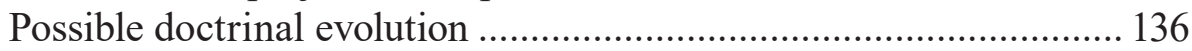

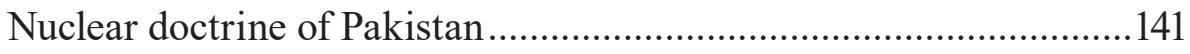

"Cold Start": impact on Pakistani nuclear strategy............................. 143

9. TRANSFORMATION OF THE ISLAMIC STATE ................. 151

Stanislav IVANOV

IS in the Middle East region and Asia ................................................ 153 
Likelihood of increased IS activity in Central Asian and CIS countries..... 158

Threat of IS penetration into Russia .......................................... 160

\section{PART III. DOCUMENTS AND REFERENCE}

MATERIALS ........................................................................ 163

10. KEY DOCUMENTS OF THE RUSSIAN

FEDERATION ON NATIONAL SECURITY, DEFENSE

AND ARMS CONTROL (JANUARY - DECEMBER 2019)...... 165

Sergey TSELITSKY

Legislative acts.

Normative acts of the executive power

ABOUT THE CONTRIBUTORS ............................................ 173 


\section{FOREWORD}

This edition was conceived in 1993 as a joint project of the Stockholm International Peace Research Institute (SIPRI) and the National Research Institute of World Economy and International Relations of the Russian Academy of Sciences (IMEMO RAS). An important part of this idea was the annual issue of the IMEMO Special Supplement to the SIPRI Yearbook, authored by the Institute's leading scholars.

This year's edition of the SIPRI Yearbook in Russian is dedicated to the memory of the outstanding Soviet scientist Andrei Sakharov, whose centenary will be celebrated in 2021. Academician Andrei D. Sakharov was at the origins of nuclear weapons, and he was one of the most prominent peace activists in the USSR and abroad who advocated for human rights and for an end of the nuclear arms race.

The Special Supplement opens with a conceptual review of the world of 2020s, which has striking differences from previous periods of development of international relations. The edition also provides an in-depth analysis of the current acute stage of arms control, primarily in the field of strategic offensive arms, problems of nuclear nonproliferation in light of increasing competition in the nuclear materials and technologies market, and the possibilities of conventional arms control in Europe in the context of NATO-Russia relations. One of the chapters is focused on the "innovative" topic of challenges and threats of military use of artificial intelligence.

In the Supplement's Part II, Expert Insights, some current regional topics are detailed: policy of the leading states in the Arctic, analysis of the Middle East conflicts and tensions in the region, mutual nuclear deterrence of India and Pakistan, the transformation of the Islamic State terrorist organization (banned in Russia). The Supplement traditionally contains also background information an overview of the key documents of the Russian Federation on national security, defence and arms control in 2019. 
The creation and editing of the SIPRI 2019 Yearbook in Russian was led by Alexey Arbatov and Sergey Oznobishchev. Marianna Yevtodyeva has coordinated the work for preparing and publishing the SIPRI Yearbook and the IMEMO Special Supplement. Konstantin Bogdanov has made an important contribution to this work.

I would like to thank in particular the authors of the IMEMO Special Supplement: Alexey Arbatov, Konstantin Bogdanov and Alexey Kupriyanov, Anatoly Diakov, Andrei Zagorski and Andrei Todorov, Stanislav Ivanov, Pavel Karasev, Sergey Oznobishchev, Dmitry Trenin, Alexander Shumilin and Sergey Tselitsky.

I express deep gratitude to the Swiss Federal Department of Defence, Civil Protection and Sport for supporting of this publication.

Academician Alexander Dynkin President of the Primakov National Research Institute of World Economy and International Relations of the Russian Academy of Sciences

July 2020 


\section{ACRONYMS}

$\begin{array}{ll}\text { AC } & - \text { Arctic Council } \\ \text { ACV } & - \text { armoured combat vehicle } \\ \text { AI } & - \text { artificial intelligence } \\ \text { ALCM } & - \text { air-launched cruise missile } \\ \text { ASAT } & - \text { anti-satellite weapons } \\ \text { AZRF } & - \text { Arctic Zone of the Russian Federation } \\ \text { BJP } & - \text { Bharatiya Janata Party } \\ \text { BMD } & - \text { ballistic missile defence } \\ \text { BRICS } & - \text { Brazil, Russia, India, China, and South Africa } \\ \text { CACE } & - \text { conventional arms control in Europe } \\ \text { CCW } & - \text { 1980 Convention on Certain Conventional Weapons } \\ \text { CFE } & - \text { 1990 Treaty on Conventional Armed Forces in } \\ & - \text { Europe } \\ \text { CLCS } & - \text { Commission on the Limits of the Continental Shelf } \\ \text { COVID-19 } & - \text { Coronavirus disease 2019 } \\ \text { CSA } & - \text { IAEA Comprehensive Safeguards Agreement } \\ \text { CSTO } & - \text { Collective Security Treaty Organization } \\ \text { CTBT } & - \text { 1996 Comprehensive Nuclear-Test-Ban Treaty } \\ \text { DARPA } & - \text { Defense Advanced Research Projects Agency } \\ \text { DCA } & - \text { dual-capable aircraft } \\ \text { EWS } & - \text { early warning system } \\ \text { FMCT } & - \text { Fissile Material Cut-off Treaty } \\ \text { FON } & - \text { 'Freedom of Navigation' program } \\ \text { GGE } & - \text { UN Group of Governmental Experts } \\ \text { GNA } & - \text { Libyan Government of National Accord } \\ \text { IAEA } & - \text { International Atomic Energy Agency } \\ \text { ICAO } & - \text { International Civil Aviation Organization } \\ \text { ICBM } & - \text { intercontinental ballistic missile } \\ \text { ICT } & - \text { information and communication technology } \\ \text { IHL } & - \text { international humanitarian law } \\ \text { IMU } & - \text { Islamic Movement of Uzbekistan } \\ \text { INF Treaty } & - \text { 1987 Treaty on the Elimination of Intermediate- } \\ \text { IR(B)M } & - \text { intermediate-range (ballistic) missile } \\ & \end{array}$




\begin{tabular}{|c|c|}
\hline IRGC & - Islamic Revolutionary Guard Corps \\
\hline IS (ISIL) & - Islamic State (Islamic State of Iraq and the Levant) \\
\hline LAWS & - lethal autonomous weapon systems \\
\hline LNA & - Libyan National Army \\
\hline MIRV & - multiple independently targeted re-entry vehicle \\
\hline MOX & - mixed oxide fuel \\
\hline NATO & - North Atlantic Treaty Organisation \\
\hline New START & $\begin{array}{l}\text { - } 2010 \text { Treaty on Measures for the Further Reduction } \\
\text { and Limitation of Strategic Offensive Arms }\end{array}$ \\
\hline $\mathrm{NFC}$ & - nuclear fuel cycle \\
\hline NPP & - nuclear power plant \\
\hline NPT & $\begin{array}{l}\text { - } 1968 \text { Treaty on the Nonproliferation of Nuclear } \\
\text { Weapons }\end{array}$ \\
\hline $\mathrm{NRC}$ & - NATO-Russia Council \\
\hline NSG & - Nuclear Suppliers Group \\
\hline NSR & - Northern Sea Route \\
\hline NSTK & - Northern Sea Transport Corridor \\
\hline OSCE & - Organization for Security and Cooperation in \\
\hline Europe & \\
\hline OST & - 1992 Treaty on Open Skies \\
\hline $\mathrm{R} \& \mathrm{D}$ & - research \& development \\
\hline SALT I & $\begin{array}{l}1972 \text { Interim Agreement on Certain Measures with } \\
\text { Respect to the Limitation of Strategic Offensive } \\
\text { Arms }\end{array}$ \\
\hline SALT II & - 1979 Strategic Arms Limitation Treaty \\
\hline SLBM & - submarine-launched ballistic missile \\
\hline SLCM & - sea-launched cruise missile \\
\hline SNEPP & $\begin{array}{l}\text { - Subterranean Nuclear Explosion for Peaceful } \\
\text { Purposes }\end{array}$ \\
\hline SNF & - spent nuclear fuel \\
\hline SORT & $\begin{array}{l}\text { - } 2002 \text { Strategic Offensive Reductions Treaty } \\
\text { (Moscow Treaty) }\end{array}$ \\
\hline START I & - 1991 Strategic Arms Reduction Treaty \\
\hline START II & - 1993 Strategic Arms Reduction Treaty \\
\hline SWU & - separative work unit \\
\hline TLE & - CFE treaty-limited equipment \\
\hline
\end{tabular}




$\begin{array}{ll}\text { TNW } & - \text { tactical nuclear weapons } \\ \text { UAV } & - \text { unmanned aerial vehicle } \\ \text { UN } & - \text { United Nations } \\ \text { UNCLOS } & - \text { 1982 United Nations Convention on the Law of the } \\ & \quad \text { Sea } \\ \text { UNESCO } & - \text { United Nations Educational, Scientific and Cultural } \\ & \quad \text { Organization } \\ \text { UNSCR } & - \text { United Nations Security Council Resolution } \\ \text { VD } & - \text { 2011 Vienna Document } \\ \text { WHO } & - \text { World Health Organization } \\ \text { WNA } & - \text { World Nuclear Association }\end{array}$




\section{PART I. ANALYSES, FORECASTS AND DISCUSSIONS}

1. The world of the 2020s and Russia

2. Strategic arms control: challenges and options

3. NPT problems in light of the increased competition on the nuclear materials and technologies market

4. NATO-Russia relations and arms control in Europe

5. Challenges and threats of military use of artificial intelligence 


\section{THE WORLD OF THE 2020S AND RUSSIA ${ }^{1}$}

\section{Dmitry TRENIN}

The 2020s have opened with a global crisis caused by the pandemic of COVID-19. This crisis has reinforced the trends that have been developing since the turn of the century. As a result, a clearer image of the world of the 2020s has emerged.

Globalization goes on, yet it is acquiring new features. Although the world remains global, it is becoming less homogeneous and more fractured and diverse. The United Nations retains its unique role as a universal forum for dialogue, rather than a centre for discussing, let alone making, decisions of paramount importance. The elements of the United Nations system, such as the World Trade Organization, the International Monetary Fund, the World Bank, the World Health Organization (WHO), and UNESCO, continue to lose their influence. This is mainly caused by the gradual decline of American global leadership, a greater focus of the United States on its internal affairs, and the loss of interest by Washington in supporting the global institutions that the United States is no longer able to control.

The United States, the leader and ideologist of globalization, has become preoccupied with itself since the pandemic commenced. Contrary to the usual practice of many years, Washington made no attempts to provide assistance to other countries. Instead, America has taken vigorous steps to isolate itself from the rest of the world, reserve a future coronavirus vaccine for itself, and condemn China as the source of the pandemic, demanding that it should pay enormous reparations to the victims of the virus. As part of this anti-China campaign, the U.S.A. has suspended its funding to the WHO and severed contact with it.

An apparent weakening of American leadership has also affected the role of the special consultative bodies - the G 7 and the G 20. G 7 annual meetings have in fact lost their importance as political highlights of a year. The G 20, which got off to a good start

1 The data in this volume is as of 1 June 2020. 
when the 2008 crisis broke out, has turned into a protocol format. Russia has proposed reviving the P-5 format (a summit of the permanent members of the UN Security Council), yet its proposal will hardly revitalize the cooperation among the states entrusted with primary responsibility for the maintenance of international peace and security in accordance with the Charter of the United Nations. After the United States gave it up, global leadership has not been assumed by any other major player such as China, the European Union, or an alliance such as BRICS. Thus, as the United States has ceased to be the global hegemon and Washington is unwilling to join in the international efforts, one can expect a vacuum of leadership as such to appear in the foreseeable future, with the individual leadership having already ended and collective leadership not being yet in place.

The United States' withdrawal will have a long-term impact on the evolution of the structure of the modern Western world. The divide between America and Europe is notably widening. As a result, a single structure is being replaced by a two-component arrangement, with the European Union, on the one hand, and the United States and its closest English-speaking allies, such as the United Kingdom, Canada, Australia, and New Zealand, on the other. One should make a special mention of Washington's non-Western allies - Japan, South Korea, Singapore, and some other countries. So far, the Western community is not split, but undergoing a structural transformation. Its former structure is challenged by Washington rather than by its allies who still remain intensely loyal to the United States. The country's foreign policy is almost certain to be considerably revised and adjusted in case the Democratic Party's candidate is elected as the $46^{\text {th }}$ President of the United States in November 2020, nevertheless, the general course of the United States' politics towards the strengthening of the country amidst the confrontation with its competitors and rivals is likely to remain.

The United States-led politico-military alliances, both multilateral (such as NATO) and bilateral (such as the United StatesJapan Security Treaty), look increasingly outdated. The Collective Security Treaty Organization (CSTO) established by Russia remains a modest military cooperation body. In the dynamic environment of 
the 2020s and 2030s, ad-hoc alliances to address specific tasks, limited in space, time, and scope, appear to be more appropriate. In this vein, the United States are strengthening the Quadrilateral Security Dialogue among the United States, Japan, India, and Australia (The Quad) with a view to deterring China, while Russia has been establishing ad-hoc partnerships in the Middle East.

Regional economic alliances of integrative (the European Union) and cooperative (the Eurasian Economic Union) nature are in keeping with the general trend towards regionalism in the world economy and politics. However, in these organizations, intergovernmental relations have come to prevail over supranational bodies. Not only external players, but the members of such alliances, themselves, are encouraged to build bilateral relationships.

In the political sphere, prioritizing domestic decisions, including on global issues, puts a higher value on national sovereignty. Border controls restored or reinforced during the pandemic, will partially remain in place in the foreseeable future. Hence, mass migration of people in quest of a better life will encounter more barriers.

In addition to the fact that states are playing an increased role in the international system, governments are assuming roles of more importance within their respective countries. Ever more often, they choose to pursue national interests rather than international obligations. Moderate nationalism is becoming a clearer and even the prevailing trend. On the contrary, transnational actors have weakened across the world, yet they are far from defeated. The struggle is continuing. Nationalism itself needs to be reaffirmed. Against this background, internal solidarity in all nations is put to the test, while states - and not only those with federal systems of government - are also being tested for the strength of their internal structure in terms of ties between their centre and periphery. As for the citizens, the rights-to-duties ratio, in which rights dominated for a long time, has started shifting towards duties. Digitalization is becoming a most powerful instrument of public - and in authoritarian societies also of political - control.

As the conflict proneness of the world politics is increasing, political leadership, including personal one, is taking on added importance. The rapidly changing environment calls for "manual 
control" of institutions on the part of leaders. In the European Union, the lack of leadership has turned out to be a fundamental problem for Europe. In the United States, with the political community and society deeply divided, unity-oriented leadership appears almost impossible in the coming years. The internal instability in the United States has become one of the major factors behind international uncertainty. Countries with authoritarian or personalist regimes, such as China, Russia, Turkey, Iran, etc., are experiencing problems of quite another sort - for example, those related to the succession or legitimacy of the authorities. Confident leadership is certainly preferable to no leadership, yet in the long run institutions win.

The world economy is shifting towards self-dependency of states. The old production chains are broken, while new ones are being formed. Economic feasibility is no longer the main factor to take into account when making investment decisions. The competition among transnational companies is giving way to economic competition among states. State policy is to a much greater extent being driven by the interests of the national economic, technological, and health security. The importance of critical technologies has grown dramatically; companies are opting for reshoring manufacturing back home. In these circumstances, international trade will either be shrinking or growing slowly. The United States dollar remains the world's dominant reserve currency, the influence of the euro is not increasing, the renminbi (the Chinese yuan), including as a cryptocurrency, will strive to expansion although its spread will be limited as a result of a number of structural obstacles. A sharp drop in oil prices might be a sign of a fundamental decline in the demand for hydrocarbons in the medium term. That signifies that Russia is facing a major challenge.

Such big changes have serious ideological consequences. The liberal order underpinning globalization and based on free trade has suffered a serious, although not a fatal, blow. In the future, the sphere of dominance of this order will be reduced to the geographic scope of the political West and its constituency. The defeat of liberal democracy, however, does not involve the strengthening of conservatism and authoritarianism. The United States and the Atlantic elites of Europe will 
hardly succeed in their attempts, for the purpose of their consolidation, at reviving the spectre of communism, this time represented by China and linked to Russian authoritarianism.

The clash between democracy and communism is a matter of the past century. It has now been replaced by the issues of good and poor governance. The COVID-2019 pandemic has highlighted three factors determining the resilience of states and societies. Those are (a) competencies and the quality of governance; (b) culture of society and the level of its self-organization, (c) the strength of ties and the level of trust between those governed and those who govern. Those factors in combination will probably determine the fate of political regimes in the $21^{\text {st }}$ century. This is true of both authoritarian regimes and Western democracies.

There will be further weakening of the international security regimes as the system of arms control created during and after the Cold War is being dismantled. The United States' withdrawal from the Open Skies Treaty ${ }^{2}$ in 2020 has been the third step taken by the Trump administration to remove any limitations to the country in this respect after its withdrawal from the Joint Comprehensive Plan of Action on Iranian nuclear program in 2017 and denunciation of the IntermediateRange Nuclear Forces Treaty in 2019. The prospects of the extension of the New START (Treaty on Measures for the Further Reduction and Limitation of Strategic Offensive Arms) are vanishing. Washington has literally discarded arms control as an obstacle preventing America from gaining military-technical advantages over its potential adversaries, Russia and China.

The pandemic has had practically no effect on the international and internal conflicts. The situation in Donbass, Syria, Libya, Yemen, Afghanistan, and other conflict zones is following the trajectories that had been shaped long before the pandemic. Russia's proposals to partially lift the sanctions limiting economic ties with a number of countries with special difficulties, such as Venezuela and Iran, were ignored. On

2 Sanger, D. E., 'Trump Will Withdraw from Open Skies Arms Control Treaty', The New York Times, 21 May $2020<$ https://www.nytimes.com/2020/05/21/us/ politics/trump-open-skies-treaty-arms-control.html>. 
the contrary, sanctions are used increasingly often to put international pressure on countries. In response to that, the countries subjected to such economic restrictions - Russia and China, Iran and Venezuela, Iran and Russia - have started developing cooperation between them. Thus, in parallel with the prevailing liberal economic order, there appears a quazi-order uniting the countries rejected by the liberal world.

Against this background, the great powers' geopolitical competition is getting more fierce and intense. The United StatesChina relations are heading towards confrontation. The COVID-2019 pandemic has considerably accelerated this process. Quite possibly, the spring of 2020 marked a point of no return on Washington and Beijing's way to confrontation. The trend towards the emergence of a new United States-China bipolarity in the international relations is prevailing. This bipolar structure is significantly different from that of the 1940s-1980s. The mutual polarity of the United States and the PRC is limited. Economically, the countries are still competing within a common global capitalist system. There are ideological and political differences between them, but they are mitigated by the general pragmatism of the Chinese leadership. So far, the military standoff between the two countries has not become the central element of their confrontation.

It should be noted that at the present stage the United StatesChina bipolarity has not split the world into opposing blocs, as it was the case during the Cold War. The United States' European and Asian allies gravitate to Washington, depend on it in military and political matters, as well as in ensuring security, but at the same time they are forging mutually beneficial trade and economic ties with Beijing, which they are reluctant to cease. The majority of these states do not perceive China as a threat to their security. On the other hand, neither the United States-led alliances, nor China's partnerships have evolved into blocs. The third countries are reluctant to follow their leaders and partners to that extent. Their practical policy is driven by national interests, while their solidarity with an ally or a partner is far from unconditional. This situation became obvious during the United States and Iran standoff in January 2020. 
China has virtually no formal allies. The depth and degree of institutionalization of Beijing's political influence on the states that depend on it (Pakistan, Cambodia, etc.) can be hardly compared so far with that of the United States. At the same time, China has been gradually expanding the scope of its geopolitical interests, taking preparatory steps for shaping a belt of friendly countries, first and foremost neighbouring Asian countries. However, China has opted for a different course of action as compared with the European countires and the United States. That is why Beijing does not occupy the place in the international arena vacated by Washington.

Russia is China's strategic partner. The two countries' relations not merely retain their positive dynamics, but show an increase in it. It is not the political and economic pressure put on Russia and China by the United States that has brought them closer together, but it does contribute to the strengthening of their cooperation in a number of areas ranging from energy to defense. At the same time, it is evident to both sides that the rapprochement between Russia and China has its limits. Despite the difference in the total national strength, China and Russia perceive themselves as great powers, the fact that excludes any of them from subordinating to the other, even within a friendly alliance. Thus, Sino-Russian defensive alliance against the United States is only possible in one case - let us hope that it is purely hypothetical - the United States simultaneous military aggression against both of them.

The pandemic has put Russian-Chinese relations to the test. It has highlighted the priority of national interests for both countries. At the same time, it has demonstrated the stability of their bilateral relations - the countries has managed to limit the number of mutual claims, strengthened their economic relations, showed their political solidarity, and reaffirmed their partnership. Alongside with that, an opinion has started spreading in Russia that the safe limits of the rapprochement with China have already been reached, that Russia cannot succumb to China's influence, and that it would be dangerous to get involved in the United States-Chinese conflict on Beijing's side. As for China, it has become all the more convinced that it will have to face the situation with the United States single-handedly. 
Therefore, as a result of the United States-China confrontation, Russia is faced with the challenge of preserving the balance in the new bipolarity. Thus, the situation of a standoff with a stronger opponent, the United States, appears to be easier and more familiar than that of maintaining a balance with a stronger partner, the PRC. At the same time, however, the escalation of relations between Washington and Beijing to confrontation opens up certain opportunities to Russia. That would not mean that the United States' focus has shifted from the RF to the PRC (its policy targets both countries), but rather because a relatively increased reliance of China, subjected to intense pressure by the United States, on Russia.

China's increased reliance on Russia, first and foremost, in such matters as military technology, enables Russia to partially compensate the growing imbalance in its trade and economic relations with China. In addition, a dramatic tightening of the United States policy towards the PRC makes China appreciate more the political and information support provided by Russia, which is more experienced in matters of international confrontation. The United States-Russian relations have been characterized by confrontation since the mid-2010s, and there are little grounds to believe that the countries will manage to overcome it either in the short, or even in the medium term.

Retreating, in general, from the Pax Americana, the United States makes increasing efforts to exert pressure on Russia and China and limit their international influence (the Department of State T-paper). ${ }^{3}$ At this stage Washington intends not to protect the United States-led global system, but rather to increase the military strength of the United States itself while weakening its adversaries. Beijing's readiness to make considerable concessions to Washington and Russia's attempts at a new reset in its relations with the United States in order to counter the common enemy, the infection, are deliberately ignored by

\footnotetext{
${ }^{3}$ Ford, Ch. A., 'Competitive Strategy vis-à-vis China: A View from the "T-Suite"”, Arms Control and International Security Papers, vol. 1, no. 6, 11 May 2020

$<$ https://www.state.gov/wp-content/uploads/2020/05/T-paper-series-6-Strategiccompetition.pdf>.
} 
Washington. It pursues a policy of double deterrence vis-à-vis these two countries and strives to use all its financial, economic, and technology advantage over them.

The confrontation between the United States and the two great powers is not a reissue of the Cold War scenarios. This is a new reality that still lacks a generally accepted term. Some call it a hybrid war, stressing that a wide range of tools - economic, financial, technological, and informational - is used in the conflict. The use of instruments of military force are not merely excluded, they are being built up. In the minds of politically aware Americans, China and Russia have been established as the main adversaries of the United States. The standoff between Washington and Beijing has been acquiring clearer militarypolitical dimension. The problem of nuclear deterrence has come to the fore for both countries. The tension in the Taiwan Strait and the South China Sea will apparently be increasing thereby posing threat to international peace.

The pandemic has affected all the countries. In absolute terms, every country has become weaker, but to a different degree. China appears to have survived the pandemic much better than the United States has. It is true, it was, and not by accident, the source of the infection. China let the infection emerge, yet its political system proved to be capable of containing its spread through tough measures. Chinese political and social culture contributed to the unity of the people and the government. China has good prospects for quick economic recovery. New challenges, in this regard, encourage further development. China's humanitarian diplomacy uses this crisis to further expand Beijing's international influence.

The United States, on the contrary, has demonstrated the ineffectiveness of its public health system in the situation of the pandemic, as well as chaos in its decision-making, especially at the top level, and adeep political, social, ideological, and cultural divide in its society. Its social issues and a high level of property and social inequality exacerbated. Whatever the outcome of the presidential election, the social and political controversy in the United States will persist and, possibly, aggravate. 
In the current situation of hostile bipolarity between the United States and China, it is essential that Russia enhances its economic, technological, social, political, and moral base as society, state, and country. It becomes pivotal that the elite should take a qualitative step forward and transform into a genuinely national group of leaders. That may prove to be impossible without major political and social changes. Alternatively, Russia will gradually decline and eventually collapse.

Russia's foreign policy should be aimed at strengthening its position through building relations with other centres of power in Greater Eurasia, including Germany / France / Europe in the west, India in the south, and Japan in the east, rather than through making pointless attempts at establishing a bloc of states of the former USSR. Russia may use these ties, and its partnership with China, as footholds and external sources of its future economic, scientific, and technological development.

Given the way the international situation is developing, one has to act strategically. Neither the initiatives to hold major summits - be that a Victory Day Summit in Moscow or a UN Security Council Summit nor the widely advertised humanitarian campaigns (however reasonable and helpful they might be) represent a strategic course of action aimed at strengthening Russia's geopolitical situation in the future bipolar world. However, the challenge is real and calls for an adequate response. No response or any delay will have major negative consequences. 


\title{
2. STRATEGIC ARMS CONTROL: CHALLENGES AND OPTIONS
}

\author{
Alexey ARBATOV
}

Against a background of the COVID-19 pandemic, the arms control system, builtduring the previoushalfcentury, is continuing to disintegrate. Following the abrogation of the Intermediate-Range Nuclear Forces (INF) Treaty in 2019, no steps are being considered for prevention of a new arms race with medium-range missiles. The discussion between the United States and Russia about extending the 2010 New Strategic Arms Reduction Treaty (New START) beyond its February 2021 expiration date has stagnated. As a direct effect of the pandemic, on-site inspections, which are a key element of the New START verification regime, have been interrupted. The Review Conference of the Nuclear Non-Proliferation Treaty (NPT) in New York, scheduled for AprilMay 2020, has been postponed until next year. The Treaty on Open Skies was abrogated by the May 21, 2020 decision of the United States. ${ }^{1}$ The Comprehensive Nuclear-Test-Ban Treaty, which is not ratified by the U.S.A., China, and some other nuclear powers, but observed by all of them, might be in line for discarding by Washington in the very near future.

Meanwhile, a new cycle of the nuclear and advanced conventional arms race is gaining momentum. Against a background of the collapse of the nuclear arms control regimes, this arms race will inevitably exacerbate the political tensions among the great powers, creating a higher probability of an armed conflict and the ensuing risk of nuclear escalation. If this were to happen, even the current crisis caused by the pandemic would look like a minor inconvenience.

1 'On the Treaty on Open Skies', Press Statement by Michael M. Pompeo, Secretary of State, 21 May $2020<$ https://www.state.gov/on-the-treaty-on-open-skies/>. 
That is the reason why there is no justification for ignoring or postponing efforts to overcome the current arms control deadlock. The following article is an attempt of systemic analysis of the current knot of strategic problems and misperceptions.

\section{Extending New START}

The most urgent task is addressing the strategic arms control issues in the remaining months before the expiration of the New START Treaty in February 2021. The reason to extend it (according to its Article XIV.2 ${ }^{2}$ ) is not just to retain the transparency provided by the treaty's verification regime, as valuable as it is. ${ }^{3}$ What is still more important is to provide additional time to work on a follow-on treaty.

In the history of strategic arms control, there were episodes when expiration or non-ratification of a former treaty had happened before a follow-on treaty was concluded. ${ }^{4}$ However, in the past, this had happened against a background of the virtually uninterrupted U.S.Soviet strategic arms control negotiations and temporary agreements or treaties which were not finalized (like the 1976 Vladivostok accord, 1993 START II, 1997 START III framework agreement, or 2002 SORT). Incidentally, nowadays New START may expire after a ten-year pause in this dialogue and reviving this process may take many years, during which an uncontrolled arms race would be gaining momentum defying the efforts of diplomats.

\footnotetext{
2 This article provides for a possibility to extend the Treaty once for up to 5 years by consent of the two parties.

3 See an excellent article by the chief U.S. negotiator of the New START: Gottemoeller, R., 'The New START Verification Regime: How Good Is It?', Bulletin of the Atomic Scientists, 21 May $2020<\mathrm{https}$ ///thebulletin.org/2020/05/ the-new-start-verification-regime-how-good-is-it/>.

4 For example, SALT I agreement expired in 1977 before SALT II was signed in 1979. The latter was never ratified and the next START I Treaty was signed only in 1991. The New START was signed in 2010 - three months after expiration of the START I Treaty.
} 
The latest U.S. position on this issue is that extension, just like any START follow-on treaty, is conditioned on China's participation. Russia rendered support to China's rejection of the U.S. proposals to join any new version of the INF or START follow-on treaties 5 .

In fact, China's participation in the New START extension would contradict its Article XIV.2, which deals with only two parties and says, "If either Party raises the issue of extension of this Treaty, the Parties shall jointly consider the matter." Hence, legally, before joining the New START extension, China would have to formally sign and ratify the Treaty. Furthermore, China would have to accept the New START verification regime, including exchange of information and on-site inspections. Regarding the two superpowers, this regime is designed to make sure they observe the Treaty limitations - primarily on delivery vehicles and warheads. China would stay well below both ceilings, and so this verification regime would be largely irrelevant to its compliance with the Treaty.

Moreover, joining New START would serve as legalization and encouragement of China's building up its strategic nuclear forces to the New START ceilings of 800 strategic missiles and bombers and 1,550 warheads (thus increasing its current forces in the two dimensions by 5 and 10 times respectively ${ }^{6}$ ). Obviously, neither the U.S.A. nor Russia would welcome this prospect. What all this would mean is not just extending the Treaty in trilateral mode, but renegotiating the most important parts of the Treaty - virtually elaborating a new treaty. This would take much longer time than left till its expiration in February 2021 or even than the 5-year extension period permitted by the Treaty. The only intervention which might help the New START extension

\footnotetext{
5 Plenary Session of the Eastern Economic Forum, 5 Sep. $2019<\mathrm{http}$ ://kremlin.ru/ events/president/news/61451> [in Russian].

${ }^{6}$ Although China keeps its current nuclear strategic forces in secret, most foreign experts estimate their number at around 150 land- and sea-based ballistic missiles (China does not have heavy bombers) and slightly more warheads, since some of the missiles are equipped by the MIRV systems (multiple independently targetable reentry vehicles).
} 
from the Chinese side is its official commitment to join the process of strategic arms limitation in the very near future in appropriate time and under acceptable conditions.

Thus, the New START extension should remain a U.S.-Russia bilateral deal, including the mutual understanding that the new Russian Avangard boost-glide system and Sarmat heavy ICBM must be recognized as subjects of all treaty provisions.

Issues related to New START follow-on could be settled during this extra time. Before engaging China, it would be logical to agree in principle on the scope and parameters of further U.S.-Russian arms reductions, relying on the half-century bilateral experience of conducting these negotiations. Only after that a new and controversial question of China's participation may be addressed.

\section{Next START bilateral outline}

The nuclear forces of China, the United Kingdom, and France would not be limited in the next few years, which might be required to reach the next U.S.-Russian bilateral agreement on strategic arms reduction. Such agreements are usually designed for at least a ten-year term and have to take account not only of each other's forces developments, but also of the projected nuclear potentials of other states.

This is the reason why further deep cuts of the strategic forces of the two major powers (following the manifold reductions since 1991) are presently not an urgent or most important goal and may be safely postponed. The follow-on ceilings may be lowered symbolically, say, by just about 100 deployed delivery vehicles and warheads (i.e. down to 600 and 1400 respectively). Far more imperative is the scope of the next agreement, the main goal of which should be enhancing strategic stability and taking care of newly emerging destabilizing weapon systems and technologies.

These technological novelties are well known to the expert community. First of all, those are various long-range high-precision subsonic conventional systems, which are capable of hitting targets 
previously accessible only to nuclear weapons. ${ }^{7}$ The next generation of still longer range hypersonic high-precision weapons is being developed and deployed by the U.S.A., Russia, and China: hypersonic boost-glide $^{8}$ and aero-ballistic systems, which may be armed with nuclear or conventional warheads. ${ }^{9}$ Secondly, there is also a rapid expansion of cyberwarfare technology, development of space arms, and modernization of missile defense systems, which are gaining offensive (i.e. anti-satellite) capabilities ${ }^{10}$.

Many offensive weapons have dual use and are impossible to be distinguished from nuclear ones until an actual impact. Such weapons and automated command-control and information systems blur the "nuclear threshold" and may trigger an uncontrollable escalation of a local conflict or even military accident in a time of crisis. ${ }^{11}$ From

7 For instance, U.S. Tomahawk ship-launched (BGM-109) cruise missiles, air- and ground-launched missiles (AGM-84, AGM-158B, JASSM-ER, ARRW). Russian analogues are non-nuclear 3M-14 Kalibr sea-launched missiles, and Kh-55SM, Kh-555, and Kh-101 air-launched missiles, and 9M728 Iskander and 9M729 Novator ground-launched missiles.

8 Acton, J., Silver Bullet? Asking the Right Questions about Conventional Prompt Global Strike, Carnegie Endowment for International Peace, Washington, DC, 2013.

9 The U.S. is testing such systems under its Prompt Global Strike program: Army's Long-Range Hypersonic Weapon, Navy’s Conventional Prompt Strike, Air Force the AGM-183 Air-Launched Rapid Response Weapon. In addition to that, the U.S. is testing the X-51A WaveRider hypersonic missile for heavy bombers. Russia is ahead of the United States in developing a nuclear-powered intercontinental cruise missile - Burevestnik (Skyfall). It's also deploying the Avangard hypersonic boostglide vehicle that is carried by the UR-100UTTKh (SS-19) deployed in 2019.

${ }_{10}$ For instance, Russian Nudol missile defense systems and the S-400 and S-500 missile systems, and the U.S. ship-based Aegis SM-3 missile defense system.

${ }^{11}$ An interview with S. Shoygu. "Sergey Shoygu Told How the Russian Army Was Saved", Moskovskiy Komsomolets, 22 Sep. $2019<$ https://www.mk.ru/ politics/2019/09/22/sergey-shoygu-rasskazal-kak-spasali-rossiyskuyu-armiyu.html> [in Russian]. 
the other flank the "nuclear threshold" is eroded by concepts and means of conducting a limited nuclear war and introduction of strategic and tactical low-yield nuclear warheads ${ }^{12}$.

These innovative weapons systems and technologies are eroding strategic stability, which was at the core of the 1991-2010 START treaties. The concept of strategic stability was formulated in the 1990 Soviet-American declaration ${ }^{13}$, which defined strategic stability as a state of a strategic relationship which removes incentives to launch a first nuclear strike. At that time, such an incentive was perceived as the ability to launch a disarming (counterforce) nuclear strike with the goal of avoiding a retaliatory strike or reducing its consequences to an acceptable level. Such a capability in a crisis might encourage nuclear aggression or pre-emption. During 1991-2010 the U.S.-Russian strategic arms agreements were tangibly affected by that concept of strategic stability and drastically decreased mutual first strike capabilities in the course of deep arms reductions.

Nowadays the concept of strategic stability must not be discarded, but should be adapted to the new technical and strategic realities, which has not been done since 1990. In particular, the list of incentives for a first nuclear strike should be broadened to include not only a possibility of a massive counterforce attack, but also a threat of conventional counterforce strikes with long-range non-nuclear weapons. Furthermore, the formula of strategic stability should address the threat of a limited nuclear use, which might be aimed at preventing opponent's victory in conventional war or at solidifying one's own initial gains in such a war. Strategic arms control can contribute to strategic

12 For instance, the U.S. is developing Trident II submarine-launched ballistic missiles with low-yield warheads (W76-2), aircraft-launched long-range cruise missiles (LRSO type), guided variable-yield gravity bombs (B61-12), and new sea-launched nuclear-armed cruise missiles. Nuclear Posture Review 2018, Office of the Secretary of Defense, Department of Defense, Feb. 2018, p. $23<$ https://media.defense.gov/2018/ Feb/02/2001872886/-1/-1/1/2018-NUCLEAR-POSTURE-REVIEW-FINAL>.

13 Soviet-United States Joint Statement on Future Negotiations on Nuclear and Space Arms and Further Enhancing Strategic Stability, 1 Jun. $1990<$ https:// www.presidency.ucsb.edu/documents/soviet-united-states-joint-statement-futurenegotiations-nuclear-and-space-arms-and $>$. 
stability by limiting some weapon systems associated with such concepts. Consequently, the modernized concept of strategic stability should now be formulated as "a state of strategic relationship which removes the incentives for any use of nuclear weapons." Such incentives are the old one - a threat of a massive disarming nuclear strike, and a new one-conventional counterforce strikes and limited use of nuclear weapons in local or regional conventional wars.

Dealing with new threats to strategic stability in the follow-on START treaty requires that the long-range (i.e. more than $600 \mathrm{~km}^{14}$ ) air-launched nuclear and conventional cruise and hypersonic missiles and nuclear gravity bombs are included under a common warhead ceiling, and that they be counted according to the actual loading of the heavy bombers. In the past, air-launched missiles were counted under the warheads ceilings in the 1991 START I and 1993 START II Treaties. ${ }^{15}$ Limits on strategic delivery vehicles and warheads should also cap the innovative weapon systems: ground-based intercontinental cruise missiles and long-range autonomous underwater drones, as well as land- and sea-based boost-glide hypersonic systems with ranges defined similar to what was in the SALT and START treaties (e.g. landbased missiles with ranges greater than 5,500 km and sea-based missiles with ranges greater than $600 \mathrm{~km}^{16}$ ). Such weapons should be limited regardless of whether their warheads are nuclear or conventional.

Verification of the limitations on ground-launched long-range cruise missiles (like Russian Burevestnik) is possible using the former INF Treaty verification measures. ${ }^{17}$ Sea-launched cruise missiles (SLCMs) and boost-glide systems present a much more serious challenge, but the initial solution might be to extend confidence-building measures

\footnotetext{
14 The $600 \mathrm{~km}$ range was set to define strategic ALCMs and heavy bombers equipped with such weapons for SALT II (1979) and START I treaties.

15 Only the 2010 New START Treaty adopted liberal count rules for each bomber: one delivery vehicle $=$ one warhead, although in reality, it could carry up to 20 missiles.

16 Such criteria were set in the SALT I (1979) and START I (1991) treaties.

17 Arbatov, A., 'What Makes the U.S. Withdrawal from the INF Treaty Dangerous to Russia', Carnegie Moscow Center, 23 Oct. $2018<$ https://carnegie.ru/ commentary/77543> [in Russian].
} 
to these missiles, including exchange of numerical data (as was agreed under START I). Boost-glide ground-based and air-launched hypersonic missiles (the Russian Avangard system and the systems developed under the U. S. Conventional Prompt Global Strike Program) would not pose a serious problem. Boost-glide land-based and sea-based systems may be verified like land- or sea-based ballistic missiles. Hypersonic aero-ballistic missiles limitation should be verified on heavy bombers together with other cruise missiles and nuclear gravity bombs.

In this way, the most destabilizing long-range strategic systems which blur a clear line between conventional and nuclear warfare would become subject to verifiable arms control. Indirectly, their numbers would be limited, since under common ceilings they would "compete" with the number of proven and reliable nuclear-tipped strategic ballistic missiles. The latter would also have to be reduced to allow for groundand air-launched cruise missiles, hypersonic boost-glide and aeroballistic missiles, and underwater nuclear drones to be counted under the overall limit.

Sea-based and air-based disposable unmanned (robotic) longrange weapon systems, including those equipped with artificial intelligence, should be controlled like all strategic weapons - according to the class of delivery vehicles and maximum tested range rather than their guidance systems. For instance, Russia's Poseidon unmanned underwater vehicles can be verifiably controlled just like sea-launched ballistic missiles.

The subject of space weapons is not a new one; it has been around for decades. At present, the U.S.A., Russia, China, and India have already tested anti-satellite weapons (ASAT) that incorporate nonnuclear missiles, close encounters by satellites and electronic warfare. It is possible to partially weaken the threat by prohibiting further tests of any anti-satellite systems against real targets in space. ${ }^{18}$ This would

18 Arbatov, A., 'Arms Control in Outer Space: The Russian Angle, And a Possible Way Forward', Bulletin of the Atomic Scientists, 2019, vol. 75, № 4 (Special issue: 'Space: Military frontier or arms control opportunity?'), pp. 151-161. 
significantly increase the survivability of the key U.S. and Russian missile attack early warning satellites and slow down the dangerous proliferation of space debris.

Agreeing and verifying prohibitions on cyberwar systems seem an unreachable goal at this time. The most that can be hoped for is a dialogue between the United States and Russia on a mutual commitment (even if unverifiable, like the past commitment on nontargeting missiles on each other) not to launch cyberattacks on each other's strategic information and command-control systems. There is a mutual interest in preventing an inadvertent exchange of nuclear strikes, as well as jointly coping with the threat of provocation by third countries or cyberterrorists.

The proposed model of the START follow-on would not address a number of potentially destabilizing weapon systems and technologies: anti-missile defense, space arms, cyber warfare, directedenergy weapons, tactical nuclear weapons, and a great variety of drones with artificial intelligence. Those systems and technologies cannot be addressed immediately, either technically or diplomatically. However, it does not mean that there is no sense in addressing weapons and technologies, which may be managed in the near future by arms control under the follow-on START treaty for the sake of sustaining strategic stability. Eventually, the exotic weapons might be taken care of by future negotiations, provided that the first steps outlined above are urgently taken to prevent the final collapse of the arms control regimes.

\section{Preserving the core of the INF Treaty}

Besides extending New START, the top priority is to salvage the core provisions of the INF Treaty. In 2019, the United States announced it would withdraw from the treaty due to the alleged Russian violations (deployment of 9M729 Novator cruise missiles, called SSC-8 in the U.S.A.) and the massive build-up of such weapons by China (which was not a party to that agreement). Since the U.S.A. plans for possible 
new missile deployments in Asia are linked to Chinese programs, it is up to those two powers to search for possible mutual accommodation, however difficult this presently looks.

In Europe, U.S. and Russian medium-range missile deployments should be avoided at all costs. In 1987, the INF Treaty was the first and historically the most radical step to ending the Cold War and the nuclear arms race. Besides having dealt with the threat of medium and shortrange missiles, it opened the way to the first radical strategic arms reduction treaty (START I), and together with the Treaty on the reduction of conventional forces in Europe (CFE) encouraged the reduction and elimination of tactical nuclear arms in Europe by an order of magnitude.

The new medium-range missiles in Europe would be highly destabilizing by inducing mutual planning for pre-emptive strikes. Apparently this prospect was implied in a statement by Valery Gerasimov, Chief of the General Staff of the Armed Forces of the Russian Federation, General of the Army, when he said, "The policy of Western 'partners' makes us respond to a threat with a threat, by planning in advance to deliver strikes against the decision-making centres and launchers for employment of cruise missiles against targets at Russian territory." 19

Such developments would also block any possibility of continuing strategic arms control cooperation even if New START is extended after its expiration on February 2021. The reason is that American intermediate-range missiles in Europe would be perceived by Moscow as threatening a decapitating and disarming strike on Russia's strategic deterrent, as was Russia's concern in the early 1980s. This perceived threat had been blocking the progress at the START I negotiations until the breakthrough was achieved on the INF Treaty in 1987. Moreover, new intermediate-range missiles deployment would stimulate Russia and NATO to build up their conventional and tactical nuclear forces.

In January 2019, Russian missiles, perceived by the United States and NATO as a treaty violation, were shown to foreign military representatives to demonstrate that they technically could not fly further

19 Gerasimov, V., 'The General Staff is Planning Strikes', Voenno-Promyshlennyi Kur’er, № 9, 12-18 Mar. 2019, p. 6 [in Russian]. 
than $500 \mathrm{~km}$. NATO states declared that the systems displayed were different from the missiles in question. A temporary deal on this issue, until a time when the U.S.A. and China reach some compromise, should be based on Russia's proposal to NATO states made in late 2019 to agree on a moratorium on deployment of medium-range missile systems in Europe. In order to fortify this deal, the two sides should jointly develop additional means of verification, using confidence-building measures and on-site inspections, to make sure that the missiles deployed in the Russian regular units are the same as those demonstrated in Moscow in 2019.

For its part, Moscow claims that the U.S. missile defense launchers for the Standard SM-3 interceptors deployed in Romania and Poland could be used to host and launch offensive Tomahawk sea-based cruise missiles. Those are deployed on U.S. surface ships in the same Mk-41 launchers as the Standard antimissiles. This concern could also be resolved by agreed transparency and on-site inspection provisions or stopped before technically settled.

$$
* * *
$$

During the last three decades after the end of the Cold War, the changes in the global nuclear balance have not been revolutionary. During this time the share of the two nuclear superpowers in the aggregate quantity of the world's nuclear weapons was reduced from 98 to 91 percent (while the whole arsenal was cut from 46,000 to 14,000 weapons).$^{20}$ Still, it would be wonderful if other nuclear states adopted the restrictions and subsequently reductions on nuclear weapons after thirty years of such steps undertaken bilaterally by Russia and the United States.

At the same time, the fifty years' history of the negotiations have demonstrated that such steps are only taken if states perceive tangible improvements in their security through limitation and reduction of

20 The calculations are based on: SIPRI Yearbook 1990: World Armaments, Disarmament and International Security, Oxford University Press, 1991, pp. 3-54; SIPRI Yearbook 2018: Armaments, Disarmament and International Security, Oxford University Press, 2019, pp. 235-287. 
comparable weapons by the other side. Besides, no state would agree to legally validate the opponent's military advantage, which implies some arms balance of approximate equality as the starting and finishing points of agreed limitation and reduction. Finally, arms control treaties should be reliably verified by ways and means, which determine the nature of possible limitations.

Hence, it is up to the United States and Russia to develop a proposal that would interest China with regard to agreements on both medium-range missiles and strategic arms. The parties may also have to engage the United Kingdom and France, since Russia and China would certainly demand inclusion of the two nuclear-weapon states. There would be no reason to exclude them, in particular in view of the obligation of the five nuclear-weapon states under the Nuclear NonProliferation Treaty's famous Article VI.

Advocates of this idea must realize that it requires more than simply revising the current positions of China or other third states. The two nuclear superpowers would have to pay a much higher price for this: both strategically and politically. So far, it's not at all clear whether the two superpowers comprehend this dilemma or when they will be ready to make major political and strategic concessions for the sake of transition to a multilateral arms control format.

In the meantime, U.S.-Russian bilateral arms control should continue and stay at the core of international security, even if many problems cannot be resolved quickly and summarily. The United States and Russia should urgently start negotiations on the START followon treaty after extending New START by five years (or less if the new treaty is concluded earlier) and after agreeing on a verifiable moratorium on intermediate-range missiles deployment in Europe. Eventually, it would be easier to search for ways to control the newest instruments of war and engage third countries in the nuclear disarmament process relying on the framework of continuing arms control, while it would be unthinkable in its absence. 


\section{NPT PROBLEMS IN LIGHT OF INCREASED COMPETITION IN THE GLOBAL MARKET OF NUCLEAR MATERIALS AND TECHNOLOGIES}

\section{Anatoly DIAKOV}

Since its advent in the early 1950s, nuclear energy went through different stages of development and crises. The 1986 Chernobyl accident prompted states to lose interest in nuclear energy and abandon the construction of new nuclear power plants (NPPs). However, in the early 2000s, the number of potential consumers of nuclear energy increased again, which created a discourse around the so called "nuclear renaissance." The 2011 Fukushima nuclear accident once again had resulted in fading interest in nuclear energy (notably, Germany and Japan postponed or abandoned a large number of their nuclear projects) and at the same time necessitated implementation of new design and technical measures to improve the safety of NPPs. Share of nuclear energy in electricity production decreased from $17.5 \%$ in 1996 to $10.2 \%$ in $2018 .{ }^{1}$

It is believed today that global nuclear energy got over the "Fukushima syndrome." Despite a certain level of stagnation in nuclear industry of the United States and Europe, the 2019 Nuclear Fuel Report prepared by the World Nuclear Association (WNA) provides estimates that installed nuclear generation capacity is expected to increase, from 390 GWe by early 2020 to $462 \mathrm{GW}(\mathrm{e})$ by $2030 .^{2}$ According to the WNA, there is a plan to erect 110 NPPs worldwide, with 67 in Asia, which indicates a shift in demand for nuclear energy from Western to Asian and Middle Eastern countries.

\footnotetext{
1 'Energy, Electricity and Nuclear Power Estimates for the Period up to 2050', IAEA, VIENNA, $2019<\mathrm{https}$ ://www.developmentaid.org/api/frontend/cms/ uploadedImages/2019/09/19-00521_web.pdf>; Ritchie, H., and Roser, M., 'Energy', Ourworldindata.org, Jul. $2018<$ https://ourworldindata.org/energy>.

2 'World Nuclear Association sees upturn in uranium demand', World Nuclear News, 5 Sep. $2019<$ https://world-nuclear-news.org/Articles/Nuclear-fuel-reportsees-upward-trend $>$.
} 
According to the IAEA PRIS database, at the beginning of 2020, 54 reactors were under construction around the globe. ${ }^{3}$ Only eight of these are being built in Western Europe, the United States and Japan, other 32 power reactors are under construction in Bangladesh, South Korea, Pakistan, India, China, Iran, the UAE and Turkey (18 of them in India and China). In the near future, Uzbekistan, Egypt and Saudi Arabia also intend to begin construction of NPPs.

As demand for nuclear energy shifts from Western countries to newcomers in the East, so do the major suppliers in the international nuclear technology market, with China and Russia increasingly assuming the supplier role. This situation, in turn, causes concern among Western countries, mainly in the United States. ${ }^{4}$

The proliferation of nuclear technologies and materials aggravates the risks for the nuclear nonproliferation regime, especially given the fact that the technologies related to the production of weaponsgrade nuclear materials and fuel for NPPs are largely the same. Foremost among these risks are undoubtedly those associated with the acquisition of technologies for the production of weapons-grade fissile materials highly enriched uranium and plutonium (acquiring such technologies is the main technical obstacle to creating nuclear weapons. Specifically for this reason, it is now generally recognized that the greatest risks to the nuclear non-proliferation regime come from the proliferation of sensitive nuclear fuel cycle (NFC) technologies - in particular, uranium enrichment and/or reprocessing.

\footnotetext{
3 'Reactor Status Reports. Reactors Under Construction', PRIS $<$ https://pris.iaea. org/PRIS/WorldStatistics/UnderConstructionReactorsByCountry.aspx>.

${ }^{4}$ DiChristopher, T., 'The US is losing the nuclear energy export race to China and Russia. Here's the Trump team's plan to turn the tide', CNBS, 21 Mar. $2019<\mathrm{https} / /$ www.cnbc.com/2019/03/21/trump-aims-to-beat-china-and-russia-in-nuclearenergy-export-race.html>.
} 


\section{Nuclear fuel cycle and nuclear energy market at various stages of NFC}

Most modern energy reactors use fuel that has uranium U-235 as the main component. A number of countries, for example, France and Japan in addition to uranium fuel also produce and use MOX fuel that consists mainly of plutonium.

Natural uranium contains approximately $0.7 \%$ U-235 (i.e., uranium isotope with mass number 235), and $99.3 \% \mathrm{U}-238$. Uranium with U-235 concentration of greater than $20 \%$ can be used to create a fairly small explosive device. If uranium has more than $90 \%$ of $\mathrm{U}-235$, it is classified as a weapon-grade material and is used in nuclear weapons. The production of uranium with U-235 concentration of more than normally found in nature requires the use of sophisticated isotope separation technology.

Plutonium is virtually unknown in nature - it is an artificially created fissile material. It is produced in nuclear reactors filled with fuel made of natural or low-enriched uranium that is rich in neutrons.

The nuclear fuel cycle is commonly divided into two stages: front-end and back-end. The former includes the extraction of uranium ore, the production of uranium concentrate $\mathrm{U}_{2} \mathrm{O}_{6}$ and the process of its conversion, which leads to the production of uranium hexafluoride $\mathrm{UF}_{6}$. Uranium hexafluoride arrives to the uranium enrichment plants, where the enrichment process is carried out using the U-235 isotope.

The world's leading technology for uranium enrichment uses highly efficient gas centrifuges. The fabrication of fuel-grade uranium via centrifugation takes approximately 15 enrichment cycles, and about 40 cycles are required to produce weapon-grade uranium. The centrifuge method poses rather serious risks to the nonproliferation regime, both due to the high enrichment level at each enrichment cycle and because the clandestine centrifuge enrichment plants are difficult to detect due to their low energy consumption. 
The final NFC stage includes management of spent (irradiated) nuclear fuel (SNF). SNF contains mainly 1\%-enriched uranium, as well as plutonium and decay daughter products. While latter are sent for burial, uranium and plutonium can be used again in the production of nuclear fuel.

Reprocessing spent nuclear fuel also poses a risk to the nonproliferation regime since it results in the production of plutonium. From technical perspective, fuel reprocessing is not a sensitive technology; however, its practical implementation requires the knowhow to create reliable protection against radiation, the use of remote manipulators and is therefore cost-intensive. In addition, the chemical reprocessing of spent nuclear fuel is difficult to carry out in secrecy, since the radioactive Krypton- 85 released from reprocessing activity can be easily detectable.

\section{Market conditions at various stages of the NFC}

Uranium hexafluoride production. Over the past few years, the market for the conversion of uranium to uranium hexafluoride has been oversupplied due to lower requirements for conversion and accumulation of uranium hexafluoride supplies. As a result, the annual production volume is currently lower than the needs and available production capacities of facilities that are not fully utilized.

Uranium Enrichment. The list of countries with uranium enrichment facilities and their capacity is presented in Table 1.

It is estimated that providing global nuclear energy with fuel with $5 \%$ enrichment in U-235 requires about 50 million SWU/year. ${ }^{5}$ As can be seen from Table 1, uranium enrichment capacities available in the world are significantly higher. Therefore, even if the installed capacity of the global nuclear energy industry grows in the next 5-10 years along with the demand for enrichment services, the currently

5 'Uranium enrichment', WNA, May $2020<$ https:/www.world-nuclear.org/ information-library/nuclear-fuel-cycle/conversion-enrichment-and-fabrication/ uranium-enrichment.aspx $>$. 
Table 1. Uranium enrichment enterprises, by country (at the end of 2019)

\begin{tabular}{llc}
\hline Country & Factory & Capacity, (1000 SWU/year) \\
\hline Brazil & Resende & 50 \\
United Kingdom (Urenco) & Capenhurst & 4,900 \\
Germany (Urenco) & Gronau & 4,100 \\
India & Ratnahalli, Karnataka & 4,5 \\
Iran & Natanz, Fordou & $6,7+0,6$ \\
China & Hanzhong, Lanzhou & $5,700-7,000$ \\
Netherlands (Urenco) & Almelo & 5,400 \\
Pakistan & Kahuta & $15-20$ \\
& Novouralsk, Seversk, & \\
Russia & Zelenogorsk, Angarsk & 24,600 \\
USA & LeaCounty, NM & 6,400 \\
France & Tricastin & 7,500 \\
Japan & Rokkasho-mura, NingyoToge & 1,250 \\
DPRK & Yongbyon & $8-16$ \\
Total & & $\mathbf{6 1 , 0 0 9 . 8}$ \\
\hline
\end{tabular}

Sources: International Panel on Fissile Materials. Enrichment Facilities, 17 May 2020 $<$ http://fissilematerials.org/facilities/enrichment_plants.html $>$; World Nuclear Fuel Facilities $<$ https://www.wise-uranium.org/efac.html>; World Nuclear Association, Country Profiles $<$ https://www.world-nuclear.org/information-library/country-profiles.aspx>.

available enrichment capacities will be enough to meet demand. Under a favorable scenario, additional enrichment capacities may be required no earlier than by the end of the 2020s.

Fuel production. Nuclear fuel is supplied to consumers in the form of fuel assemblies that correspond to design characteristics and specific requirements of the respective type of reactors. Currently, three types of reactors are mainly used in the nuclear power industry worldwide: light-water reactors with a total capacity of $355.9 \mathrm{GW}(\mathrm{e})$, heavy-water reactors with a capacity of $24.6 \mathrm{GW}(\mathrm{e})$, and gas-cooled reactors with a capacity of $7.7 \mathrm{GW}(\mathrm{e}){ }^{6}$

\footnotetext{
6 'Reactor Status Reports. Reactors Under Construction', PRIS $<$ https://pris.iaea. org/PRIS/WorldStatistics/UnderConstructionReactorsByCountry.aspx>.
} 
The main suppliers of fuel for light-water reactors are the French Areva, four Japanese companies, including Mitsubishi Nuclear Fuel and Global Nuclear Fuel-Japan, three American companies - Areva Inc., Global Nuclear Fuel-Americas and Westinghouse, and the Russian company TVEL. The production capacity of these countries' facilities (9,584 tonnes per year) amounts to about $70 \%$ of the capacity of all fuel producers in the world, and the annual demand for fuel for lightwater reactors today is at 7,000 ton. ${ }^{7}$ Thus, the production capacities of fuel production facilities significantly exceed the needs. At the same time, an increase in the installed capacity of the global nuclear energy industry is expected to increase the demand for nuclear fuel.

The final stage of the fuel cycle. The final stage of the NFC includes operations for the management of spent nuclear fuel. Some countries choose to pursue the closed nuclear fuel cycle, which involves the chemical processing of spent nuclear fuel. The plutonium extracted during SNF reprocessing is used to produce MOX fuel, which is a mixture of uranium and plutonium oxides, in which plutonium is the main fissile isotope.

Light-water nuclear reactors that are currently in use are not well-equipped for carrying out effective multiple cycles of spent nuclear fuel reprocessing; therefore, the MOX fuel that they produce is generally not processed but sent for storage. Transition to a closed fuel cycle is associated with the development and implementation of commercial fast breeder reactors, which may allow for multiple cycles of spent nuclear fuel reprocessing. This would also allow to extract 50100 times more energy from uranium fuel than it is done now.

Partially closed fuel cycle is implemented today in a number of countries, including France, Japan and Russia. Apart from these states, China, Germany, India, the United Kingdom and the United States are among countries that possess the technology for reprocessing of spent nuclear fuel from civilian nuclear reactors.

\footnotetext{
7 'Nuclear Fuel and its Fabrication', WNA, May $2020<$ https://www.world-nuclear. org/information-library/nuclear-fuel-cycle/conversion-enrichment-and-fabrication/ fuel-fabrication.aspx>.
} 
Nuclear fuel reprocessing plants in France and the UK previously conducted reprocessing of spent nuclear fuel from Belgium, Germany, Italy, Spain, the Netherlands, Sweden, Switzerland and Japan. Currently, only the Netherlands sends its spent nuclear fuel for reprocessing to France. In the United Kingdom, one oxide SNF reprocessing plant was shut down in 2018, and another is expected to close in the early 2020 s.

In France, nuclear reactors annually produce about 1,150 tonnes of spent fuel. Just over 1,000 tonnes of spent nuclear fuel are sent for processing to two different reprocessing facilities, and as a result, about 10 tonnes of plutonium and 1,000 tonnes of uranium are being extracted from SNF. A significant part of the extracted plutonium is sent to the Orano Melox plant, which annually produces about 120 tonnes of MOX fuel. ${ }^{8}$

In Russia, the RT-1 plant is currently reprocessing spent nuclear fuel from VVER-440 reactors located in Russia and Ukraine.9 The extracted plutonium is sent to storage, while extracted uranium is used for fabrication of fuel for RBMK-1000 reactors.

China also sees reprocessing as an effective way of handling spent fuel and is considering the possibility of future reprocessing of its spent nuclear fuel. In 2006, the country completed the construction of a pilot spent fuel reprocessing plant at the Lanzhou nuclear fuel production facility. In 2015, it launched a demonstration plant with a capacity of 200 tonnes of spent nuclear fuel per year at the Gansu Nuclear Technology Industrial Park. ${ }^{10}$ The Chinese CNNC entered into an agreement with the French Orano on the construction of a spent

\footnotetext{
${ }^{8}$ Krikorian, Sh., 'France's efficiency in the nuclear fuel cycle: what can oui learn?', IAEA Bulletin, June 2019 <https://www.iaea.org/sites/default/files/publications/ magazines/bulletin/bull60-2/6020809.pdf $>$.

9 'SNF arrived to Chelyabinsk region from Ukraine for reprocessing', AtomInfo.ru, 29 Nov. 2019 <http://www.atominfo.ru/newsz/a0678.htm> [In Russian].

10 'China's Nuclear Fuel Cycle', WNA, Oct. $2019<$ https://www.world-nuclear.org/ information-library/country-profiles/countries-a-f/china-nuclear-fuel-cycle.aspx $>$.
} 
nuclear fuel reprocessing facility and the production of MOX fuel using French technology (it is assumed that the plant will be put to operation after 2030). ${ }^{11}$

The DPRK and Pakistan also have the technology and spent nuclear fuel reprocessing facilities. In the DPRK, the Yongbyon irradiated fuel processing facility with a capacity of 200 tonnes per year is used to process spent nuclear fuel from a gas-graphite reactor with the goal of producing weapons-grade plutonium. In Pakistan, reprocessing of spent nuclear fuel from four industrial reactors to produce weapons-grade plutonium is underway at Rawalpindi and Chashma facilities. Their estimated productivity is about 300 tonnes of SNF per year.

Market of nuclear power reactors. The most widespread in the world are water-cooled, or so-called light-water reactors, in which water is used as a moderator and coolant. Of the currently operating 449 nuclear power reactors, 370 are of this type. Of the total number of reactors under construction, 47 are of light-water type reactors.

Over the past 10 years (from 2010 to 2019), 61 reactors have been built globally (Table 2).

The international market for nuclear reactor technology suppliers is currently owned by four companies - the French Framatome (formerly Areva), the South Korean KEPCO, the American Westinghouse, and Atomstroyexport, a subsidiary of the Russian Rosatom corporation. Over the past decade, Areva and Westinghouse have built 4 reactors each in China, and the Russian Atomstroyexport has completed the construction of one reactor in Iran, 3 reactors in China, and 2 reactors in India.

Technical solutions implemented in the design of the Russian VVER-1200 reactor, as well as in the Westinghouse's AP-1000 project and Framatome's EPR, meet high safety requirements, which allows them to be assigned to the $3+$ generation reactor units. Joining France, Russia, and the United States, China has recently become another country with the technology to design and build this type of reactor.

\footnotetext{
11 MOX, Recycling Nuclear Energy <https://www.orano.group/country/china/en/ our-stories/mox-recycling-nuclear-energy $>$.
} 
Table 2. Nuclear power reactors put into operation from 2010 to 2019

\begin{tabular}{|c|c|c|c|c|c|c|c|c|c|c|c|c|}
\hline $\begin{array}{l}\text { Country / } \\
\text { Year }\end{array}$ & 2010 & 2011 & 2012 & 2013 & 2014 & 2015 & 2016 & 2017 & 2018 & 2019 & Total & $\begin{array}{l}\text { Project country/ } \\
\text { number of reactors }\end{array}$ \\
\hline Argentina & & & & & 1 & & & & & & 1 & Siemens (Germany)/1 \\
\hline India & 2 & 1 & & 1 & & & 1 & & & & 5 & India/3, Rosatom/2 \\
\hline Iran & & & & 1 & & & & & & & & Rosatom/1 \\
\hline China & 2 & 3 & 1 & 3 & 3 & 8 & 5 & 3 & 7 & 2 & 37 & $\begin{array}{l}\text { Framatome (Fr.)/4, } \\
\text { Rosatom } / 3, \\
\text { Westinghouse (US)/4, } \\
\text { CNNC+ CGN } \\
\text { (China) } / 31\end{array}$ \\
\hline $\begin{array}{l}\text { Republic of } \\
\text { Korea }\end{array}$ & f 1 & & 2 & & & 1 & 1 & & & 1 & 6 & HNP (ROK) / 6 \\
\hline Pakistan & & 1 & & & & & 1 & 1 & & & 3 & CNNC (China) / 3 \\
\hline Russia & & & & 1 & 1 & 1 & 1 & & 2 & 1 & 7 & Rosatom / 7 \\
\hline $\begin{array}{l}\text { United } \\
\text { States }\end{array}$ & & & & & & & 1 & & & & & Westinghouse / 1 \\
\hline Total & 5 & 5 & 3 & 6 & 5 & 10 & 10 & 4 & 9 & 4 & 61 & \\
\hline
\end{tabular}

Sources: Green, J., 'Nuclear Power: 2018 in review', Nuclear Monitor, Issue 871, no. 4769, 25 Jan. $2019<$ https://wiseinternational.org/nuclear-monitor/871/nuclearpower-2018-review>; PRIS, Country Statistics <https://pris.iaea.org/PRIS/CountryStatistics/ CountryStatisticsLandingPage.aspx $>$; Information Library, Country Profiles, WNA $<\mathrm{https} / / /$ www.world-nuclear.org/information-library.aspx $>$.

The experience in building ACP-1000 and ACPR-1000 reactors under license and technology from French Areva enabled Chinese specialists to master the technology and begin building reactors under their own CPR-1000 and ACPR -1000 projects.

Of the 45 reactors currently under construction in the world (Table 3), only 7 reactors are being built by companies from Western countries - France, the US and Japan, which means that the share of traditional suppliers is only slightly more than $15 \%$. Chinese and South Korean suppliers are building 18 reactors, the Russian Rosatom is constructing another 12, while India is working on five. 
Table 3. Reactors under construction, at the end of 2019

\begin{tabular}{lccl}
\hline Country & Number of reactors & $\begin{array}{c}\text { Total electric } \\
\text { power, MV }\end{array}$ & Manufacturer \\
\hline Argentina & 1 & 25 & Carem (Argentina) \\
Bangladesh & 2 & 2,160 & Rosatom (RF) \\
Belarus & 2 & 2,220 & Rosatom (RF) \\
United Kingdom & 1 & 1,630 & Framatome (France) \\
India & 1 & 500 & Bhavini (India) \\
& 4 & 2,800 & NPCIL (India) \\
China & 2 & 2,000 & Rosatom (RF) \\
& 4 & 4,598 & CGN (China) \\
Republic of Korea & 5 & 8,048 & CNNC (China) \\
United Arab Emirates & 1 & 210 & China Huaneng (China) \\
Pakistan & 4 & 5,600 & KHNP (ROK) \\
Russia & 4 & 5,600 & KHNP (ROK) \\
Slovakia & 2 & 2,200 & CNNC (China) \\
United States & 3 & 3,660 & Rosatom (RF) \\
Turkey & 2 & 880 & Rosatom (RF) \\
Finland & 2 & 2,500 & Westinghouse (US) \\
France & 1 & 1,200 & Rosatom (RF) \\
Japan & 1 & 1,600 & Framatome (France) \\
\hline
\end{tabular}

Sources: 'Reactor Status Reports. Reactors Under Construction', PRIS $<$ https://pris.iaea. org/PRIS/WorldStatistics/UnderConstructionReactorsByCountry.aspx>; press materials.

\section{Competition and control of nuclear exports}

The emergence of new suppliers in the global nuclear technology market, such as China and South Korea, and the diminishing role of traditional suppliers from Western countries, along with the simultaneous growth of consumers from the regions of the Middle East and Asia, leads to increased competition in this market. Innovative nuclear energy is one of the fields that generates competition, particularly as it relates to the development and commercial supply of low-power modular reactors 
(small modular reactors). ${ }^{12}$ Competitive rivalry in the nuclear market is determined not only by market factors, such as the quality and price of services, but also by non-market (political) factors, including nonproliferation issues. $^{13}$

\section{Technological and economic aspects of competition}

Russian State Corporation Rosatom is currently the generally recognized leader in the market of nuclear materials and technologies suppliers. ${ }^{14}$ Rosatom holds the largest share (36\%) in the world uranium enrichment market, and a $17 \%$ share in the fabrication of nuclear fuel. The company received orders to construct 36 power units in Europe, Asia, the Middle East and North Africa. The construction of nuclear power plants in Bangladesh, Belarus, Hungary, Egypt, China, Turkey, and Finland utilize the Russian-designed VVER-1200 power units projects, which have high economic characteristics and meet modern safety requirements with active and passive protection systems. Apart from staff training and operation and maintenance support for the nuclear power plants it constructs, Rosatom also offers Russian nuclear fuel supplies for the entire plant life cycle, as well as reprocessing of spent nuclear fuel.

\footnotetext{
12 Small modular reactors: global outlook, AtomicExpert.com, 2 Mar. $2019<$ http:// atomicexpert.com/small_modular_reactors>.

13 'Nuclear Market: Old leaders retreat but don't give up', Energy Bulletin, 2019, no. 3 (70), p. 14-19<http://ac.gov.ru/files/publication/a/21476.pdf>.

14 'Russia leads the world at nuclear-reactor exports', The Economist, 7 Aug. 2018 $<$ https://www.economist.com/graphic-detail/2018/08/07/russia-leads-the-worldat-nuclear-reactor-exports>; 'Russia unrivaled in nuclear power plant exports', The Japan Times, 7 Aug. 2018 < https://www.japantimes.co.jp/opinion/2017/07/27/ commentary/world-commentary/russia-unrivaled-nuclear-power-plant-exports/\#. Xg2sa026wYI>.
} 
Rosatom's western competitors also offer 3+ generation reactors - AP-1000 (Westinghouse) and EPR (Framatome). However, both Western companies are experiencing serious problems. The lack of orders in the domestic market negatively affects their competencies, which, in turn, affects the external consumers.

The French Areva (Framatome), which won the tender to construct the Finnish nuclear power plant Olkiluoto-3 in 2003, is now in trouble. The construction of the EPR project power unit that begun in 2005 have not yet been completed, but its costs have grown significantly. Due to design flaws, the unit construction and its commissioning was delayed by more than 10 years. Areva paid Finland $450 \mathrm{mln}$ euro as compensation for excess construction costs and a delay in putting the unit into operation. ${ }^{15}$

The construction of two EPR units in China, which began in 2009, also suffered from cost overruns and dragged on for almost 10 years. Instead of the planned commissioning of the first unit in 2014 and the second in 2015, they began operating in 2018 and 2019. Failures with the construction of these units led to the fact that since 2007, Areva (renamed Orano) had been unable to win a single tender for the construction of new power units abroad and was forced to start a reorganization in $2015 .^{16}$

In 2007, the American Westinghouse signed a contract with a number of Chinese companies for the construction of four AP-1000 reactor units, but not a single unit has yet been built. The construction of the first reactor was started in 2009, and at the end of the same year, an intergovernmental agreement was signed between China and the United States on the transfer of AP-1000 technology to Chinese customers with the right to build an AP- 1000 in China. ${ }^{17}$ Clarifications and changes made to the contract during the construction process caused a significant number of alterations and created difficulties for

15 'Nuclear Power in Finland', WNA, Apr. $2020<$ https://www.world-nuclear.org/ information-library/country-profiles/countries-a-f/finland.aspx $>$.

16 'Russia unrivaled in nuclear power plant exports...' (note 14).

17 'Nuclear Power in China', WNA, Apr. $2020<$ https://www.world-nuclear.org/ information-library/country-profiles/countries-a-f/china-nuclear-power.aspx $>$. 
equipment manufacturers, while the construction budget grew 2.5-3 times. Westinghouse suffered major losses due to the delayed launch and initiated a managed bankruptcy procedure. ${ }^{18}$

The failures of Areva and Westinghouse made China a real competitor of Rosatom in the power unit market. Indeed, the country acquired the technologies and competencies to construct $3+$ generation units, putting several reactor units per year into operation on its own territory.

In 2013, the Chinese company China National Nuclear Corporation (CNNC) entered into an agreement to build two ACP-1000 units in Pakistan. The construction of the first unit began in 2015 and the second - in 2016. China entered into an intergovernmental agreement with Argentina on the construction of one Candu-type reactor and one ACP-1000-type reactor. In the second half of the 2010s, China also concluded agreements to participate in reactor construction projects in Romania, Turkey, Iran, South Africa, Kenya, Sudan, Egypt, Armenia, Uzbekistan, and Kazakhstan. ${ }^{19}$

\section{Political aspects of competition}

Nuclear export control on the global scale is being governed by the Nuclear Suppliers Group (NSG). In 1976, the NSG developed uniform guidelines for nuclear export, which are binding on all member states of the Group. The guidelines stipulate that the transfer of relevant materials, equipment and technologies from a supplier to a buyer is permitted "only upon formal governmental assurances from recipients explicitly excluding uses which would result in any nuclear explosive device." In 1992, the NSG was able to agree on and adopt the requirement that safeguards extend to all nuclear activities of the exporting countries of nuclear technologies and materials - the socalled principle of comprehensive safeguards.

\footnotetext{
18 'Nuclear Power in the USA', WNA, May $2020<$ https://www.world-nuclear.org/ information-library/country-profiles/countries-t-z/usa-nuclear-power.aspx $>$.

19 'Nuclear Power in China...' (note 17).
} 
However, in the late 1990 s and early 2000 s, a series of serious disagreements arose within the framework of the NSG when it had to consider the issue of nuclear exports and the admission of India and Pakistan to the group. At that time, both of these states had already mastered many steps of the nuclear fuel cycle and acquired nuclear weapons, but their nuclear activities had not been placed under comprehensive IAEA safeguards.

In 1998, Rosatom signed a contract for construction of two VVER-1000 reactors at Kudankulam NPP. Technically, it appeared that Russia signed this contract with India in violation of its international obligations, since India did not have comprehensive safeguards agreement in force with the IAEA. Russia justified its decision by citing an agreement on the construction of the first stage of the Kudankulam NPP signed between India and the Soviet Union in 1988, i. e. even before the NSG adopted its system of comprehensive safeguards. Regardless, Russia and India signed a memorandum obligating India to conclude a safeguards agreement with the IAEA. This agreement was signed in early 2009 and entered into force at the end of 2009. Two power units built by Rosatom at Kudankulam were put into operation in 2014 and 2017, respectively. At present, Rosatom is constructing the third and fourth power units at this nuclear power plant, and a contract has been signed for the construction of the fifth and sixth. In October 2018, during President Putin's visit to India, an agreement was reached on the construction of six more reactors at the new site. The reactors are to be constructed by Russia with some help from India.

Cooperation between China and Pakistan in the nuclear field began in 1990 after CNNC agreed to supply and construct the CNP300 reactor at Pakinstan's Chashma NPP. In 2000, a contract was signed for the construction of the second power unit. Just like India, Pakistan did not have a safeguards agreement with the IAEA. But it would be incorrect to accuse China of violating the embargo on supplying reactors to Pakistan, since Beijing was not a member of the NSG until 2004. The NSG, however, did have issues with China after it signed contracts for supplying the third and fourth power units to the Chashma NPPs. China explained that those units were being built in accordance 
with previously concluded agreements. As part of the agreement on the construction of the third and fourth units, Pakistan committed to put these reactors under the IAEA safeguards. ${ }^{20}$

The United States has always perceived its activity in the nuclear technology market not only as a tool to maintain the nuclear nonproliferation regime but also as a political (geopolitical) tool that would allow the United States as a nuclear supplier to deepen its political and economic influence on importing countries by strengthening its focus on the supply of materials and technology. U.S. nuclear cooperation with various countries is always preceded by the conclusion of a 123 Agreement, which imposes restrictions on the use of nuclear materials and technologies and also limits the capabilities of the buyer country in the international nuclear technology market.

Washington concluded a 123 Agreement with China in 1985, which was extended for another 30 years in 2015. This agreement gave China the right to acquire uranium enrichment and spent nuclear fuel management technologies abroad, as well as adapt and use U.S. projects for the construction of reactors in third countries. Through the 123 Agreement, U.S. companies, primarily Westinghouse, received a large number of contracts for the construction of reactors in China. Westinghouse in fact concluded an agreement on the construction of four AP-1000 reactors in China. However, deadline extensions and increased construction costs, as well as localization of production and intellectual property rights transfers to China, effectively made signing new contracts with Westinghouse unattractive for Beijing. These facts, coupled with Chinese companies' actions in the global nuclear market, displeased Washington, prompting it to revise the provisions of its 123 Agreement with China. ${ }^{21}$

\footnotetext{
20 'Nuclear Power in Pakistan', WNA, Feb. $2020<$ https://www.world-nuclear.org/ information-library/country-profiles/countries-o-s/pakistan.aspx $>$.

${ }^{21}$ Ford, C., Competitive Strategy vis-a-vis China: The Case Study of Civil-Nuclear Cooperation, Remarks to the Project 2049 Institute, US Department of State, 24 Jun. $2019<$ https://www.state.gov/competitive-strategy-vis-a-vis-china-the-casestudy-of-civil-nuclear-cooperation/>.
} 
Another example of the United States' use of nuclear cooperation for political purposes was its 123 Agreement with India. After intensive negotiations that began in 2005, the 123 Agreement with India was finally concluded in October 2008, thereby opening Indian nuclear market for U.S. companies. The United States has succeeded in making India divide its nuclear program into military and peaceful components and commit to putting the latter portion under IAEA safeguards. However, India was able to defend its right to reprocess SNF in reactors provided by foreign companies and use separated plutonium for energy production. India signed a safeguards agreement with the IAEA and the Additional Protocol in early 2009, and the agreement entered into force in October 2009. According to the Agreement, by the end of 2014, 14 Indian reactors had been placed under safeguards. ${ }^{22}$

As was the case with China, Washington's decision to sign a nuclear agreement with India was driven by prospects for nuclear trade with New Delhi. India's rather ambitious program for the development of its national nuclear energy program and its willingness to pay for the construction of dozens of nuclear reactors has led companies from the United States and several other countries - primarily Westinghouse and French Areva - to sign contracts with it. At the same time, preliminary agreements on the construction of six nuclear power plants in India by Westinghouse were reached only in 2016, after India had concluded an intergovernmental agreement on nuclear cooperation with Japan - almost seven years after the start of the negotiations. ${ }^{23}$ The final agreement on the construction of six American reactors in India was reached only in 2019.

22 'Nuclear Power in India', WNA, Mar. $2020<$ https://www.world-nuclear.org/ information-library/country-profiles/countries-g-n/india.aspx $>$.

23 Prior to this, Japan entered into agreements with Indian companies, as well as with large blocks of shares owned by the Japanese companies Toshiba and Hitachi, respectively. 
By developing its nuclear energy and mastering modern technologies with the help of foreign suppliers, India seeks to continue taking part in the export of nuclear technologies and materials. ${ }^{24}$ To this end, in 2016, India submitted an application to join the NSG, which would allow it to remove the existing market restrictions. Many countries, including Russia and the US, supported India on this issue. However, China and several other countries are opposed to India joining the NSG. The position of China in this case is determined not so much by the fact that India is not a party to the NPT (and, therefore, it's admission to the NSG could technically undermine the nonproliferation regime), but by the fact that, in China's view, India's accession to the NSG would be perceived negatively in Pakistan. According to China, Pakistan would want to keep up with India in the nuclear field, and this will upset the strategic balance in South Asia, which would threaten China's national interests. ${ }^{25}$

As for the United States, it is preoccupied with losing its role as a key provider of nuclear technology, as was described above. This concern stems mainly from the increased activity of Russia and China in the nuclear technology market. Washington has always perceived its position in this market as a geopolitical tool that allowed it to establish and strengthen its long-term political relations with importing countries. ${ }^{26}$ Experts also name weakening of U.S. position in the NSG and its diminished ability to set non-proliferation standards among other reasons for Washington's concern. ${ }^{27}$

\footnotetext{
24 'India can become a world manufacturer of equipment for small reactors under construction SMR-160', Atomic-energy.ru, 28 Nov. $2018<$ http://www.atomicenergy.ru/news/2018/11/28/90797>.

25 Skosyrev V. 'China will cut off India's access to nuclear technology', Nezavisimaya Gazeta, 14 Jun. 2016 <http:/www.ng.ru/world/2016-06-14/8_china. html> [In Russian].

${ }^{26}$ DiChristopher, T., 'The US is losing the nuclear energy export race...'

27 Hibbs, M., 'A More Geopoliticized Nuclear Suppliers Group', Carnegie Endowment for International Peace, 14 Dec. $2017<$ https://carnegieendowment. org/2017/12/14/more-geopoliticized-nuclear-suppliers-group-pub-75027>.
} 
The United States is particularly irritated by the fact that its 123 Agreement with China does not help advance its national security interests, especially in terms of non-proliferation. ${ }^{28}$ Explaining the growth and success of China's nuclear program by the systematic acquisition of foreign nuclear technologies by legal and illegal means and not providing any evidence that China's actions in the nuclear sphere undermine the non-proliferation regime, the USA intends to slow down the development of China's nuclear program. ${ }^{29}$ Basically, the 123 Agreement allows the United States to do so by imposing restrictions on certain provisions of the agreement and therefore hampering China's plans to export its nuclear technology.

Losing to its competitors in the nuclear market in terms of price and quality of services, the United States is developing new approaches to competition there. In early 2019, the State Department announced that the US government would seek to negotiate and conclude "memoranda of understanding in the field of nuclear cooperation" with foreign countries that do not yet have 123 Agreements with the United States. $^{30}$ In April 2020, the US Department of Energy published a report entitled "Restoring America's Competitive Nuclear Energy Advantage: A strategy to assure U.S. National Security," setting out plans to drive Russia and China from the nuclear technology market and restore U.S. nuclear leadership. ${ }^{31}$ Notably, the United States intends not only to increase subsidies to relevant U.S. industries but also to use non-economic methods.

\footnotetext{
28 Ibid.

29 Martsinkevich B. 'The US can stop China's nuclear development', IA Regnum, 16 Oct. $2018<$ https://regnum.ru/news/polit/2501687.html $>$ [In Russian].

30 Ford, C., Competitive Strategy vis-a-vis China...; State Department Official Previews New International Nuclear Agreements, 28 Feb. $2019<$ https://www. lexology.com/library/detail.aspx?g=9ffd984e-ebb1-4039-b574-9d4cdfead45c. $\operatorname{doc} x>$.

31 'Restoring America's Competitive Nuclear Energy Advantage', US Department of Energy, $2020<$ https://www.energy.gov/sites/prod/files/2020/04/f74/ Restoring\%20America\%27s\%20Competitive\%20Nuclear\%20Advantage-Blue $\% 20$ version $\% 5 \mathrm{~B} 1 \% 5 \mathrm{D}$.pdf $>$.
} 


\section{Risks to the non-proliferation regime}

Strict compliance with established international rules by participants of the global nuclear markets - both exporters and importers greatly facilitates the removal of proliferation risks in the context of the development and widespread use of nuclear energy.

The most important instrument of the non-proliferation regime is the Treaty on the Non-Proliferation of Nuclear Weapons and the IAEA safeguards regime (INFCIRC-153) developed under its framework. The safeguards regime assures control over diversion of significant quantities of fissile materials to non-peaceful purposes. Facilities under Agency safeguards include, but are not limited to, enrichment plants and spent nuclear fuel reprocessing plants. With the adoption of the Additional Protocol to the IAEA Safeguards Agreement in 1997, the system's efficiency has improved significantly. The adoption of the Additional Protocol has significantly expanded the IAEA's access to nuclear facilities and their design documentation, as well as introduced a new toolset for environmental monitoring that accurately detects residual quantities of fissile materials.

The NSG, which currently includes 48 nuclear supplier states, plays a decisive role in the global fight against illegal exports of nuclear materials, equipment, and technologies. In accordance with the 1992 NSG Guidelines, concluding a comprehensive safeguards agreement between the receiving state and the IAEA is a precondition for nuclear supply. In 2011, the NSG approved new, stricter guidelines for the export of technologies and equipment related to uranium isotope separation and spent nuclear fuel reprocessing.

In considering the risks to the non-proliferation regime on the part of exporting countries, some experts do not exclude the possibility that the competition in the global nuclear market might cause the underdogs to relax the requirements for importing states. ${ }^{32}$ Thus, it is advisable to evaluate the risks to the non-proliferation

${ }^{32}$ Nguyen, V.P. and Yim M.-S., 'Nonproliferation and Security Implications of the Evolving Civil Nuclear Export Market', Sustainability, 2019, Vol. 11, no. 7

$<$ https://www.mdpi.com/2071-1050/11/7/1830>. 
regime on the part of nuclear exporters in terms of their commitment to the basic rules of export control. As the analysis above shows, to date, all major nuclear exporters - Canada, China, the ROK, Russia, France, the US, and Japan - with some exceptions, have demonstrated their strong commitment to the guidelines on nuclear non-proliferation and export controls.

Examples of some deviations from these rules are agreements between Russia and India on the construction of reactors in India, the 2005 US-Indian agreement on nuclear cooperation, and SinoPakistani agreement on the construction of nuclear reactors. By signing an agreement on cooperation in the field of nuclear energy with India, first Russia, and then the United States, in fact recognized India's right to possess nuclear weapons without formal accession to the NPT. China effectively did the same for Pakistan. At the same time, with the signing of agreements on cooperation in peaceful nuclear energy, a significant part of India's and Pakistan's nuclear activities is now placed under the control of the IAEA.

For newcomers importing their nuclear technology, the mitigation of nuclear proliferation risks is mainly achieved through "institutional barriers," that is, through their adoption and fulfillment of a number of obligations without which they cannot count on exporters to help them develop nuclear energy. In accordance with the NSG rules approved in 2011, importing countries can count on assistance in the development of nuclear energy from the supplying countries provided that:

- they are members of the NPT and comply with their obligations under an agreement with the IAEA on comprehensive safeguards,

- they have a national export control system in place that meets the requirements of UNSCR 1540,

- they sign the Additional Protocol that has entered into force.

In addition, newcomers are also required to accede to the Vienna Convention on Civil Liability for Nuclear Damage, as well as to develop, adopt legislation and create the institutional infrastructure that is necessary for the safe use of peaceful nuclear energy and guarantees compliance with non-proliferation obligations. 
Of course, newcomer countries developing nuclear energy do not have experience in fulfilling their obligations to control export and non-proliferation. Therefore, the work of the IAEA Nuclear Security Fund is essential to help member states, especially newcomers, improve nuclear security by providing adequate physical protection for nuclear and radioactive materials. This assistance also focuses on organizing the work of the national regulatory authority to effectively prohibit illicit trafficking in nuclear and radioactive materials and ensure greater preparedness to combat the threat of nuclear terrorism.

Obviously, proliferation risks can be minimized when exporting countries successfully use mechanisms that could encourage newcomers not to acquire their own NFC technologies. One of the mechanisms could be the practice of concluding "package" contracts, within the framework of which the supply of power reactors would be inextricably linked with the supply of fresh fuel and the collection of spent nuclear fuel for the entire life period of its operation. For newcomer countries, the attractiveness of such a practice is not only that they are guaranteed the supply of nuclear fuel, but also the elimination of the problems of spent nuclear fuel management, which removes serious barriers to national nuclear energy development programs.

Another attractive mechanism for the newcomer countries allowing them to use nuclear energy could be creating their nuclear power plants on the "build, own, operate" principle. In this case, the supplier country not only builds a nuclear power plant, but also owns it and carries out all activities for its operation, as well as bears responsibility for safety. A similar mechanism is expected to be implemented during Rosatom's construction of the Akkuyu NPP in Turkey.

Naturally, the possibility of implementing such mechanisms weakens the competitive advantages of exporting countries that are not able to offer services across the entire NFC line. It also causes their concern both with regard to the possible weakening of global 
nuclear safety standards and losing their strategic impact. However, the specifics of the NSG guidelines and consensus-based decisionmaking can deter member state from using competitive advantages to lower the requirements for importing countries when concluding contracts for the supply of nuclear materials and equipment. 


\title{
4. NATO-RUSSIA RELATIONS AND ARMS CONTROL IN EUROPE
}

\author{
Sergey OZNOBISHCHEV
}

The critical state of the European security system today is a direct result of political disagreements between Russia and the West on the fundamental principles of international relations, international law, and ensuring mutual security. The keen political crisis in Ukraine of 2014 has become a ground for severe deterioration of Russia's relations with many key actors of world politics. As a result, mechanisms of ensuring security based on arms control, confidence-building measures, transparency, and cooperation have been subjected to further destruction.

In the summer of 2019 the US withdrew from the Treaty on the Elimination of Intermediate-Range and Shorter-Range Missiles (INF Treaty), creating a danger of a return to the critical situation of the early 1980s, when the US intermediate-range missiles (IRMs) had been deployed on the European continent. Conventional arms control in Europe (CACE) has reached even a deeper impasse. The prospects for the progress on "general direction", i.e. in the sphere of strategic nuclear arms reduction, are not clear, too.

All that remnants of the former system of European security, that had been frequently called "comprehensive", are the isolated and loosely connected fragments of arms control mechanism, in which Russia and NATO continue to play a crucial role. 


\section{NATO-Russia: no breakthrough in relations}

In recent years, the authors of this Yearbook have noted the signs of a slight restoring of elements of interaction between Russia and NATO. ${ }^{1}$ The main thing is that even after the Ukrainian crisis of 2014 the parties still manage to avoid military conflict scenario, despite the advancement of NATO military infrastructure and contingents towards Russian borders, NATO and Russian military build-up along the confrontation line, the increasing number of dangerous incidents at sea and in the air, and the larger-scale military exercises. This became possible, because at a certain point the parties showed restraint, while within NATO the member countries who call for more decisive action towards Russia are being contained.

Since 2014 Poland has demanded from the United States to deploy on its territory on a permanent basis heavy weapons, including tanks, and a U.S. military base. ${ }^{2}$ The Baltic states also requested a "permanent presence" of the NATO's military contingent on their territories. ${ }^{3}$ In 2018 the foreign ministers of the Baltic states once again asked the USA "to strengthen NATO battalions stationed in their territories with more air and navy forces". ${ }^{4}$ There were some other callings to the leadership of NATO from the alliance members bordering with Russia to increase the alliance' military presence in the region.

\footnotetext{
1 For more details, see: Oznobishchev, S., Bogdanov, K., 'NATO-Russia relations: any signs of stabilization?', SIPRI Yearbook 2018, pp. 652-664 [In Russian].

2 Traynor, I., 'US and Poland in talks over weapons deployment in Eastern Europe', The Guardian, 14 Jun. 2015 <https:/www.theguardian.com/world/2015/jun/14/ us-poland-weapons-deployment-eastern-europe-russia>.

3 Emmott, R., Siebold, S., 'NATO agrees to reinforce eastern Poland, Baltic states against Russia', Reuters, 8 Jul. $2016<$ https:/www.reuters.com/article/ us-nato-summit-idUSKCN0ZN2NL>.

4 'The Baltic states asked the USA to strengthen the NATO battalions', RIA Novosti, 17 May $2018<$ https://ria.ru/20180517/1520755867.html> [In Russian].
} 
Requests of such type, for the most part, were not granted. In conditions of a sharp deterioration of the NATO-Russia relations the Alliance's leadership developed a policy towards Russia which was formulated as "dual-track approach" - "meaningful dialogue on the basis of a strong deterrence and defense posture". 5

After deployment in 2016 of four NATO battalion-sized battlegroups in the Baltic countries and Poland, the total number of which must not exceed 4,500 troops, according to the decision of the 2018 NATO Brussels Summit, there has been no further build-up in military presence. These battlegroups are being rotated on a regular basis, and this should be regarded, together with limitation of their total number, as an indication of the NATO's commitment to provisions of 1997 NATO-Russia Founding Act, which involves "rotational" and time-limited nature of the NATO military presence on the territories of new member countries. Moreover, according to the official foreign sources, ${ }^{6}$ the individual (national) ceilings on conventional armaments and equipment, established under the Treaty on Conventional Armed Forces in Europe (CFE), are not being filled neither by NATO countries, ${ }^{7}$ nor by Russia. ${ }^{8}$ This may indicate that despite the strained relations, neither party in reality is preparing for military actions.

\footnotetext{
5 Relations with Russia, NATO official website, 5 Aug. $2019<$ https://www.nato.int/ cps/ru/natohq/topics_50090.htm?selectedLocale=en>.

${ }^{6}$ For more details, see: 'Vehicle and Aircraft Holdings Within the Scope of the Conventional Armed Forces in Europe Treaty 2017', Ministry of Defence $<$ https://www.gov.uk/government/uploads/system/uploads/attachment_data/file/>. 7 Under non-official agreement within NATO, the ceilings on the treaty-limited equipment (TLE) assigned to NATO as 'a group of state parties' were distributed between the treaty's state parties.

8 According to the 1992 Tashkent Agreement on the Principles and Procedures for the Implementation of the Treaty on Conventional Armed Forces in Europe, which was signed by Armenia, Azerbaijan, Belarus, Georgia, Kazakhstan, Moldova, Russia and Ukraine "the maximum levels for holdings of conventional armaments and equipment" - i.e. so-called 'USSR quota' on the TLE - were redistributed between these new independent states created in the territory of the former Soviet Union.
} 
As it was to be expected, NATO supported Washington's decision to withdrawal from the Intermediate-Range Nuclear Forces Treaty in 2019. However, it was stated at the high official level, which includes the NATO leadership, that there is no intention "to deploy new land-based nuclear missiles in Europe".

The NATO-Russia Council (NRC), whose activity had been "frozen" by Brussels after the outbreak of the Ukrainian crisis, is gradually resuming its work. The frozen dialogue was contrary to the very idea of the NRC, which was intended to serve as a mechanism of a crisis regulation and not depend on fluctuations in relations between the parties. Nevertheless, the Council has held about ten meetings since 2016, during which such topical problems as the situation in Ukraine, security issues in Afghanistan, so-called "hybrid challenges", risk reduction of military incidents "in conditions of increased military activity of both sides", air safety over the Baltic sea, military transparency issues, including the transparency of military exercises, and the INF crisis were discussed..$^{10}$

One of the practical outcomes of the Council's meetings was reducing the danger of combat aviation flights over the Baltics that had been performed earlier mostly with turned-off transponders. Discussions within the NRC facilitated the work of the Baltic Sea Project Team, which actively cooperated with the International Civil Aviation Organization (ICAO), including on the transponders issue. As a result, the Russian Deputy Foreign Minister Alexander Grushko was able to note in 2017 that recently "nobody can hear anything [about the transponders], because certain arrangements were reached within these group that have partly solved the problem". ${ }^{11}$

\footnotetext{
9 Press conference by NATO Secretary General Jens Stoltenberg following the meetings of NATO Defence Ministers, 13 Feb. $2019<$ https:/www.nato.int/cps/ en/natohq/opinions_163394.htm>.

10 'The NATO-Russia Council', RIA Novosti, 5 Jul. $2019<$ https://ria.ru/20190705/ 1556158436.html> [In Russian].

11 'The Permanent Representative of the Russian Federation to NATO called the issue of turned-off transponders partly solved', Interfax, 7 Feb. $2017<$ https:// www.interfax.ru/russia/548908> [In Russian].
} 
According to the president of Finland Sauli Niinistö, "it is the flight security that became the issue on which Russia and Finland found common ground". Thanks to decisions made in 2017, the number of (military) flights over the Baltic Sea with devices used for identification being turned off decreased to $25 \%$, compared to $42 \%$ in 2016 and $56 \%$ in $2015 .^{12}$

The high-level military representatives meetings that were started by the sides have led to a certain breakthrough in avoiding military incidents. In 2016, a telephone "hotline" between the Russian and NATO military officials has been restored, and since 2017 personal meetings of the Chief of the General Staff, the First Deputy Defense Minister of the Russian Federation Valery Gerasimov with senior NATO military have been taken place in Baku. These contacts have then become permanent.

At these meetings military officials inform each other on the character and the aims of military exercises, exchange information on issues of concern, discuss ways "of promoting predictability" and "reducing misperceptions", as well as problems of "military activities of Russia and NATO in the European region". Questions of finding practical ways of strengthening "confidence-building and incidentprevention measures", primarily - along the borders between Russia and the NATO countries, have also been raised in these discussions. ${ }^{13}$

The latest high-level discussion of that kind was the meeting of Valery Gerasimov with General Tod D. Wolters, NATO's Supreme Allied Commander Europe, on 6-7 February, 2020. It addressed

12 'Military aircrafts became less likely to fly over the Baltic sea with transponders off', Interfax, 27 Dec. $2017<$ https://www.interfax.ru/world/593621> [In Russian].

${ }_{13}$ See: 'Chief of General Staff of the Russian Federation met with NATO's Supreme Allied Commander Europe', Ekho Kavkaza, 20 Apr. $2018<$ https://www. ekhokavkaza.com/a/29180982.html> [In Russian]; Ivanov, V., 'Russia and NATO will continue a dialogue', Nezavisimoe voennoe obozrenie, 20 Feb. $2020<\mathrm{http} / /$ nvo.ng.ru/nvoevents/2020-02-02/100_rfnato020220.html> [In Russian]. 
the problems of stabilizing of military relations of the two sides and more broader issues of strategic stability and the situation in crisis regions worldwide. ${ }^{14}$

Thus, a mechanism for crisis prevention in military sphere between Russia and NATO was created and it has begun to work. It could not take place without the consent of the state leaders of Russia and NATO, which means, that it is a channel for an indirect dialogue between the parties, indicating their willingness to build more stable and predictable relationship.

NATO official documents maintain and reaffirm the commitment "to the preservation and strengthening of effective arms control, disarmament, and non-proliferation mechanism". ${ }^{15}$ However, in practice, the NATO bureaucratic apparatus still remains resolute to act within the course formulated by the US State Department towards Moscow back in 2014: "no business as usual". Nevertheless, the analysis of a number of important elements of the NATO-Russia relationship shows that the negative dynamics of its development has been suspended.

\section{"Nuclear problems" of European security}

The Treaty on the Elimination of Intermediate-Range and ShorterRange Missiles has become actually one of the recent victims of escalating of relations between Russia and the West. Whatever one might say, this treaty was a big victory of Soviet foreign policy and diplomacy. As a result of its implementation, the USA had destroyed

\footnotetext{
14 'The Chief of the General Staff of the RAF Gerasimov and the NATO's SACEUR met in Baku', REGNUM, 6 Feb. $2020<$ https://regnum.ru/news/ polit/2851292.html> [In Russian].

15 'London declaration issued by the Heads of State and Government participating in the meeting of the North Atlantic Council in London', NATO official website, 4 Dec. $2019<$ https://www.nato.int/cps/en/natohq/official_texts_171584. htm?selectedLocale $=\mathrm{en}>$.
} 
846 missiles that represented a strategic military threat to Moscow, since the USSR could not "counterbalance" it by creating the same threat for the US territory.

The abovementioned worsened relations and the lack of dialogue have resulted in arising disputes and mutual claims concerning the Treaty, which had not been solved. Finally, in 2019 Washington withdrew unilaterally from the INF Treaty. In this context, Russia made a commitment not to deploy intermediate-range and shorterrange missiles "unless corresponding missile systems produced in the USA are deployed in a given region". ${ }^{16}$ In September 2019 the President of Russia Vladimir Putin addressed the heads of leading countries, including the United States and other NATO countries, calling to "support the initiative in order to avoid a new missile arms race, primarily on the European continent". ${ }^{17}$

It was declared in response that "NATO sees no point in the moratorium on the deployment of intermediate- and shorter-range missile in Europe proposed by Moscow", as in the view of the Alliance, Russia has already deployed such missiles on its territory. ${ }^{18}$ However, despite the failure of attempts to preserve the treaty, there has been no repeated deployment of IRMs on the continent, as was the case in the early 1980s.

With the critical state of arms control, the persistent principal disagreements on the ballistic missile defense (BMD) in Europe became less visible. It must be recalled, that according to the White House position, the European BMD was originally intended to avoid in the near-term "the greatest missile threats from Iran... to U.S. Allies

\footnotetext{
16 'Joint news conference with President of Finland Sauli Niinistö', President of Russia, 21 Aug. 2019 <http://en.kremlin.ru/events/president/news/61349>.

17 'Antonov: Russia is ready to make an agreement with the USA on an extension of the New START even today', TASS, 1 Apr. $2020<$ https://tass.ru/politika/8129675> [In Russian].

18 'NATO sees no point in the moratorium on deployment intermediate-range missile in Europe', TASS, 20 Oct. $2019<$ https://tass.ru/mezhdunarodnayapanorama/7023412> [In Russian].
} 
and partners, as well as to U.S. deployed personnel". ${ }^{19}$ NATO's point of view on this matter, which had been expressed many times by its Secretary-General, fully reproduced American official language. ${ }^{20}$ The key point here was that the NATO's BMD is purely defensive in nature and is not directed against Russia. ${ }^{21}$

Given the extremely low level of trust between Russia and NATO, such assurances are not taken seriously in Russia on the official level, as well as by the wide range of politicians, military and civilian experts. President Vladimir Putin expressed a widespread view that "the whole system is created to reduce the nuclear potential of all states except for the USA to zero". 22

Following cut-off of NATO-Russia substantial dialogue on European BMD, which had been started in the 2000s, the mutual understanding in the area of ballistic missile defense has disappeared. Instead of becoming the key link of interaction, "crucial for transformation of mutual nuclear deterrence" 23 of both parties, the European BMD problem turned into one of the significant factors of perception by Moscow of the military threat from the USA and NATO.

In recent years, another thesis became widespread in Russia as well. It is that European BMD has a "hidden" function, differing from that had been declared by the creators of this system - the possibility of its perspective use as a platform for launching direct strikes on

19 'U.S. Missile Defense Policy. A Phased, Adaptive Approach for Missile Defense in Europe', The White House official website, 17 Sept. 2009

$<$ https://obamawhitehouse.archives.gov/the-press-office/fact-sheet-us-m issile-defense-policy-a-phased-adaptive-approach-missile-defense-eur>. 20 See, for example: 'Hillary Clinton oversees US missile base deal in Poland', BBC, 3 Jul. $2010<$ https://www.bbc.com/news/10497684>.

21 'Key missile defence site declared operational', NATO official website, 12 May 2016. <https://www.nato.int/cps/en/natohq/news_130721.

htm? selectedLocale $=$ en $>$.

22 'Putin: the US BMD poses a threat to the nuclear potential of the Russian Federation, that changes the philosophy of world security', TASS, 22 Oct. 2015 $<$ https://tass.ru/politika/2371581> [In Russian].

${ }^{23}$ Dvorkin, V., 'It is time to forget about the European BMD threat', Nezavisimoe voennoe obozrenie, 30 Sept. $2009<\mathrm{http}: / /$ nvo.ng.ru/concepts/2011-09-30/1_pro. html> [In Russian]. 
the Russian Federation. As Vladimir Putin noted, "these compact launch pads can accommodate assault missiles with a 2,400-kilometre range, and replacing the missiles is no problem, one only has to change the software, and nobody is going to notice anything". ${ }^{24}$

In practice, such an action would be technically more complicated, and, beyond that, the deployment of several dozens of cruise missiles in Europe, in addition to the thousands that the United States already have in its fleet and aviation, would be unable to change drastically the military balance. Furthermore, according to the estimates of specialists from the Central Research Institute of Aerospace Forces of Ministry of Defense of the Russian Federation, all available means of that type have limited potential, and thus, "the theoretical ability to disarm $\mathrm{SNF}^{25}$ only on the basis of high-precision weapons, without the aggressor's use of nuclear forces" is absolutely impossible. ${ }^{26}$

The acuity of contemporary challenges in arms control has overshadowed the problem of tactical nuclear weapons (TNW) in Europe. The TNW agreements of 1991 and 1992 envisaged radical (by an order of magnitude) reduction of tactical nuclear weapons. The form of these agreements was rare enough for their time, although this was a period when the air of cooperation and partnership was sizeable in the US-Russian relations. The unique character of the 19911992 agreements was that some of the proposed measures were implemented unilaterally and others - on a mutual basis. At the same time, no document has been signed to confirm the oral agreements.

As a result, very large cuts were achieved. By June 1992, the United States had removed a total of 1700 warheads of its TNW ground-to-ground component from abroad (700 Lance missile warheads and 1000 artillery shells). 450 warheads (150 Lance missile warheads and 300 artillery shells) that were stored in the USA were dismantled. The United States also withdrew 500 warheads of its seaborne tactical

24 'Joint press conference with Prime Minister of Greece Alexis Tsipras', President of Russia, 27 May 2016 <http://en.kremlin.ru/events/president/news/52024>.

${ }_{25} \mathrm{SNF}$ - strategic nuclear forces [Author's note].

26 Akhmerov, D., Akhmerov, E., Valeev, M., 'It will not work out quickly', Voennopromyshlennyi kur'er, 19 Oct. $2015<$ https://www.vpk-news.ru/articles/27617> [In Russian]. 
nuclear force (100 W80 warheads deployed on SLCMs, 400 B57 depth bombs and B61 gravity bombs). 350 B57 depth bombs were removed from service by the United States. Then all depth bombs were destroyed. ${ }^{27}$ According to the professional foreign sources, the result of implementation of the 1991-1992 agreements was that United States and Russia had cut their deployed TNW stockpiles by 5,000 and 13,000 warheads, respectively. ${ }^{28}$

Reliable foreign expert sources estimate the actual potential of Russian non-strategic nuclear forces to be at a level of approximately 1800 warheads. $^{29}$ According to the Russian official assessments, the USA has "up to 200 aerial bombs" in Europe and plans to modernize these munitions. One of Moscow's claims is that the USA still possesses nuclear weapons abroad, while Russia "withdrew all its nuclear munitions to the national territory". ${ }^{30}$

The US nuclear forces deployed in Europe are regarded as an element of "jointly implemented" collective strategy of nuclear deterrence. In this arrangement the United States "has forward deployed weapons" and the European allies "provide support, bases, infrastructure". ${ }^{31}$ Although the NATO official documents usually reaffirm Alliance's commitment "to the preservation and strengthening

27 Lockwood, D., Wolfsthal, J.B., 'Nuclear weapon developments and proliferation', SIPRI Yearbook 1993: Armaments, Disarmament and International Security, Stockholm International Peace Research Institute, Oxford University Press, 1993, pp. 224-225.

28 'U.S.-Russian Nuclear Arms Control Agreements at a Glance', Arms

Control Association, Apr. $2020<$ https://www.armscontrol.org/factsheets/

USRussiaNuclearAgreements Last Reviewed $>$.

29 'Nuclear Weapons in Russia. Russian Nuclear Sites and Weapons Programs', Nuclear Threat Initiative, Oct. $2018<$ https://www.nti.org/learn/countries/russia/ nuclear>.

30 'The Foreign Ministry called on the USA to withdraw its nuclear forces from the European territory', RT-TV channel, 18 Dec. $2017<$ https://russian.rt.com/world/ news/461894-mid-ssha-vyvod-vooruzhenie $>$ [In Russian].

31 'Round table with NATO Secretary General Jens Stoltenberg and representatives of the media at the Munich Security Conference', NATO official website, 15 Feb. $2020<$ https://www.nato.int/cps/ru/natohq/opinions_173795.

htm?selectedLocale $=\mathrm{ru}>$. 
of effective arms control, disarmament, and non-proliferation, taking into account the prevailing security environment", ${ }^{32}$ they are not followed by concrete proposals.

In the context of worsened Russia-West relations, new U.S. initiatives to strengthen "nuclear safeguards" for Europe were foreseeable. Thus, the US Nuclear Posture Review, adopted in 2018, announced plans to expand "if needed" forward deployments of nuclear bombers and dual-capable aircraft (DCA) that can deliver nuclear weapons, including new F-35 fighters. At the same time, the US side also declared the goal "to work with NATO to best ensure - and improve where needed - the readiness, survivability, and operational effectiveness of DCA based in Europe". ${ }^{33}$

The strengthening of the "nuclear component" in Europe was negatively perceived in Moscow. As the official representative of the Russian Foreign Ministry noted, "We consider the NATO practice of so-called 'joint nuclear missions' absolutely unacceptable". It includes elements of nuclear planning and development of skills to use U.S. nuclear weapons deployed in Europe, together with nuclearcapable aircraft, their crews, airfields and ground support services of the alliance's non-nuclear member states. ${ }^{34}$ All this, as the Russian Foreign Ministry stressed, "is a violation of the provisions of the Nuclear Non-Proliferation Treaty".

\footnotetext{
32 'London Declaration issued by the Heads of State and Government participating in the meeting of the North Atlantic Council in London', NATO official website, 4 Dec. $2019<$ https://www.nato.int/cps/en/natohq/official_texts_171584. 


\section{Conventional arms control in Europe: interrupted process}

One should regard returning to the conventional arms control agenda as a priority for Europe. The end of the Cold War made it possible to develop and conclude promptly the 1990 Treaty on Conventional Armed Forces in Europe. The treaty implementation had enabled States parties to reduce 59,000 heavy weapons, ${ }^{35}$ which was a clear breakthrough in strengthening security on the continent.

The CFE Treaty, actually, was aimed at implementing the principle of "strategic stability" to balance all European conventional armed forces at the regional scale. The negotiating Mandate on conventional forces declared the elimination "as a matter of priority, of the capability for launching surprise attack and for initiating large scale offensive action". ${ }^{36}$ By it the fundamental principle of strategic stability agreed in the course of negotiations on strategic offensive arms and anti-ballistic missile defense, which implies elimination of incentives for a first strike, was brought into effect.

New geopolitical realities - the dissolution of one of the military blocs (the Warsaw Treaty Organization) and the collapse of the USSR - have made it necessary to introduce fundamental changes into conventional arms control process in Europe. The Adapted Conventional Armed Forces in Europe Treaty (Adapted CFE), signed in 1999, presumed the transition from bloc-to-bloc limits of the CFE Treaty to national and territorial ceilings, which posed restrictions on treaty limited equipment of state parties. It should be noted that, unlike the process of elaboration of the CFE Treaty, preparations for the Adapted CFE ratification were in fact negotiated under the auspices of NATO.

\footnotetext{
35 'The Treaty on Conventional Armed Forces in Europe. Dossier', TASS, 12 Jul. $2017<$ https://tass.ru/info/1818829> [In Russian].

36 Mandate for negotiation on conventional armed forces in Europe, Concluding document of the Vienna meeting 1986 of representatives of the participating states of the conference on security and co-operation in Europe, held on the basis of the provisions of the Final act relating to the follow-up to the conference. OSCE, Vienna, $1989<$ https:/www.osce.org/files/f/documents/a/7/40881.pdf>.
} 
Due to the deterioration of political relations between Russia and the NATO the ratification of the treaty was constantly being delayed. The Russian side was less and less satisfied with the fact that the treaty did not take into account the changing military and political realities in Europe that were not in Moscow's favor, first of all, the growth of potential acquired by the alliance as a result of two waves of NATO enlargement. As it was noted in official documents of the Russian Foreign Ministry, the Western countries, for their part, began to link the Adapted CFE ratification "to Russia's compliance with conditions not related to arms control, in particular, the withdrawal of Russian troops from Georgia and Moldova". ${ }^{37}$

Russia's bilateral agreements with Georgia and Moldova were fixed in the final Istanbul document 1999. The Adapted CFE Treaty also became a part of it, which implied the equal legal significance of these documents. ${ }^{38}$ However, the West sacrificed the priority of achieving another important stage of arms control in Europe to "the letter of the law", i.e. the demand for scrupulous implementation of all provisions of agreements that were being gradually implemented, albeit not in full compliance with the rules.

The West's procrastination of the Adapted CFE ratification gave Moscow an excuse to suspend "partially" (since 2007) and then "completely" (since 2015) its compliance with the CFE Treaty. ${ }^{39}$ Despite choosing such an exotic legal form of action, Russia did not withdraw

\footnotetext{
37 The Treaty on Conventional Armed Forces in Europe (CFE Treaty) and conventional arms control in Europe, Summary, Official website of the Ministry of Foreign Affairs of the Russian Federation, 25 Jan. $2019<$ https://www.mid.ru/ru/ obycnye-vooruzenia/-/asset_publisher/MlJdOT56NKIk/content/id/1137833> [In Russian].

38 Istanbul document 1999. OSCE, Istanbul, $1999<$ https:/www.osce.org/files/f/ documents/6/5/39569.pdf $>$.

39 Statement by the Chief of the delegation of the Russian Federation to the negotiations in Vienna on issues of military security and arms control A. Yu. Mazur at the plenary meeting of the Joint Consultative Group for the Treaty on Conventional Armed Forces in Europe. Vienna, Ministry of Foreign Affairs of the Russian Federation, 10 Mar. 2015 <https://www.mid.ru/obycnye-vooruzenia/-/ asset_publisher/M1JdOT56NKIk/content/id/1089925> [In Russian].
} 
from the treaty, though strongly demonstrated in recent years a critical attitude towards it. In Moscow's official political lexicon emerged a formula that the CFE is "dead and there will be no return to it". ${ }^{40}$

For its part, NATO constantly emphasizes that all NATO Allies continue to comply with the Treaty on Conventional Armed Forces in Europe. Furthermore, according to the NATO Deputy SecretaryGeneral Rose Gottemoeller, "NATO is committed to strengthening and modernizing conventional arms control". ${ }^{41}$

In the future, the strengthening of European security will certainly require the revitalization and development of conventional arms control on the continent. And here, the political impulse from Moscow and Brussels will be vital.

The development of confidence-building measures in Europe is also an important task on the way to return to stability and security on the continent. In this regard, the quantitative parameters ('thresholds') of notification of certain military activities in the existing 2011 Vienna Document on confidence- and security-building measures (VD2011) are of crucial significance. These thresholds are stabilizing elements designed, along with the CFE Treaty, to fulfill the same tasks of elimination opportunities for a sudden attack and large-scale offensive actions.

According to VD2011, the participating states must notify about their military activity, "Whenever it involves at any time during the activity: at least 9,000 troops, including support troops, or at least 250 battle tanks, or at least $500 \mathrm{ACVs}^{42} \ldots$ or at least 250 self-propelled and towed artillery pieces, mortars and multiple rocket-launchers (100 $\mathrm{mm}$ caliber and above) if organized into a divisional structure or at

40 'The Treaty of Conventional Forces in Europe. Dossier', TASS, 12 Jul. 2017, $<$ https://tass.ru/info/1818829 > [In Russian].

${ }^{41}$ Remarks by NATO Deputy Secretary General Rose Gottemoeller at the Seventh EU Non-Proliferation and Disarmament Conference, NATO, 18 Dec. $2018<\mathrm{https} / / /$ www.nato.int/cps/en/natohq/opinions_161702.htm?selectedLocale=en>.

${ }^{42} \mathrm{ACV}$-armored combat vehicle [Author's note]. 
least two brigades/regiments". ${ }^{43}$ Thus, at the present stage the Vienna Document is intended to serve as a deterrent to holding in Europe major military exercises, exceeding the agreed limits (thresholds).

However, the West is concerned not only about the maneuvers, but also about the large-scale "inspections of operational readiness" which, according to Moscow, do not fall under the parameters of the Vienna Document 2011. Thus, on 17-21 July 2020 a large-scale operational readiness inspection of the troops and forces of the Southern and Western Military Districts, Airborne and Marine forces was held. The surprise operational readiness inspection involved approximately 150,000 military personnel, about 400 air vehicles, over 26,000 pieces of weapons, military and special equipment, over 100 ships and supply vessels. ${ }^{44}$

NATO states actively advocate for further developing confidence-building measures in Europe. The statement by Rose Gottemoeller mentioned above has a continuation and declares the NATO's commitment to strengthening and modernizing "confidence and security-building measures, such as the Vienna Document which is a cornerstone of Euro-Atlantic security". ${ }^{45}$ It is the combination of CACE modernization and confidence-building measures that can make effective security in Europe possible. It was no coincidence that the Vienna negotiations on conventional forces in Europe and confidence-building measures in 1989-1990 were conducted by national delegations of all participating countries with the same composition and at the same time.

Nevertheless, Russia announced that it was impossible to promote confidence-building measures at a stalemate in the negotiations on CACE. It was stated that "when the former Treaty on Conventional

\footnotetext{
43 Vienna Document 2011 on confidence- and security-building measures, OSCE, 30 Nov. $2011<$ https://www.osce.org/files/f/documents/6/5/39569.pdf>.

44 'Surprise inspections in the Russian Armed Forces', TASS, 22 Jun. $2020<$ https:// tass.ru/armiya-i-opk/9021125> [In Russian].

45 Remarks by NATO Deputy Secretary General Rose Gottemoeller at the Seventh EU Non-Proliferation and Disarmament Conference, NATO official website, 18 Dec. $2018<$ https://www.nato.int/cps/en/natohq/opinions_161702. htm?selectedLocale $=\mathrm{en}>$.
} 
Armed Forces in Europe (CFE) almost ceased to exist, and there is nothing new to replace it now or in foreseeable future, it is simply impossible to modernize seriously the Vienna Document 2011". 46

The Russian side reinforced this position by another argument. According to Alexander Glushko, Moscow sees the contradiction in the fact that, on the one hand, NATO member countries are intensifying "blatantly hostile" military activities near the Russian borders, and on the other hand, propose additional confidence-building measures in the OSCE framework. ${ }^{47}$ Thus, Russia has taken the initiative to align into one "package" several problems of ensuring European security through the negotiation process.

The crisis in all areas of arms control has not left aside the Treaty on Open Skies, which is another dimension of confidencebuilding measures that complement the verification regime for agreements. Against the backdrop of the collapse of many arms control treaties, the significance of the Open Skies Treaty (OST) has increased, especially in the context of growing tensions in Europe.

On several occasions representatives of Western countries used the mechanism of the treaty to conduct observation flights over the Russian territory bordering with Ukraine, trying to find "places of concentration of Russian forces". Those flights served as a stabilizing factor, contributing to contain a further escalation of the Ukrainian crisis.

The destructive policy of the Trump administration affected this arms control agreement as well. In 2019 the White House took a course to the withdrawal from the treaty, and in May 2020 the forthcoming withdrawal was officially announced. As a pretext Washington

\footnotetext{
46 'The Foreign Ministry: there are no conditions for modernization of the agreement on confidence-building measures today', TASS, 27 Nov. 2015 $<$ https://tass.ru/politika/2480726> [In Russian].

47 'Strengthening distrust measures in Europe: Russia rejected new arms control proposals of the West', Kommersant, 5 Dec. $2019<$ https:/www.kommersant.ru/ doc/4181142> [In Russian].
} 
used the thesis that Russia had "violated" the provisions of the OST, which "fueled distrust and threats to our national security", making "continued U.S. participation untenable". ${ }^{48}$

The European members of NATO do not share Washington's position on this issue entirely. Agreeing that Russia violates the provisions of the agreement by restricting flights over some of its territories, ${ }^{49}$ the NATO European members oppose the withdrawal from the OST and declare the goal of "engagement" with Moscow "to seek Russia's return to compliance at the earliest date possible". ${ }^{50}$

Similar to the situation with the INF Treaty, it became necessary in the context of the OST to remove the claims that both sides have. It is not unusual that over the duration of the treaty the member states have accumulated a number of critical comments to the partners regarding certain elements of its implementation. And the provisions of the agreement (Article X) stipulate the creation of an ad hoc body for dispute resolution, the Open Skies Consultative Commission, where the member states "consider questions relating to compliance with the provisions of this Treaty". ${ }^{51}$ If this Commission worked effectively, such Russian claims as, for instance, the "refusal to provide overnight stays on the United States mainland" 52 and many other purely technical issues could have been quickly resolved.

However, this does not happen due to the deficit of political will to resolve mutual claims, rather than the lack of organizational and technical opportunities, as it was the case with the INF Treaty,

\footnotetext{
48 'Press Statement by Michael R. Pompeo, Secretary of State on the Treaty on Open Skies', U.S. Department of State, 21 May $2020<$ https:/www.state.gov/ on-the-treaty-on-open-skies/>.

${ }^{49}$ For more details, see: 'Statement by the NATO Secretary General on the Open Skies Treaty', NATO, 22 May $2020<$ https://www.nato.int/cps/ru/natohq/ news_175945.htm?selectedLocale $=$ en $>$.

50 Ibid.

51 'Treaty on Open Skies', OSCE official website, 24 Mar. $1992<\mathrm{https}$ ://www.osce. org/files/f/documents/1/5/14127.pdf>.

52 'Zakharova stated that the Russian Federation has a number of its claims towards the USA under the Treaty on Open Skies', TASS, 21 May $2020<$ https://tass.ru/ politika/8534219> [In Russian].
} 
too. This destructive analogy might be continued, and the treaty will collapse if the OST member states do not make vigorous efforts to save it.

In general, there is a crisis situation in all spheres of arms reduction and limitation process in Europe, with differences only in its depth. Nonetheless, it can be said that the deterioration of Russia-NATO relations has so far been halted and frozen in a precarious balancing position. However, the high level of tension along the NATO-Russia military "line of contact" does not allow a delay in resolving problems that directly threaten European security. Obviously, the collapse of the treaty system is not in the long-term interests of the parties. Therefore, it is necessary to find ways to save what is still possible to save.

First of all, it is important to maintain the nascent restraint in the arms control sphere, i.e. not to deploy new IRBMs on the continent, to restore dialogue on the BMD in Europe, not to build up the TNW, to strictly adhere to the limitations agreed in the CFE Treaty, to search for solutions of problems regarding confidence-building measures, to make efforts to save the OST.

In general, one should tackle all these accumulated issues as a two-level task. For this purpose it is necessary to start immediately and unconditionally a dialogue to solve problems that pose direct threat to mutual security, whereas to postpone to "better times" the discussion of fundamental disagreements between Russia and the West/ NATO.

Prevention of possible dangerous incidents and de-escalation of conflict situations should be addressed as a priority. In particular, it is high time to adopt additional rules for cases of rapprochement of aircraft and ships on the basis of Soviet-American documents the 1972 Agreement on the Prevention of Incidents on and over the High Seas and the 1989 Agreement on the Prevention of Dangerous Military Activities. The issue of combat aviation flights over the Baltic Sea should be resolved as well. All countries concerned should make commitments to perform such flights only with turned-on transponders.

The parties of the European process should also consider creating a zone of reduced concentration of forces and lowered military activity along the borders with the prospect of expanding 
it. Recently, the Russian side has made several proposals to that end, including reducing the intensity of training activities near the border and relocating major operational and combat training events deeper into the border countries. It also expressed willingness to adjust in the future the places of trainings on a parity basis with NATO. In addition, Moscow unilaterally informed that the Russian Armed Forces do not plan to conduct major exercises near the borders of NATO member states this year. ${ }^{53}$

NATO should move away from its recently established practice of dismissing Russia's proposals out of hand. Even if it does not agree at the moment with Russian initiatives, Brussels might put forward counter-proposals, and then the parties might bring their positions closer to a compromise solution. It is this principle - the convergence of "application positions" - that forms the basic scheme of any negotiations.

The existing "platforms for dialogue" - the NATO-Russia Council and meetings of high-level military representatives of the parties - could be used more intensively to facilitate the achievement of these goals. They could consider in detail recommendations on resolving urgent "first-level" issues, as well as ways to return to a broader permanent engagement and resolution of existing military issues in European security. In order to effectively move forward in these areas, clear signals from the upper echelons of political power of the USA, Russia and of other European countries are needed.

53 For more details, see: 'Chief of the Main Operational Directorate of the General Staff of the Russian Armed Forces held a briefing on the level of NATO activity near the borders of Russia', Ministry of Defense of the Russian Federation, 1 Jun. $2020<$ http://eng.mil.ru/en/news_page/country/more.htm?id=12295316@, egNews $>$ [In Russian]. 


\section{CHALLENGES AND THREATS OF MILITARY USE OF ARTIFICIAL INTELLIGENCE}

\section{Pavel KARASEV}

Scientific and technological progress and the development of military thought go hand in hand. Recent decades have witnessed active development of new technologies in the military and security sectors, and a lot of research is being carried out in this area. Artificial intelligence (AI) and its specific applications are increasingly being considered one of the most important fields for research and innovation. The developed countries of the world have made it their goal to become leaders in the field of research and use of AI and plan to do so in the very near future. The products of this race are expected to be used in both civil and military spheres. At the same time, many scientists and public activists argue that the military use of AI is fraught with danger, and states should abandon some of it, in particular, the use of lethal autonomous weapon systems (LAWS).

To identify the challenges and threats of military use of artificial intelligence, we should analyze this issue on several levels. First of all, it is the technological level as such. Secondly, there is the level of application - the challenges and threats posed by the possible use of autonomous weapons systems. Thirdly, there is the policy levelthe probable threats to international security resulting from the military use of AI and the challenges of regulating this sphere.

\section{The technological level}

At the moment, there is no generally accepted universal definition of the term "artificial intelligence". Experts distinguish two large categories - "weak" and "strong" AI. Presently, the efforts to create "strong" AI are at the stage of theoretical studies and experiments. 
According to Academician Igor Kalyaev ${ }^{1}$ of the Russian Academy of Sciences, "the creation of a strong artificial intelligence, that is, a computer analogue of the human brain, on a base of traditional computer technologies is unlikely." 2 So far, all cases of practical application of artificial intelligence technologies employ "weak" or "specialized" AI, which does not have independent goal-setting and protective mechanisms that allow it to recognize the mistakes it makes. The functioning of a weak AI is a process of imitation of certain thought patterns to perform strictly defined tasks, including image recognition, speech recognition and synthesis, and the work of expert systems.

The revival of interest in AI technologies (its basic principles were formulated back in the $20^{\text {th }}$ century) is associated with the emergence of a new tool for their practical implementation - deep neural networks. ${ }^{3}$ In the most general sense, artificial neural networks are computing systems that use the functioning principles of biological neural networks. They have an information input layer, a hidden processing layer and an output layer which presents the result of the work. A distinctive feature of deep neural networks is the use of several hidden layers. Training of neural networks is carried out by different methods, but it comes down to processing of the incoming labeled data that has been prepared by a machine learning specialist. For example, if a neural network is created for image recognition, the training set will have "object" and "no object" labels.

The main factors affecting the possibility of building such networks and, accordingly, the work of a weak AI (speed of obtaining a result, and its quality) are: availability of highly qualified specialists who prepare and train the AI system; availability of an extensive amount

\footnotetext{
${ }^{1}$ Chairman of the Council on priority of scientific and technological development strategy of the Russian Federation "Transition to digital, intellectual production technologies, robotic systems, new materials and methods for designing, creation of systems for processing big data, machine learning and artificial intelligence."

2 Kalyaev, I., 'Artificial Intelligence: Whither goest thou?], Ekonomicheskie strategii, 2019, issue 5, p. 11 [in Russian]

3 Vizil'ter, Y., 'A strong AI - successor of humanity. Part 2', Portal "Scientific Russia”, 1 Feb. $2020<$ https://scientificrussia.ru/articles/silnyj-iskusstvennyjintellekt-naslednik-chelovechestva-chast-2 $>$ [in Russian].
} 
of accumulated data for training; availability of high-performance computing. With these factors in mind, some of the problems associated with mass AI technology are obvious. First, there are difficulties in forming comprehensive training samples and in conducting training as such. Secondly, there is a problem of obtaining high-quality data "bad" data can disrupt the learning process and even create a "cognitive backdoor" in the AI - an abnormal response to a certain set of input data. Third, since at their core AI systems are computing hardware and software, they are vulnerable to malicious cyber effects. We cannot rule out the rise of qualitatively new, cognitive, threats aimed at malicious use of flaws in the algorithms of artificial intelligence. It is also possible to predict the appearance of hybrid threats - cyber attacks can serve as a means of intrusion, feeding specially prepared information to the AI input, which will lead to disruption in its work.

Therefore, the existing methods and means of protection against "traditional" cyber threats will no longer be sufficient for ensuring cyber security of artificial intelligence systems. Hence, it is necessary to understand the capabilities and parameters of "cognitive effect weapons" and develop methods and means of protection against them. It is clear that the level of security against cyber attacks is influenced by a number of factors: the use of commercial publicly available products, and/or imported element base, as well as software; connection of the facility to public information networks; the level of computer literacy and "cyber hygiene" of the personnel. We also cannot rule out the existence of embedded or recruited informers and agents (so-called "insiders") who can provide information about the functioning of ICT systems and even introduce malicious software into them. At the same time, military networks and systems are no less likely to contain vulnerabilities than civilian ones. For example, according to available information ${ }^{4}$, critical cyber vulnerabilities were found in almost all major U.S. arms and military equipment procurement programs that were tested during the period of 2012-2017.

${ }^{4}$ U.S. Government Accountability Office (GAO), 'Weapon Systems Cybersecurity - DOD Just Beginning to Grapple with Scale of Vulnerabilities', Report to Congressional Requesters, Oct. 2018 <URL: https://www.gao.gov/ assets/700/694913.pdf>. 
Turning to the problems we identified earlier, it should be emphasized that one of the most important tasks during the creation of a "weak" AI is the elimination of "bad" data that can negatively affect the learning process. Experiments with image recognition systems have demonstrated how the smallest changes in the processed image can radically affect the result. ${ }^{5}$ When training a deep neural network, specialists use the so-called "loss function", which indicates by how much the results of the algorithm's work differ from real data. The rule is the more data is used in training, the more accurately the system works; but since it is impossible to process an infinite amount of information, it is impossible to check the work of AI in all imaginable conditions. This can become a significant obstacle to its military use.

Another obstacle to the use of AI in this area may be the difficulty of verification (and if international regulatory agreements are developed, of control) of whether a particular AI contains the fundamental principles of international humanitarian law (IHL) - proportionality, humanity, non-discrimination. This problem stems from a characteristic of how deep neural networks work, known as the "black box" effect. Therefore, one of the emerging areas of AI research is the creation of such auxiliary mechanisms that will allow the system operator to understand why the AI made a particular decision. For example, such a project called "Explainable Artificial Intelligence" is being conducted by the Defense Advanced Research Projects Agency (DARPA). ${ }^{6}$ The program aims to develop machine

\footnotetext{
5 See: Heaven, D., 'Why deep-learning AIs are so easy to fool', Nature, 9 Oct. 2019 $<$ https://www.nature.com/articles/d41586-019-03013-5>;Nguyen, A., Yosinski, J., and Clune, J., 'Deep Neural Networks are Easily Fooled: High Confidence Predictions for Unrecognizable Images', Computer Vision and Pattern Recognition (CVPR '15), IEEE, $2015<$ https://arxiv.org/pdf/1412.1897.pdf>; Matsakis, L., 'Researchers Fooled a Google AI Into Thinking a Rifle Was a Helicopter', Wired, 20 Dec. $2017<$ https://www.wired.com/story/ researcher-fooled-a-google-ai-into-thinking-a-rifle-was-a-helicopter/>. 6 Turek, M., 'Explainable Artificial Intelligence (XAI)', DARPA $<$ https://www. darpa.mil/program/explainable-artificial-intelligence $>$.
} 
learning methods that will allow the creation of more explicable models while maintaining a high level of learning efficiency, as well as provide the ability to effectively manage the emerging generation of AI.

Summarizing the above, we can identify the following challenges and threats related to AI technology:

- existing technologies do not allow creation of a truly thinking artificial intelligence, but only imitate the processes of solving highly specialized tasks. AIs are greatly vulnerable at the training stage, which imposes special requirements on the control of this process;

- it is impossible to carry out an absolute training and guarantee regular operation under every possible condition;

- it is impossible to verify the internalization of particular work restrictions by the AI;

- AI is susceptible to cyber and cognitive effects.

\section{The application level}

Scenarios for military use of AI can be divided into two groups: in the first group, the AI will itself make decisions according to established criteria; and in the second, the AI product will be the processed information transferred to the operator for decision-making.

An important characteristic of combat systems with AI elements is the degree of autonomy - the ability to make independent decisions based on specified criteria. It can range from the intellectualization of certain functions, while maintaining the key role of the operator, to independent decision making. The United States has adopted a threetier classification of combat systems autonomy:

- autonomous - a weapons system that, once activated, can select and engage targets without further intervention by a human operator;

- human-supervised autonomous weapons system - an autonomous weapons system that is designed to provide human operators with the ability to intervene and terminate engagements, including in the event of a weapons system failure; 
- semi-autonomous - a weapons system that, once activated, is intended to only engage individual targets or specific target groups that have been selected by a human operator ${ }^{7}$.

Evidently, the higher the level of autonomy, the more pronounced are its advantages and disadvantages. For example, the autonomy of intelligent combat systems can reduce the likelihood of errors associated with intrinsic physical limitations of human operator (reaction speed, accounting for all inputs, fatigue and unpredictability in a stressful situation). At the same time, the risks of different kind of errors increase - they are attributable to acquisition, perception and processing of data by the AI. These risks should be taken into account when developing possible scenarios for the use of AI in the military sphere.

Despite the fact that scenarios for the military use of AI have already been outlined, its combat effectiveness is yet to be assessed. First, one of such scenarios is the creation and use of lethal autonomous weapons - various UAVs, robotic ground vehicles and devices designed to operate in other environments (this also includes autonomous systems designed for carrying out cyberattacks). ${ }^{8}$ Their use brings forth the challenge of determining responsibility for actions performed by LAWS and other intellectualized systems, as well as verifying the implementation of IHL provisions. In the future, the danger of malicious takeover of autonomous objects should be seriously considered, especially with regard to actors who are not guided by the rules of IHL (such as terrorist and rebel groups). At this stage, it remains to be seen whether the AI will be able to recognize a takeover attempt and whether certain defenses will be introduced into it. Finally, a significant future challenge is the dehumanization of conflicts through the use of AI. This issue has been repeatedly raised by experts - in particular, the 2010 report of Philip Alston, UN Special

7 Department of Defense Directive 3000.09, Incorporating Change 1, 'Autonomy in Weapons Systems', 21 Nov. 2012, U.S. Department of Defense, 8 May 2017, pp. 13-14<https://fas.org/irp/doddir/dod/d3000_09.pdf >.

8 See: Kaloudi, N., and Li, J., 'The AI-Based Cyber Threat Landscape: A Survey', ACM Computing Survey, 2020, vol. 53, no. $1<\mathrm{https} / / \mathrm{dl} . \mathrm{acm}$. org/doi/ fullHtml/10.1145/3372823>. 
Rapporteur on Extrajudicial, Summary or Arbitrary Executions, says the following: "...because operators are based thousands of miles away from the battlefield, and undertake operations entirely through computer screens and remote audio-feed, there is a risk of developing a "Playstation" mentality to killing. States must ensure that training programs for drone operators who have never been subjected to the risks and rigors of battle instill respect for IHL and adequate safeguards for compliance with it" $"$.

This thesis is articulated more clearly in a book titled "Military Ethics and Emerging Technologies" by T. Demi, J. Lucas and B. Strowser: “...cognitive dissonance will weaken the operator's will to fight justly... e.g. operators not taking the warfare as 'real' or serious enough, but instead viewing it as a video game..."10 If such issues can arise today for an operator who at least sees what is happening, then what will happen with further development of autonomous weapons, when he or she will only issue a command for an attack and, perhaps, will not even see its victims? It seems that a simple requirement to have a human in the decision-making chain (in particular, with regard to the decision to use lethal force) will not be enough to solve this issue.

Another set of issues in the military use of AI is the intellectualization of systems that ensure strategic deterrence. So far, no country has demonstrated an increase in the effectiveness of information and control systems of strategic nuclear forces through the exploitation of AI technologies. Therefore, an assessment of the impact of intellectualization and autonomization on the level of strategic stability can only be hypothetical. First of all, AI technologies are expected to help compensate for the reduction in decision-making time. An automated intelligent system is capable of processing a significant amount of information in a short time, which a human operator is not capable of, and provides optimal options for action.

9 UN General Assembly, 'Report of the Special Rapporteur on extrajudicial, summary or arbitrary executions, Philip Alston, 28 May 2010’, document A/ HRC/14/24/Add.6, p. 25 <https://documents-dds-ny.un.org/doc/UNDOC/GEN/ G10/137/53/pdf/G1013753.pdf>.

10 Demy, T.J., Lucas Jr., G.R., and Strawser, B. J. Military Ethics and Emerging Technologies (Routledge: New York, 2016), p. 115. 
Within the framework of launch-on-warning strategy, an increase in situational awareness of a hypothetical attack, and of the quality of data analysis from sensors of missile attack early warning systems (EWS) can help to strengthen strategic stability, since it will reduce the risk of an erroneous reaction. At the same time, improved awareness can also create an opportunity to engage previously invulnerable targets and thereby increase the incentives for a nuclear first strike. ${ }^{11}$ The use of AI to improve the effectiveness of the defensive side's missile defense would increase the survivability of retaliatory weapons. Increasing the effectiveness of the missile defense system of the aggressor side would reduce the damage from the enemy's retaliatory strike. Most importantly, with excessive autonomy of command and control complexes (the so-called "dead hand" system), there will be a threat of a nuclear exchange and a global catastrophe due to a technical error in AI, from which no technology is immune.

To summarize the above, we can identify the following challenges and threats related to AI application scenarios:

- a general challenge is to choose a sufficient but safe degree of autonomy for each of them;

- another challenge is to identify and classify errors in the work of $\mathrm{AI}$ - both in autonomous mode and in tandem with an operator;

- a high degree of autonomy may further dehumanize conflicts;

- autonomization of systems ensuring strategic deterrence can lead to unpredictable changes in the overall system of strategic stability and, as a consequence, to serious threats to international peace and security. Therefore, this process requires special consideration and study.

${ }_{11}$ National Security Commission on Artificial Intelligence, Interim Report, 2019, p. $11<$ https://drive.google.com/file/d/153OrxnuGEjsUvlxWsFYauslwNeCEkvUb/ view $>$. For an overview of some of the works on this issue - see Ibid. 


\section{The policy level}

A review of AI strategies shows that over 20 states and organizations have in one form or another adopted AI policies. ${ }^{12}$ They all attach great importance to the development of AI technologies and their applications. At the same time, when considering the issues of military use of AI, plans of the United States, China and Russia capture the most attention $^{13}$.

The United States has been developing this area since at least 2016, when the report entitled "Preparing for the Future of Artificial Intelligence" was published, and today the relevant policies have already undergone a certain evolution. The document notes that "the United States, a leader in AI R\&D, can continue to play a key role in global research coordination through government-to-government dialogues and partnerships". ${ }^{14}$ Department Of Defense Artificial Intelligence Strategy, which came out in 2018, pointed out that to ensure security and advance the competitiveness of the United States, it is necessary to seize "the initiative to lead the world in the development and adoption of transformative defense AI solutions." ${ }^{\prime 15}$ However, most relevant are the documents of the National Security Commission on Artificial Intelligence, established in 2018 pursuant to Paragraph 1051 of John McCain National Defense Authorization Act for Fiscal Year 2019

12 Dutton, T., 'An Overview of National AI Strategies', Medium, 28 Jun. 2018 $<$ https://medium.com/politics-ai/n-overview-of-national-ai-strategies-2a70ec6edfd $>$. 13 Franke, U. E., 'Not smart enough: the poverty of European military thinking on artificial intelligence', European Council on Foreign Relations, Dec. 2019, p. 2 $<$ https://www.ecfr.eu/page/-/Ulrike_Franke_not_smart_enough_AI.pdf $>$.

${ }^{14}$ Executive Office of the President National Science and Technology Council Committee on Technology, Preparing for the Future of Artificial Intelligence (National Science and Technology Council Committee on Technology: Washington, DC, Oct. 2016), p. $35<$ https://obamawhitehouse.archives.gov/sites/default/files/ whitehouse_files/microsites/ostp/NSTC/preparing_for_the_future_of_ai.pdf $>$. 15 U.S. Department of Defense, 'Summary of the 2018 Department Of Defense Artificial Intelligence Strategy: Harnessing AI to Advance Our Security and Prosperity', 2018, p.17 <https://media.defense.gov/2019/Feb/12/2002088963/-1/-1/1/ SUMMARY-OF-DOD-AI-STRATEGY.PDF>. 
(PL 115-232 ${ }^{16}$ ). In November 2019, an interim report of the Commission was released, where "erosion of U.S. military advantage" was identified as one of the threats posed by the use of AI. It follows from these quotes that today, unlike in 2016, the United States is concerned about its leadership in AI, and the development of these technologies in other countries can undermine America's military superiority.

Although such strategies have not been published in Russia and China, the available facts indicate that these states are very interested in the military use of AI. In October 2019, Russia presented the National Strategy for the Development of Artificial Intelligence for the period up to 2030, which does not directly address the issue of military application of AI and does not express intent for an absolute leadership in this area. It notes that "the Russian Federation has significant potential to become one of the international leaders in the development and use of artificial intelligence technologies." 17 The Russian Ministry of Defense annually holds interdepartmental conferences under the heading "Artificial Intelligence Technologies for the Defense and Security of the State". The main goal of these events is to improve the framework for implementation of artificial intelligence technologies in the development of advanced automated military systems ${ }^{18}$.

China announced its claim for AI leadership in 2017 when it adopted a respective long-term strategy. The document highlights certain indicators that should be achieved in stages - by 2020, 2025 and 2030. It is stated that "by 2030, China's AI theories, technologies, and applications should achieve world-leading levels, making

16 115th Congress (2017-2018), 'H.R.5515 - John S. McCain National Defense Authorization Act for Fiscal Year 2019', 13 Aug. 2018, Section 1051, p. $328<$ https:// www.congress.gov/115/plaws/publ232/PLAW-115publ232.pdf $>$.

17 Decree of the President of the Russian Federation No. 490, October 2019 'On the development of Artificial Intelligence in the Russian Federation', para. 13 $<$ https://www.garant.ru/products/ipo/prime/doc/72738946/> [in Russian]. 18 ' 3 rd Conference on Artificial Intelligence will be held at the Army-2019 Forum', Ministry of Defense of the Russian Federation, 27 Jun. $2019<$ https://function.mil. ru/news_page/country/more.htm?id=12238706\%40egNews $>$ [in Russian]. 
China the world's primary AI innovation center..."19 With regard to the military use of AI, the Strategy notes that new generation artificial intelligence technologies should be used to support command and decision-making, military analysis, defense equipment, and other applications.

Leadership aspirations in AI development and application in the military sphere expressed by some nations can provoke an arms race between the leading global powers in a specific new environment of military confrontation. This would become a major challenge to international security, which has already been recognized by some countries. For example, the document entitled "Artificial Intelligence in Support of Defense", prepared by the French Defense Ministry's AI Task Force, categorizes countries and alliances by level of AI capability. It says the following: "Two superpowers, the U.S.A. and China, beyond the reach of other nations, each of which controls a vast mass of data, has an ecosystem based on powerful, global integrators... and is in a position to use its scientific and financial resources to further increase its domination" 20 .

In addition to the possible provocation of an arms race, the current situation is dangerous because at the moment there are no internationally recognized legal mechanisms for regulating the use of AI in the military sphere. The Guiding Principles that were developed by the UN Group of Governmental Experts (GGE) on Emerging Technologies in the Area of Lethal Autonomous Weapons Systems

19 Webster, G., Creemers, R., Triolo, P., and Kania, E., 'Full Translation: China's 'New Generation Artificial Intelligence Development Plan' (2017)', New America, 1 Aug. 2017, para. 3 (Strategic objectives) < https://www.newamerica.org/ cybersecurity-initiative/digichina/blog/full-translation-chinas-new-generationartificial-intelligence-development-plan-2017/>.

${ }^{20}$ Report of the AI Task Force September 2019, 'Artificial Intelligence in Support of Defense', p. 7 <https:/www.defense.gouv.fr/content/download/574495/9841172/ Report $\% 2520$ of $\% 2520$ the $\% 2520$ AI\%2520Task\%2520Force\%2520September $\% 25202019 . p d f>$. 


\section{Table 1. Comparison of the positions of Russia and the United States on the regulation of the use of LAWS.}

\author{
U.S.A. - from "Implementing International \\ Humanitarian Law in the Use of Autonomy \\ in Weapon Systems ${ }^{\prime a}$ \\ “(a) Existing IHL, including \\ the requirements of distinction, \\ proportionality, and precaution, provides a \\ comprehensive framework to govern the use \\ of autonomy in weapon systems".
}

“(b) Internal procedures for review and testing, including the legal review of weapons, are essential to implementing IHL requirements".

“(c) Emerging technologies in the area of LAWS could strengthen the implementation of IHL by, inter alia, reducing the risk of civilian casualties, facilitating the investigation or reporting of incidents involving potential violations, enhancing the ability to implement corrective actions, and automatically generating information on unexploded ordnance".
Russia-from "Potential opportunities and limitations of military uses of lethal autonomous weapons systems"

p.4 "6. Existing international law, including IHL, contains a number of important restrictions that fully apply to highly automated weapons systems and do not need to be modernized or adapted to the specific features of such means". This includes both the principles of proportionality, discrimination, and precaution, and that the decision on whether and how to use LAWS is made by a person.

p. 5 "8. Article 36 of 1977 Additional Protocol I (AP I) to the Geneva Conventions of 1949 is a supplementary tool to regulate LAWS in the context of future military uses".

p. 4 " 2 ...such systems are capable of considerably reducing the negative consequences of the use of weapons related to operator's errors, mental and physiological state, as well as ethical, religious or moral stance in the IHL context. The use of highly automated technology can ensure the increased accuracy of weapon guidance on military targets, while contributing to lower rate of unintentional strikes against civilians and civilian targets".

${ }^{a}$ Group of Governmental Experts on Emerging Technologies in the Area of Lethal Autonomous Weapons Systems, 'Implementing International Humanitarian Law in the Use of Autonomy in Weapon Systems', document CCW/GGE.1/2019/ WP.5, 28 Mar. $2019<$ https://www.unog.ch/80256EDD006B8954/(httpAssets)/ B2A09D0D6083CB7CC125841E0035529D/\$file/CCW_GGE.1_2019_WP.5.pdf>. ${ }^{b}$ Group of Governmental Experts on Emerging Technologies in the Area of Lethal Autonomous Weapons Systems, 'Potential opportunities and limitations of military uses of lethal autonomous weapons systems', document CCW/GGE.1/2019/ 
WP.1, 15 Mar. $2019<$ https://www.unog.ch/80256EDD006B8954/(httpAssets)/ B7C992A51A9FC8BFC12583BB00637BB9/\$file/CCW.GGE.1.2019.WP.1_R+E. pdf>.

c Article 36 "New weapons" of the Additional Protocol I (AP I) to the Geneva Conventions of 1949 states: "In the study, development, acquisition or adoption of a new weapon, means or method of warfare, a High Contracting Party is under an obligation to determine whether its employment would, in some or all circumstances, be prohibited by this Protocol or by any other rule of international law applicable to the High Contracting Party." $<$ https://www.icrc.org/en/doc/assets/ files/other/icrc_002_0321.pdf>.

can be considered closest in spirit and meaning to such mechanisms. ${ }^{21}$ Although these Principles have been agreed upon and adopted by consensus, an overview of GGE internal work reveals significant differences in the approaches of states. The ultimate goal of some countries is to prohibit the use of LAWS, while others are in favor of regulating this area. The United States, Russia, and China positively evaluate the work of the GGE and the developed Principles, which provides some grounds for optimism; moreover, the countries share similar positions on some issues, which in the future could become the basis of an agreement defining the "rules of the game" in the field of military use of AI. The concurring views (featured in Table 1) are contained in the documents submitted by the United States and Russia in spring 2019, ahead of another GGE meeting.

Such commonality of approaches on specific issues is undoubtedly a positive factor. However, it follows from paragraph 1 of the table that both parties do not consider it necessary to conclude new agreements. In addition to this, the Russian position states that "...the concerns regarding LAWS can be addressed through faithful implementation of the existing international legal norms."

\footnotetext{
21 'Report of the 2019 session of the Group of Governmental Experts on Emerging Technologies in the Area of Lethal Autonomous Weapons Systems', document CCW/GGE.1/2019/3, 25 Sep. 2019, Annex IV <https://undocs.org/en/CCW/ GGE.1/2019/3>.
} 
The Chinese position has significant differences. A statement made in the fall 2019 of the UN First Committee at a thematic meeting on conventional arms control reads as follows: "China attaches great importance to the humanitarian, legal and ethical concerns caused by Lethal Autonomous Weapon Systems (LAWS), and supports in-depth discussions on LAWS within the framework of CCW. Although LAWS is a concept of future weapons yet non-existent, China believes that it is necessary to reach an international legally-binding instrument on fully-autonomous lethal weapon systems in order to prevent automated killing by machines. All parties should first reach an agreement on the issues such as the definition and scope of LAWS"22.

The foregoing allows us to conclude that at the moment the socalled "soft law" is being formed in the field of regulation of LAWS (and, indirectly, of systems with AI). The adoption of non-binding Guiding Principles by consensus and their subsequent development points to that. At the same time, various states see the ultimate goal of the GGE differently. China, as already noted, seeks to create a new legally meaningful mechanism, while Russia and the United States consider the existing array of IHL sufficient to regulate LAWS. We require clarifications of the modality "for applying the existing international legal restrictions and IHL rules to these systems". This suggests that we are unlikely to witness development of special multilateral international legal mechanisms in the field of LAWS in the near future. Such an agreement could resolve some important issues in the use of autonomous weapons, in particular, the problem of monitoring compliance with the principles of IHL. It can be assumed that in the future such an agreement will be implemented at a bilateral level, in particular, between the United States and Russia, since their vision of the problem as a whole overlaps at various points. However, this will become possible only if both sides recognize it.

22 'Statement of the Chinese Delegation at the Thematic Discussion on Conventional Arms Control at the First Committee of the 74th Session of the UNGA', New York, Oct. 2019, p. 3 <https://www.un.org/disarmament/wpcontent/uploads/2019/11/statement-by-china-conventional-weapons-english-cwoct-25-19.pdf>. 
$* * *$

Many developed countries of the world conduct active research in the field of artificial intelligence, and new developments in this area are already being applied in the military and civilian spheres. In the future, it can be expected that AI will be even more widely applied in all spheres of public life and will contribute to economic and social development. At the same time, AI is a source of new challenges and threats at the level of technology, military applications and in the field of international politics.

Existing technologies do not yet allow creation of a truly "thinking" artificial intelligence, but only imitate the processes of solving highly specialized tasks. This does not guarantee regular functioning of the systems under all conditions and also complicates the verification of the imposed restrictions. In addition, since military intelligence systems are computing hardware and software systems, they are vulnerable to cyber and cognitive threats that can be used by a potential adversary.

A significant challenge to the military application of $\mathrm{AI}$ is to determine the range of tasks in which its safe use can be guaranteed. For instance, the autonomy of systems ensuring strategic deterrence can lead to unpredictable changes in the overall system of strategic stability, and therefore this issue requires special consideration and study. Another challenge at the level of application is dehumanization of conflicts when using LAWS, which is likely to worsen as the level of autonomy increases.

At the level of policy, individual states strive for leadership in the development and implementation of AI, including in the military sphere, which provokes an arms race and undermines international security. The issues are exacerbated by the lack of international mechanisms for regulating the use of AI in the military sphere. At the same time, within the framework of the UN Group of Governmental Experts on Emerging Technologies in the Area of Lethal Autonomous Weapons Systems, we can see a commonality of approaches to the problems under consideration among some of the most important states, which in the future may pavethe way to concluding regulatory 
bilateral agreements. In general, it should be noted that developed states should balance their ambitions to use AI in the military sphere with recognition and comprehension of new challenges and threats posed by these technologies. Otherwise, the use of incompletely developed technological advances can lead to unpredictable and threatening consequences for international security. 


\section{PART II. EXPERT INSIGHTS}

6. Arctic in the high politics

7. Middle East conflicts: correlation between local and regional factors

8. The Indo-Pakistani mutual deterrence: strategic culture and nuclear strategy

9. Transformation of the Islamic State 


\section{ARCTIC IN THE HIGH POLITICS}

\section{Andrei ZAGORSKI and Andrei TODOROV}

In the context of the crisis in the Russia-West relations, the Arctic remains a rare exception from the overall confrontation. Despite the suspension of military-political cooperation with Russia by the Western states, scaling down of joint offshore oil and gas projects, and financial sanctions, constructive collaboration continues within the framework of the Arctic Council (AC) and on other platforms. In 2015-2018, a number of important decisions related to the regional cooperation were adopted. ${ }^{1}$

Experts have questioned how long the Arctic could be kept immune from the impacts of the high politics. ${ }^{2}$ Against the backdrop of the Russian and NATO's military activity increase in the area adjacent to the North Atlantic, the discussions of the threats related to militarization of the region have resumed. ${ }^{3}$ There has been a pervading sense of political uncertainty about the future developments. ${ }^{4}$

\footnotetext{
${ }^{1}$ For examples of such decisions see, in particular: Zagorski, A., 'Security in the Arctic', Moscow, IMEMO, 2019, pp. 11-12 [In Russian].

${ }^{2}$ See, for example: Blakkisrud, H., 'Introduction: Can Cooperative Arctic Policies Survive the Current Crisis in Russian- Western Relations?', Arctic Review on Law and Politics, 2018, vol. 9, pp. 377-381.

${ }^{3}$ See: 'Interview of the Ambassador At Large of the Russian Foreign Ministry N. Korchunov to the international news agency 'Rossiya Segodnya", Ministry of Foreign Affairs of Russian Federation, 29 Nov. $2019<$ https://www.mid.ru/ ru/foreign_policy/rso/-/asset_publisher/0vP3hQoCPRg5/content/id/3925387>; Frederiksen, C.H., 'Danish Defence in the midst of change', in: Danish Foreign Policy Review 2019, eds. K. Fischer, H. Mouritzen, Copenhagen, Danish Institute for International Studies, 2019, p. 37; Klare, M.N., 'A World War Could Break Out in the Arctic', The Nation, 2 Nov. $2020<$ https://www.thenation.com/article/world/ nato-russia-norway/>.

${ }^{4}$ Report to Congress 'Department of Defense Arctic Strategy', Washington, DoD, 2019, p. $4<$ https://media.defense.gov/2019/Jun/06/2002141657/-1/1/1/2019-DOD-ARCTIC-STRATEGY.PDF>; 'Intelligence Risk Assessment 2017. An assessment of developments abroad impacting on Danish security',
} 
In 2019, the problems that accumulated for years became more visible. The issues that until recently did not give cause for concern have returned to the agenda. The assertion by the U.S. Administration of an increasing confrontation with China and Russia, which formed the basis of the U.S. National Security Strategy, was extended to its Arctic policies in 2019. The fading interest of the current administration in the environmental agenda and particularly in the problem of climate change has narrowed the space for cooperation on these key issues of the AC agenda. In May 2019, during the Ministerial Meeting of the Council in Rovaniemi, Finland, the participants failed to adopt the final declaration for the first time in over twenty years. ${ }^{5}$

In March 2020, the "Basics of the State Policy of the Russian Federation in the Arctic for the Period until 2035" were enacted. The document does not overdramatize the situation in the region. The emphasis is put on ensuring the sovereignty and territorial integrity of Russia, maintaining the Arctic as the territory of peace, stable and mutually beneficial partnership; providing a high quality of life and well-being for the population of the Arctic Zone of the Russian Federation (AZRF), developing the AZRF as the key strategic resource base of the country; protecting the Arctic environment, as well as the native habitat and traditional way of life of indigenous peoples. ${ }^{6}$ In May 2020, the Ministry of the Far East and the Arctic introduced a draft of the Strategy of the Development of the Arctic Zone of the Russian Federation and Ensuring of National Security for the Period until 2035, setting out the key activities and goals for developing the AZRF, mechanisms, stages, and expected outcomes.

Copenhagen, Danish Defence Intelligence Service, 2017, p. $43<$ https://fe-ddis. $\mathrm{dk} /$ SiteCollectionDocuments/FE/EfterretningsmaessigeRisikovurderinger/ Risikovurdering2017_EnglishVersion.pdf>.

${ }^{5}$ Koivurova, T., 'Is This the End of the Arctic Council and Arctic Governance as We Know It?', High North News, 12 Dec. 2019 <https://www.highnorthnews.com/ en/end-arctic-council-and-arctic-governance-we-know-it>.

6 'Basics of the State Policy of the Russian Federation in the Arctic for the Period until 2035', approved by the Decree of the President of the Russian Federation № 164, 5 Mar. $2020<$ http://docs.cntd.ru/document/564371920)> [In Russian]. 7 Monitoring of the social-economic development of the Arctic Zone of Russia, vol. 52, 2020, p. 2 [In Russian]. 
Despite an overall measured approach of these documents, a number of Russian legislative initiatives have been the subject of critical review over the recent years. They are used or can be used to underscore the assertion of ongoing confrontation between the United States and Russia in the Arctic, prompting concerns about increased U.S.-Russia tensions in the region. As a result, other states face a difficult choice between continuing the policies aimed at maintaining stability in the region and cooperating with Russia, on the one hand, and expressing solidarity with the U.S., on the other. ${ }^{8}$

In our opinion, the current negative trends narrowing opportunities for international cooperation in the Arctic are not irreversible. However, overcoming them will require Russia to make balanced choices based on comprehensive discussions with the other states in the region.

\section{Competition in the Arctic?}

The 2017 National Security Strategy of the United States of America is based on the premise of growing competition with China and Russia and the failure of the previous policies based on "engaging" these countries. ${ }^{9}$ This decision entails long-term consequences. In particular, the U.S. Navy has not just moved into its deep modernization phase within the framework of the Third Offset Strategy, adopted under

\footnotetext{
8 'Intelligence Risk Assessment 2019. An assessment of developments abroad impacting on Danish security', Copenhagen, Danish Defence Intelligence Service, 2019, p. $12<$ https://fe-ddis.dk/SiteCollectionDocuments/FE/ EfterretningsmaessigeRisikovurderinger/Intelligence $\% 20$ Risk $\% 20$ Assessment $\% 20$ 2019.pdf>.

9 National Security Strategy of the United States of America, Washington, The White House, 2017 <https://www.whitehouse.gov/wp-content/uploads/2017/12/ NSS-Final-12-18-2017-0905.pdf $>$.
} 
the Obama Administration, ${ }^{10}$ but under the current National Security Strategy prepares for the engagement with the major naval powers primarily, China. ${ }^{11}$

There has been little reference to the Arctic in the strategic documents adopted by the U.S. over the past few years. Against the general backdrop of national security priorities, the region remains at the periphery for Washington in terms of non-strategic military activities. In the National Intelligence Council's report on Global Trends, the Arctic was addressed in the context of global climate change rather than as one of potential theaters of confrontation between global powers. ${ }^{12}$ The 2017 National Security Strategy refers to the Arctic only once in a broad context, ${ }^{13}$ while the 2018 National Defense Strategy ${ }^{14}$ and the Recommendations of the National Defense Strategy Commission ${ }^{15}$ make no reference to it at all.

Nevertheless, in 2019 the assertion of competition with China and Russia appeared in the Department of Defense ${ }^{16}$ and the Coast Guard's ${ }^{17}$ new Arctic strategies, which set out U.S. security interests in the region based on the National Security Strategy. However, the Pentagon does not regard the Arctic as an independent field of military activity, but rather as a "corridor" connecting two key regions of potential great power competition - the Indo-Pacific and Europe. ${ }^{18}$

\footnotetext{
${ }^{10}$ Ochmanek, D., 'The Role of Maritime and Air Power in DoD's Third Offset Strategy', RAND Corporation Testimony, Dec. 2014.

11 'Cancian, M.F., 'U.S. Military Forces in FY2020. Navy', Washington, CSIS, 2019, pp. 5, 8. 10-12.

12 'Global Trends. Paradox of Progress', Washington, National Intelligence Council, $2017<$ https://www.dni.gov/files/documents/nic/GT-Full-Report.pdf>.

13 National Security Strategy of the United States of America..., p. 40.

14 Summary of the National Defense Strategy, 'Sharpening the American Military's Competitive Edge', Washington, DoD, 2018.

15 'Providing for the Common defense. The Assessment and Recommendations of the National Defense Strategy Commission', Washington, USIP, 2018.

16 Report to Congress 'Department of Defense Arctic Strategy'..., pp. 1-5.

17 United States Coast Guard Arctic Strategic Outlook, Washington, USCG, 2019, p. $4<$ https://safety4sea.com/wp-content/uploads/2019/04/USCG-Arctic-StrategicOutlook-2019_04.pdf $>$.

18 Report to Congress 'Department of Defense Arctic Strategy'..., p. 5.
} 
State Secretary Mike Pompeo stressed the competition with China and Russia in the Arctic in his speech just before the opening of the Ministerial Meeting of the AC in Rovaniemi on 6 May 2019.19 The appearance of this premise in the U.S. Arctic-related policies has not yet led to decisions that would change the old very modest U.S. plans concerning military posture in the Arctic. Just like in the strategic documents of 2013 and 2016, the Pentagon assumes that there are no direct military threats to the country in the region. ${ }^{20}$ The U.S. Navy in its recent documents has emphasized that a conflict in the region is unlikely $^{21}$ and, despite the pressure from the Congress, consistently rejects the idea of building special warships designed and equipped for polar waters. ${ }^{22}$ All discussions ultimately come down to the need of building new icebreakers for the U.S. Coast Guard. ${ }^{23}$

Building of polar class warships for the Navy is not only considered too expensive but also unjustifiable in the face of harsh climate conditions, lack of required coastal infrastructure and increasing challenges caused by climate change, making most of the Arctic Ocean inaccessible for surface naval operations currently and for the foreseeable future. ${ }^{24}$ Only the Northern Fleet has carried out annual voyages to the "real" Arctic, starting from the 2012 navigation

19 Pompeo, M.R.., 'Looking North: Sharpening America’s Arctic Focus: Remarks', 6 May 2019, Rovaniemi, Finland, U. S. Department of State, 6 May, $2019<$ https:// www.state.gov/looking-north-sharpening-americas-arctic-focus/>.

20 Report to Congress 'Department of Defense Arctic Strategy'..., p. 3.

21 'Arctic Planning. Navy Report to Congress Aligns with Current Assessments of Arctic Threat Levels and Capabilities Required to Execute DOD's Strategy', United States Government Accountability Office, Report to Congressional Committees, November 2018, p. $10<$ https://www.gao.gov/assets/700/695312.pdf>.

22 'Navy Force Structure and Shipbuilding Plans: Background and Issues for Congress', Congressional Research Service, RL32665, 19 Nov. 2019, p. 39.

23 'Memorandum on Safeguarding U.S. National Interests in the Arctic and Antarctic Regions', The White House, 9 Jun. $2020<$ https://www.whitehouse.gov/ presidential-actions/memorandum-safeguarding-u-s-national-interests-arcticantarctic-regions $>$.

24 Report to Congress 'Department of Defense Arctic Strategy'..., p. 3-4. 
season. ${ }^{25}$ Limited capabilities for patrolling of the coastal Arctic waters for several months a year can be acquired only by Canada as a result of implementation of the much delayed program of building the Arctic Offshore Patrol Ships, capable of operating in first-year ice. ${ }^{26}$

In 2011, the Pentagon pointed out that only a major environmental or human disaster or activity viewed as threatening U.S. interests in the Arctic could cause revision of the restrained U.S. policies in the region and the decision to significantly invest in the military buildup. ${ }^{27}$ The question as to what kind of event might force Washington to do this remains open.

From the scheduled defense policy reviews carried out by other coastal states (Canada, Denmark and Norway) after 2014, it is evident that their earlier calm assessments of military threats in the Arctic as low remain unchanged. Despite the discussion over the recent years, at this point these countries have not revised their modest plans for military posture in the Arctic. The most intense debate in 2015 occurred in Norway - the only NATO Arctic state sharing a land border with Russia. However, in 2016, it also resulted in abandoning the General Staff's proposals to upgrade the Norwegian Armed Forces. Instead, the decision was made to enhance the systems of early warning against possible attacks and establish infrastructure for reinforcement by NATO states' forces in the period of threat without permanently deploying them in the country. ${ }^{28}$ Since 2018 , practicing

\footnotetext{
${ }^{25}$ For a review of the annual Arctic voyages of the Northern Fleet see: Zagorski, A., 'Security in the Arctic', Moscow, IMEMO, 2019 [In Russian]. 26 'Arctic and offshore patrol ships', Government of Canada, 7 Dec. $2018<\mathrm{https}$ // www.canada.ca/en/department-national-defence/services/procurement/arcticoffshore-patrol-ships.html>.

27 'Report to Congress on Arctic Operations and the Northwest Passage', Washington, DoD, 2011, p. $12<$ https://dod.defense.gov/Portals/1/Documents/pubs/ Tab_A_Arctic_Report_Public.pdf $>$.

28 For a detailed analysis of the review of the Arctic states' defense policies 20142015 see: Zagorski, A., 'Security in the Arctic', Moscow, IMEMO, 2019, pp. 11-12, 96-103 [In Russian].
} 
NATO force movements to Norway has been at the core of multilateral exercises in Norway, although in March 2020 they were canceled due to the coronavirus pandemic. ${ }^{29}$

In 2019, the Chief of the Norwegian General Staff introduced his advice related to increased military spending and reinforcement of the Armed Forces. ${ }^{30}$ The stocktaking should be finalized in summer 2020.

Nevertheless, the increase in military activities of the United States, NATO countries, and Russia in the North Atlantic has an indirect impact on the Arctic region. In 2018, NATO approved two new commands - the Joint Support and Enabling Command and a new command for the Atlantic - to support reinforcements from the U.S. to Europe, replacing the Allied Command Atlantic abolished in 2002. In 2019, we saw the restoration of the U.S. Second (Atlantic) Fleet, which includes in its area of operations the Barents Sea and the Norwegian Sea, in addition to the vast North Atlantic region. ${ }^{31}$

In light of the resumed Russian nuclear submarines patrols in the North Atlantic, the antisubmarine Greenland-Iceland-UK Gap is being reinstated. The same logic informs the U.S. decisions related to deployment of antisubmarine aircrafts on the Keflavik base in Iceland for the first time since 2006, the refurbishment of the runway at Thule Air Base in Greenland, the decisions by Norway and Denmark to build

\footnotetext{
29 'Cold Response 2020', The Norwegian Armed Forces, 17 Apr. $2020<$ https:// forsvaret.no/en/exercise-and-operations/exercises/cold-response>.

30 'A stronger defense. The military advice of the Chief of Defence 2019’, Abridged version, Oslo, $2019<$ https://forsvaret.no/en/newsroom/ news-stories/a-stronger-defence>.

31 Larter, D.B., 'U.S. Navy declares new fleet created to confront Russia fully operational', Defense News, 31 Dec. $2019<$ https://www.defensenews.com/ naval/2019/12/31/us-navy-declares-new-fleet-stood-up-to-confront-russia-fullyoperational/>.
} 
up the antisubmarine warfare capabilities, as well as the UK decision to acquire new fleet of antisubmarine aircraft it abandoned at the end of the Cold War. ${ }^{32}$

However, the increase of NATO's activity in the North Atlantic affects the Arctic only peripherally. The Alliance focuses on establishing capabilities of military deterrence of Russia in the Baltic region, as well as on securing maritime communications in the North Atlantic. In the short-term, these decisions distract from the Arctic rather than draw attention to the region. There is no consensus within the Alliance as to the feasibility of operational and military activities in the polar region. Understanding of the need to avoid actions which could provoke Russia prevails. ${ }^{33}$

Obviously, the Russian military leadership takes this into account. While noting the greater intensity and scale of operational and combat training of the NATO Forces in this area, Commander of the Northern Fleet Admiral Alexander Moiseev in December 2019 described the military situation within the Fleet's area of responsibility as "stable and controlled". ${ }^{34}$

\footnotetext{
32 'Report to Congress on Strategy to Protect United States National Security Interests in the Arctic Region', Washington, DoD, 2016, p. $11<\mathrm{https}$ ://www. defense.gov/Portals/1/Documents/pubs/2016-Arctic-Strategy-UNCLAS-clearedfor-release.pdf >; Report to Congress 'Department of Defense Arctic Strategy'..., pp. 3, 9; Nordenman, M., 'Russian Subs Are Reheating a Cold War Chokepoint', Defense One, 4 Mar. 2016 <https:/www.defenseone.com/ideas/2016/03/ russian-subs-are-reheating-cold-war-chokepoint/126428/>.

33 Connolly, G.E, Sub-Committee on Transatlantic Relations, Report 'NATO and Security in the Arctic', NATO Parliamentary Assembly, Political Committee, 172 PCTR17 E rev.1 fin. 7.10.2017, p. $5<$ https:/www.nato-pa.int/downloadfile?filename $=$ sites $/$ default/files/2017-11/2017\%20-\%20172\%20PCTR $\% 2017 \% 20$ E\%20rev.1\%20fin\%20-\%20NATO\%20AND\%20SECURITY\%20IN\%20THE\%20 ARCTIC.pdf>.

34 'The Northern Fleet Commander noted the increase of NATO activity in the Arctic', Russian Defense Ministry, 27 Dec. $2019<$ https://function.mil.ru/news page/person/more.htm?id=12268675@egNews $>$ [In Russian].
} 


\section{Political uncertainty}

Over the recent years, the Russian Federation and other regional states have made efforts to enhance stability and predictability of the situation in the Arctic.

A sense of political uncertainty in the region was caused, in part, by doubts arising in some countries as to whether all states would comply with the 2008-2014 arrangements related to the process of establishing the outer limits of their continental shelf in the Arctic Ocean. For instance, Denmark does not rule out the possibility that Moscow may disregard the recommendations of the Commission on the Limits of the Continental Shelf (CLCS) if it considers them unacceptable; or in case the CLCS confirms the validity of the Russian claims, Russia may consider the issue resolved and take unilateral measures to establish the continental shelf limits without having to wait for the recommendations on Danish and Canadian submissions and disregarding the need to settle the delimitation issue with them. ${ }^{35}$

The meeting of the Arctic states in Ilulissat, Greenland arranged by Denmark in May 2018 was aimed at addressing the existing concerns. It reaffirmed the commitments reached in the same place in 2008 concerning an orderly political settlement of all overlapping claims on the Arctic shelf based on the 1982 UN Convention on the Law of the Sea (UNCLOS). ${ }^{36}$

\footnotetext{
35 'The DDIS Intelligence Risk Assessment 2013. An intelligence assessment of developments abroad impacting on Danish security', Copenhagen, Danish Defence Intelligence Service, 2013, p. 14-15 <https://fe-ddis.dk/SiteCollectionDocuments/ FE/EfterretningsmaessigeRisikovurderinger/Risikovurdering2013_EnglishVersion. pdf $>$; 'Intelligence Risk Assessment 2016. An assessment of developments abroad impacting on Danish security', Copenhagen, Danish Defence Intelligence Service, 2016, p. $39<\mathrm{https}$ ://fe-ddis.dk/SiteCollectionDocuments/FE/ EfterretningsmaessigeRisikovurderinger/Risikovurdering2016_EnglishVersion. pdf>; 'Intelligence Risk Assessment 2017', p. 43.

36 'Foreign Minister Sergey Lavrov's greetings to the Participants in the Event Marking the 10th Anniversary of the Ilulissat Declaration', MFA of Russia, 23 May $2018<$ http://www.mid.ru/ru/foreign_policy/news/-/asset_publisher/ cKNonkJE02Bw/content/id/3231254>; 'High-level Meeting in Ilulissat, Greenland
} 
In 2014 Russia, Denmark and Canada reached an agreement through the exchange of notes, setting out the course of action on the establishment and delimitation of the continental shelf in the Arctic Ocean. They reaffirm this arrangement in their submissions to the CLCS, as well as in the notes to the UN General Secretary in response to other state's submissions. In particular, in December 2019 the Permanent Mission of the Russian Federation to the UN sent a note confirming the agreement in response to the Canadian submission the latest of the three state's submissions to the CLCS. ${ }^{37}$

The Basics of the State Policy of the Russian Federation in the Arctic for the Period until 2035 also stress the need to continue "cooperation with the Arctic states on the issue of delimitation of the continental shelf in the Arctic Ocean, taking into account the national interests of the Russian Federation and based on the provisions of the international law and existing agreements" (emphasis added). ${ }^{38}$

These efforts certainly promote the stability and predictability of the situation in the Arctic and lower the risks of conflicts and disputes emerging in the region. Meanwhile, a number of other initiatives that are currently under consideration could, on the contrary, lead to new disputes in the Arctic. Among them are the Russian initiative to introduce a notification-based procedure for foreign warships passing through the territorial sea of the Northern Sea Route (NSR), the proposal to include the Pechora Sea, the Barents Sea and the White Sea (as well as the Bering Sea and the Sea of Okhotsk in the Far East) in the NSR water area, and the reopened discussion as to whether

on the Occasion of the 10-year Anniversary of the Ilulissat Declaration', Ministry of Foreign Affairs of Denmark, 18 May $2018<\mathrm{http}: / / \mathrm{um} . \mathrm{dk} / \mathrm{en} / \mathrm{news} /$ NewsDisplayPage/?newsID=C26BC6EE-F208-43DA-A8B6-1923A3FD5824>.

37 Currently, the submission of Denmark in respect to the Arctic continental shelf of Greenland dated 15 December, 2014, the revised submission of Russia dated 3 August, 2015, and the submission of Canada dated 23 May, 2019, are under consideration of the CLCS. For the summaries of the submissions and communications of states see: $<$ https://www.un.org/depts/los/clcs_new/ commission_submissions.htm>.

38 Basics of the State Policy of the Russian Federation in the Arctic for the Period until 2035, Para. 16 “d”. 
Russia should withdraw from the 1990 Agreement with the United States on the maritime boundary in the Bering Sea, the Chukchi Sea and the Arctic Ocean.

\section{Introduction of the notification-based procedure for foreign warships and Extension of the NSR}

In March 2019 Russia's Ministry of Defense presented to the Cabinet a draft decree introducing amendments to the Decision of the Russian Government No.1102 dated October 2, 1999 "On the Rules of Navigation and Stay of the Foreign Warships and Other State-owned Ships Operated for Non-Commercial Purposes in the Territorial Sea, the Internal Sea Waters, on the Naval Bases, the Warship Basing Locations and Sea Ports of the Russian Federation". 39 The draft proposes to institute the following rules for foreign warships and other ships enjoying immunity:

- the duty of the flag state to submit a notification concerning the planned passage through the territorial sea of the Russian Federation in the NSR water area no later than 45 days prior to the start of the proposed passage. The notification should indicate the nationality of the ships and vessels, the purpose of the voyage, the planned route, the passage timeframe, as well as military ranks and last names of the commanding officer of the unit and each ship (captains);

- mandatory ice piloting in the territorial sea and internal sea waters within the NSR boundaries;

- mandatory icebreaker assistance in the territorial sea and internal sea waters within the NSR boundaries, should there be a need warranted by the ice situation.

${ }^{39}$ Draft Decree of the Government of the Russian Federation "On amending the Rules of Navigation and Stay of the Foreign Warships and Other Stateowned Ships Used for Non-Commercial Purposes in the Territorial Sea, the Internal Sea Waters, on the Naval Bases, the Warship Basing Locations and Sea Ports of the Russian Federation" < https://regulation.gov.ru/projects/List/ AdvancedSearch\#npa=89000 $>$ [In Russian]. 
According to the Explanatory Note of the Defense Ministry, the main purpose of the amendments is to ensure the safety of navigation in these maritime areas and take measures intended to prevent, reduce, and control vessel-sourced marine pollution. ${ }^{40}$ The amendments only apply to Russia's internal waters and territorial sea of the NSR rather than its entire water area.

This initiative was apparently triggered by the passage through the NSR made by the French offshore support and assistance multipurpose vessel Rhone in September 2018. The desire of the Russian military leadership to ensure that foreign warships don't appear in the Russian Arctic waters did not go unnoticed and prompted a negative international reaction. ${ }^{41}$ In the statements of the U.S. officials and the 2019 Arctic Strategy of the Department of Defense, the Russian Defense Ministry initiative was much mythologized - with some help from the Russian media ${ }^{42}$ - through allegations that Russia was preparing to sink ships in violation of the NSR navigation rules ${ }^{43}$ despite the fact that the proposed amendments did not set out any enforcement measures against foreign warships and other vessels.

However, the criticism is generally justified. Warship immunity from the jurisdiction and interference of coastal states is one of the backbones of the international Law of the Sea. These ships enjoy immunity regardless of the category of maritime areas in which they are navigating. Even when in internal waters and the territorial

\footnotetext{
40 Explanatory note concerning the Draft Decree of the Government of the Russian Federation "On amending the Rules of Navigation and Stay of the Foreign Warships and Other State-owned Ships Used for Non-Commercial Purposes in the Territorial Sea, the Internal Sea Waters, on the Naval Bases, the Warship Basing Locations and Sea Ports of the Russian Federation" $<$ https://regulation.gov.ru/projects/List/ AdvancedSearch\#npa $=89000>$ [In Russian].

41 'Intelligence Risk Assessment 2019', p. 15.

42 See, for example: Kozachenko, A., Stepovoi, B., Bainazarov, E., 'Cold Wave: the foreigners face rules of navigation in the Northern Sea Route', Izvestia, 6 Mar. $2019<$ https://iz.ru/852943/aleksei-kozachenko-bogdan-stepovoi-elnarbainazarov/kholodnaia-volna-inostrantcam-sozdali-pravila-prokhoda-sevmorputi> [In Russian].

43 Pompeo, M.R., 'Looking North: Sharpening America's Arctic Focus: Remarks', Op. cit.; Report to Congress 'Department of Defense Arctic Strategy’.., p. 4.
} 
sea during times of peace, warships may not be seized, detained or searched by a coastal state. Like commercial vessels, warships enjoy the right of innocent passage through territorial sea unless they violate the provisions of Article 19 of UNCLOS. Otherwise, warships are exempt from the criminal and civil jurisdiction of a coastal state.

There is international practice of introducing a permissionbased or notification-based procedure for foreign warships in the territorial sea. ${ }^{44}$ China, for one, pursues such approach.$^{45}$ However, the position of Russia on this issue is found in the Joint Statement by the United States and Soviet Union related to a uniform interpretation of rules of international law governing innocent passage, dated September 23, 1989. The document sets out that all ships, including warships, enjoy the right of innocent passage through the territorial sea in accordance with international law, for which neither prior notification nor authorization is required. ${ }^{46}$ The statement makes no exceptions specifically for the Arctic waters.

The Explanatory Note of the Defense Ministry rightly points out that special rules of navigation in the NSR adopted by Russia pursuant to Article 234 of UNCLOS for the prevention, reduction and control of marine pollution from vessels in ice-covered areas cannot be applied to foreign warships and state-owned ships operated for noncommercial purposes. ${ }^{47}$ However, there are no other legal grounds for introduction of a notification-based procedure for an innocent passage of foreign warships through the Russian territorial waters.

44 Gudev, P., 'The U.S. policies in the World Ocean', International processes, 2016, vol. 14 (1), pp. 106-120 [In Russian].

45 Keyuan, Z., 'Innocent passage for warships: The Chinese doctrine and practice', Ocean Development \& International Law, 1998, vol. 29, no. 3, pp. 195-223.

46 Joint Statement by the United States and Soviet Union, with Uniform Interpretation of Rules of International Law Governing Innocent Passage, September 23, 1989, Appendices to Roach J. A., Smith W. R., 'Excessive Maritime Claims', 3rd ed., Leiden, Martinus Nijhoff Publishers, Boston, 2012, p. 656.

47 Explanatory note concerning the Draft Decree of the Government of the Russian Federation (note 40). 
In case the proposed amendments are adopted, their legitimacy will be most likely contested - primarily by the U.S., but by other actors as well. Ensuring freedom of navigation has always been an essential part of the U.S. policies in general and has been stressed in every Arctic strategy since the 1970's. Until recently, the operation of the Washington's Freedom of Navigation (FON) Program in the Arctic - a demonstrative passage of warships through respective waters - has been merely declaratory. But by introducing a notificationbased procedure amid confrontational narrative in the region, Russia would invite the U.S. to conduct a FON operation in the Arctic.

Examples of such operations include Pentagon's numerous warship deployments in the South China Sea and the East China Sea to demonstrate disagreement with the Chinese claims. ${ }^{48}$ Any FON operation in the Arctic would, of course, be different from those in the South China Sea. The U.S. Navy does not have surface ice-capable ships. But a demonstrative passage through the territorial sea of the NSR without notifying the Russian authorities would not necessarily require such a ship - the Rhone did it not being an ice-strengthened ship.

Introduction of a notification-based procedure for foreign ships in the NSR, while making no references to persuasive legal grounds, can not only be harmful for the reputation of Russia as a state committed to international law, but also provoke a conflict with the U.S. virtually for no reason. This, in turn, can exacerbate the unsettled Russia-U.S. dispute related to the legal status of the NSR straits. ${ }^{49}$

The use of two terms from the Far East Ministry's proposed Strategy of the AZRF until 2035 sparked a debate at the May 2020 meeting of the Russian State Arctic Commission. The terms "the Northern Sea Route", which is limited by the Kara Gate in the west and the Bering Strait in the east, and "the Northern Sea Transport

48 'Freedom of Navigation in the South China Sea: A Practical Guide', Belfer Center for Science and International Affairs, Harvard

Kennedy School, June $2017<$ https://www.belfercenter.org/publication/

freedom-navigation-south-china-sea-practical-guide $>$.

${ }^{49}$ See: Todorov A. 'The Russia-USA legal dispute over the straits of the Northern Sea Route and similar case of the Northwest Passage', Arctic and North, 2017, no. 29 , pp. $62-75$. 
Corridor" (NSTC) - were introduced due to the different regimes regulating navigation within the NSR boundaries and beyond. The NSR waters are subject to a permission-based regulation of navigation that contains requirements for ship structural design and equipment. Beyond the NSR, these stricter rules do not apply. Whereas the concept of the NSTC implied implementation of a project of a container line from Murmansk to Kamchatka, which would include ports outside of the NSR. ${ }^{50}$

However, at the meeting the Ministry of Economy insisted on exclusion of the term "the NSTC" from the Strategy "while preserving the task of integrated development of the sea lanes and coastal infrastructure of the Barents Sea, the White Sea, the Pechora Sea in the western part of the Northern Sea Route, the Bering Sea and the Sea of Okhotsk in the eastern part". As a result, it was decided to abandon the use of the term, and the responsible agencies were requested to submit proposals to the Cabinet on amendments to the Russian Merchant Marine Code and inclusion of the "internal sea waters, territorial sea and exclusive economic zone of Russia in the Barents Sea, the White Sea, the Pechora Sea, the Bering Sea and the Sea of Okhotsk" into the NSR water area. ${ }^{51}$

If this decision implies extension of the NSR water boundaries, which fall under the permission-based regulation of navigation, it could generate a rather negative reaction, especially if we take into account the intense vessel traffic and overall negative perception by the law of the sea experts of the requirement to obtain permission for navigation in the maritime areas subject to the freedom of navigation. It could be viewed even more negatively than the above proposal on introducing a notification-based procedure for foreign warships passing through the territorial waters of the NSR, since it may involve interests of a

\footnotetext{
${ }^{50}$ See, in particular: Monitoring of social-economic development of the Russian Arctic Zone, 2020, vol. 52, p. 11-12. [In Russian].

51 'State Arctic Commission proposed to include Murmansk and Kamchatka in the Northern Sea Route', Interfax, 20 May $2020<$ https://www.interfax.ru/ russia/709492> [In Russian]. See also: 'The Northern Sea Route. The Government considers to extend the route to Sakhalin', Kommersant, 21 May 2020, № 88, p. 1 $<$ https://www.kommersant.ru/doc/4349939> [In Russian].
} 
much greater number of stakeholders. Alternatively, if it refers to purely management tasks of securing cargo traffic from Murmansk to Kamchatka, then the concept of the NSTC would be an optimal solution, with the NSR being its integral part. As for today, apparently, the Russian government is inclined to opt for preserving the boundaries of the NSR intact. ${ }^{52}$

\section{Russia's possible withdrawal from the 1990 Agreement}

In October 2019, the question of whether Russia should withdraw from the 1990 Agreement with the U.S. on the maritime boundary in the Bering Sea, the Chukchi Sea, and the Arctic Ocean was raised in the Federation Council by Senator from Kamchatka Boris Nevzorov. ${ }^{53}$ In early 2020, this was discussed in the Federation Council's committees. Since the Agreement was signed, the Russian fishermen have been the most active opponents of its ratification in Russia. ${ }^{54}$ This matter has almost a thirty-year history and it is not the first time it is being raised. The responses are also well known: if Russia withdraws, it won't gain all that much, but can lose a lot, including in the Arctic.

Russian legal scholars believe that Russia's withdrawal from the Agreement after almost thirty years of its provisional implementation would not be the best possible legal solution to a problem of limitations to Russian sovereignty and jurisdiction in the Arctic Ocean and the Bering Sea. The long-standing implementation of the Agreement first by the USSR and then Russia "created legal implications in favor of the arrangements reflected in the Agreement, whereas termination

52 'The Ministry of the Far East estimates the extension of the Northern Sea Route unfeasible', TASS, 16 Jul. $2020<$ https://tass.ru/obschestvo/8979477> [In Russian].

53 'Matvienko: it is time to adopt symmetrical measures, if the Russian interests are violated', Vmeste-RF, Federation Council's TV media, 9 Oct. $2019<\mathrm{https}: / /$ vmeste-rf.tv/news/matvienko-it-s-time-to-take-symmetrical-measures-if-violatedthe-interests-of-the-russian-federation/ $>$ [In Russian].

54 'Fishermen wished to cross the "Shevarnadze-Baker line", RBK, 11 Oct. 2019

$<$ https://www.rbc.ru/business/11/10/2019/5d9f2d069a79473070a3af64>

[In Russian]. 
of provisional implementation of the Agreement currently would not mean that Russia acquires the same international legal positions in regard to the delimitation boundary in the Bering Sea as existed prior to the 1977 exchange of notes between the U.S. and the USSR and to the 1990 Agreement. Apart from that, the termination of provisional implementation would not take into account that the line of the 1867 Convention in the Bering Sea is more beneficial for the U.S., while being beneficial for both states in the Arctic Ocean." The withdrawal would underscore "the inconsistency of the Russian legal position" and would lead to "unpredictable implications, negative impact on the legal stability of the U.S.-Russia relations, including in the Arctic. In the present situation, it is feasible not to question the delimitation line in the Arctic Ocean and the Bering Sea set by the 1867 Convention and the 1990 Agreement". 55

For the purposes of this article it is important to note two aspects of this issue. First, the implementation of the Agreement provides Russia with the possibility of conflict-free delimitation of the continental shelf in the Arctic Ocean with the U.S. This line has been already drawn by the 1990 Agreement. Russia refers to it in its submission to the Commission on the Limits of the Continental Shelf, and Washington has expressed its approval in the response note. Although it may not necessarily complicate the review of the Russian submission by the CLCS, the withdrawal from the Agreement would force the issue of delimitation of the continental shelf of Russia and the U.S., perhaps on the conditions less favorable to Russia.

Second, against the backdrop of the Washington's narrative of rivalries with China and Russia in the Arctic, such Russian decision would create one more cause for conflict in the region, narrowing the space for constructive cooperation even further.

\footnotetext{
55 Vylegzhanin, A., et al., 'Proposals to the Roadmap of international legal framework for the U.S.-Russia cooperation in the Arctc: working paper., ed. I. Ivanov, Russian International Affairs Council, Moscow, Spetskniga, 2013, p. 20-21 [In Russian].
} 


\begin{abstract}
$* * *$
Despite the U.S. newfound rhetoric of competition with China and Russia in the Arctic, the likelihood of an arms race and military confrontation in the region in the foreseeable future is low. However, the high politics has been increasingly affecting the political climate, contributing to deeper and more permanent dividing lines, leading to narrowed space for Arctic cooperation.

In this environment, all Arctic states should exercise restraint and remain committed to responsible approaches both in the military and the political domains, as well as refrain from adopting decisions which may provoke other states' reactions.
\end{abstract}




\title{
7. MIDDLE EAST CONFLICTS: CORRELATION BETWEEN LOCAL AND REGIONAL FACTORS
}

\author{
Alexander SHUMILIN
}

\section{Evolution of the concept "the Middle East conflict"}

During the Cold War, the term "the Middle East conflict" was for the most part used for description of the Arab-Israeli confrontation, and more broadly, confrontation between Israel and Muslim countries. Tensions that had provoked at times hostilities between Arab countries ${ }^{1}$ were most often perceived as peripheral, and therefore, non-essential developments. Such a vision of the political landscape in the region was cultivated in the USSR and also met understanding in expert and political circles of the Western countries. This was due to the fact that the Arab-Israeli confrontation had been the main source of tension in the Middle East region which was viewed at the same time as a zone of fierce and constantly growing military and political rivalry between the Soviet Union and the United States (in contrast to the indeed "frozen" confrontation between the NATO and the Warsaw Pact countries in Europe). It was the Arab-Israeli line of tension that had had the greatest influence on the strategic planning and formulation of policies of Moscow and Washington in the Middle East as a whole.

The situation began to change gradually as a result of the overthrow of the Shah regime in Iran in 1979 and its replacement by the Islamic theocratic republic ruled by the Shia clergy. This has sharply increased the tension between the Islamic Republic of Iran and its Arab (Sunni) neighboring countries - the oil monarchies of the Persian Gulf led by Saudi Arabia, as well as Iraq. All these developments provoked

\footnotetext{
${ }^{1}$ Such as the Sand War between Algeria and Morocco (1963), the war between Egypt, Saudi Arabia and Yemen (1962-1967), clashes between Egypt and Libya (1977).
} 
an explosive leap in the centuries-old rivalry between Sunni and Shiites, which by then was in a latent state. During the Iran-Iraq war that broke out in 1980, Moscow and Washington supported de facto one side,-Saddam Hussein, who, however, had failed to defeat the Shia Ayatollah regime in Iran. After the Saddam's Iraq invasion of Kuwait in August 1990, the USSR and the United States began to coordinate their actions and policy concerning the conflicts in the region. In particular, both countries have condemned the Iraqi aggression at the UN Security Council meeting, which eventually led to the military operation of the international coalition to liberate Kuwait (operation Desert Storm, January-March 1991). This cooperation between Moscow and Washington was a vivid manifestation of the end of the Cold War.

The Iran-Iraq war of 1980-1988, which was fought against the background of a growing Sunni-Shiah confrontation, as well as Saddam Hussein's invasion of Kuwait in August 1990, have made it clear that there were other and even more dangerous sources of tension and destabilization in the region along with the Arab-Israeli conflict. This has logically expanded the concept of "the Middle East conflict", in such a way as to include both local inter-Arab clashes and intensification of Sunni-Shiah confrontation. A series of peace agreements between Israel and its neighbors, which were being signed over a few decades and sponsored by Russia and the U.S.A., including the Israeli-Palestinian (the Oslo Accords) and the IsraeliJordan agreements (a peace agreement with Egypt was signed in 1979), the withdrawal of Israeli troops from southern Lebanon and, finally, the 2000 Arab Peace Initiative, ${ }^{2}$ have, on the whole, fundamentally deprived the former meaning of the word "Arab-Israeli conflict": it has, in fact, been reduced to "Palestinian-Israeli conflict/standoff".

Iran's policy in the region, which was perceived by Sunni monarchies and Israel as expansionist, coupled with their fears over a controversial nuclear program of Tehran, steadily encouraged the monarchies to seek rapprochement with the Jewish state in the face

2 This initiative was proposed by Saudi Crown Prince Abdallah. It was endorsed by the 2002 Arab League Summit in Beirut and re-endorsed at the 2007 Riyadh Summit. 
of a "common threat". Nowadays the emphasis on the need to counter the "Iranian threat" has become a central element of the Donald Trump administration policy in the Middle East. According to its estimations, this policy focus can facilitate such a strategic task as establishment an open (rather than secret, as was the case in the 1990s and subsequent years) partnership between Sunni monarchies and Israel as the U.S. allies in the region. This process accelerated with the signing in Washington on September 15, 2020, of peace agreements between Israel and the two monarchies of the Persian Gulf, the UAE and Bahrain.

\section{From civil war to regional conflict}

The most dramatic and protracted internal armed conflict in the Middle East and North Africa region of recent decades has been the Algerian civil war (1991-2002). It has not, however, turned into a regional conflict, as the country's authorities were able to prevent direct intervention of other states. The crucial moment was that the armed groupings united in the name of radical Islam, went up against the Algerian authorities and the army, declared jihad against government and proclaimed a caliphate in the controlled territories. By doing this they distanced themselves from all local democraticallyoriented (secular, modernizing) parties and forces, although the latter had criticized the government many times before and after the civil war. In an attempt to expand their base of support, Islamists often used methods of terror against local people. But the effect was the opposite: the vast majority of people supported the actions of government and the army who remained cohesive in the face of terrorist threat and avoided splits within their ranks. These events in Algeria have often been interpreted in the world and in the region as "governmental fight against terrorism" rather than a "civil war". In our view, both definitions are legitimate, because, unlike the Islamic State (IS) in Syria and Iraq in 2014-2018, the Islamist militant units in Algeria were predominantly recruited of the Algerian citizens. 
When the Arab Spring began in 2011, mass anti-government protests and uprisings have spread across Syria, Libya, and Yemen, then turning into full-fledged civil wars. In their course various segments of population opposed governments under both secular (democratic) and religious slogans. In the case of Yemen, for example, tribal protests were actively exploited. The transition of peaceful protests into armed confrontation in all three countries was caused by the use of force (including military force) to suppress the unrest. A split in the authority structures and in the army as a result of the use of force against civilians has also become a common phenomenon. Under these circumstances, the opposing sides began to seek support from their ideological and political allies in the region, and this has led to transformation of the internal conflict into regional one.

In the case of Syria and Yemen, the internal situation there became a projection of the rivalry on the regional level between Shia Iran and Sunni monarchies, primarily Saudi Arabia (in Syria - between them and also Turkey). The latter, in fact, provide direct or indirect support to one of the conflicting parties without much risk of direct confrontation with each other, and this stimulates internal conflicts and strife in the countries mentioned above.

It is the asymmetry of the presence of Saudi Arabia and Iran in Syria and Yemen that allows them to avoid direct confrontation and fighting; in both cases one can see an open armed intervention of one key player and indirect (hidden) intervention of the other through its proxies. In Yemen, for example, the Saudi-led Arab coalition is fighting on the side of the internationally recognized President Hadi's government, while Iran is secretly shipping weapons and equipment to Hadi's foes, the Houthis (Shiites). In Syria, on the contrary, Quds Force units of the Iranian Islamic Revolutionary Guard Corps (IRGC), Iranian proxy formations and the Lebanese Shia militant group Hezbollah are fighting alongside President Bashar al-Assad, while Sunni monarchies and Turkey are providing arms and funding to Assad's adversaries. Each year from 2016 to 2019 Turkey had conducted military operations jointly with anti-Assad forces in northern and northeastern Syria in order to defeat not only Islamic State, but also groups affiliated with the Kurdish Workers' Party. In February 2020 Turkish armed forces 
and Syrian opposition units clashed directly with Assad's army in order to prevent its moving deep into the territory of Idlib province, for situation in which Ankara is responsible as a guarantor of the "deescalation zone" in Idlib (established in accordance with the terms of Astana agreements and the agreement between Vladimir Putin and Recep Tayyip Erdogan of September 2018).

Libya's case is quite different, because the Sunni-Shia confrontation has little impact on the conflict in the country. Here the problem is exclusively the one of the rivalry within the Sunni bloc, consisting in adherence of Saudi Arabia and other Arab monarchies' leaders on the one hand, and Turkey, on the other, to different doctrines within Sunni Islam. The Turkish elites are trying to assert the country's influence in the region through support of the Muslim Brotherhood movement, which represents one of forms of politicization (i.e. use of religion for political purposes) and, concurrently, limited modernization of Sunni Islam. The leadership of Sunni monarchies, for their part, condemns and criticizes Muslim Brotherhood, seeing in it a potential threat to the status quo in the region and, above all, to the authoritarian forms of government that they use. ${ }^{3}$ Monarchies prefer to "bet" on a less activist and almost depoliticized concept within Salafi Islam - "purism".

Taking into account the religious factor has provided the Erdogan's party associated with the Muslim Brotherhood an opportunity to pursue its broader interests in the Mediterranean region in partnership with the officially recognized Government of National Accord (GNA) of Fayez al-Sarraj in Lybia, where "moderate Islamists" represented by the "brothers" are part of a broad pro-governmental coalition. ${ }^{4}$ The Sarraj's main opponent, Field Marshal Khalifa Haftar, the commander of the Libyan National Army (LNA), is backed by Abu Dhabi and Riyadh. The Saudis are also seeking to gain influence

3 Tsaregorodtseva, I. A., 'Political and Legal Concepts of the Egyptian Muslim Brotherhood Ideologists', Scientific Notes of Kazan University. Series: Humanities, 2013, vol. 155, pp. 98-110 [in Russian].

4 'Al-Sarraj: Muslim Brotherhood is part of political scene', Libya Prospect, 7 Sept. $2016<$ https://libyaprospect.com/2016/09/

al-sarraj-muslim-brotherhood-is-part-of-political-scene/>. 
in Libya by relationships with local tribes professing Madkhalism, a specific Salafi version of Islam (it was named after a Saudi cleric and theologian Rabee al-Madkhali, who is close to the Saudi royal family). ${ }^{5}$

\section{Syria, Libya, Yemen: regional actors and strategies}

\section{Syrian conflict}

In 2019 in most parts of Syria the intensity of hostilities between local protagonists (the Assad's government and the Syrian opposition) has significantly decreased. In the autumn of that year, however, the situation in Idlib province began to deteriorate noticeably due to Syrian army's advance, supported by Russia and Iran, which resulted in deployment of Turkish troops there. Tensions with the possibility of unintended military clashes between Turkey and Russia had subsided after negotiations between Russian and Turkish presidents in Moscow on 5 March 2019. The agreement, however, did not change the political and strategic landscape in Syria that looks like following.

"Damascus Troika" (Syria, Iran, Russia). The Syrian government still lacks the political and military potential to maintain its role as an independent player. Its survival, as well as the expansion of areas under its formal control (about $60 \%$ of the country's territory), is ensured by the military efforts of Moscow and Tehran. Banking on their further support, Bashar al-Assad still declares that his government's strategic goal is to return the northwestern Idlib province (controlled by Turkey) and the northeastern oil-rich areas (controlled by Kurds, with American units in site). ${ }^{6}$ The goal of Iranian leadership that consists in establishment of a land corridor for weapons supplies to its factions in Syria and Lebanon (Hezbollah) and in creating an ability to threaten directly Israel from there should be regarded as a long-term

5 Oztas, T., 'ANALYSIS - Libya and the Salafi pawns in the game', Anadolu Agency, 9 Jan. 2020.

6 "Assad believes that Erdogan "used all his forces" against Syria at the behest of the Americans', TASS, 4 Mar. 2020. 
strategy. ${ }^{7}$ Iranian effort to intervene in confrontation between Shia and Sunni in Iraq and Lebanon, which escalated at the end of 2019, has demonstrated that Tehran continues to use the religious and ideological doctrines (Shia Islam) for geopolitical purposes; in particular, his aim is to create a "Shia Crescent" by strengthening ties between Shia communities in Arab countries and Iran. ${ }^{8}$

Unlike positions of Assad's government and Iranian leadership, which remain formally unchanged, there are some reasons to believe that Russia's approach to the situation in Syria might be partly corrected. This may occur due to the increased risk of confrontation between Russia and Turkey in northern Syria (in the event of reinforcement the offensive operations of the Assad's and Iranian forces in Idlib), the prospect of complicating political and strategic relations with Israel (in the event of expansion of Iran's military presence in Syria), as well as the possibility of further complication of relations between Russia and the EU (because of the worsening problem of refugees from Idlib), Russia and the United States (because of deterioration of relations between Washington and Tehran), and Russia and the Gulf monarchies (due to a crisis in the oil market). Formally, Moscow maintains its previous policy of promoting a political settlement through the search for compromise between the Assad government and opposition groups, i.e. the constitutional process. At the same time, it is in its interest, in the lack of prospects for a political settlement in Syria, to maintain the status quo in Idlib province and in the north of the country. But this will require, most likely, a greater pressure on Damascus and, in part, on Tehran.

Turkey. Many analysts tend to define the Turkish policy as pursued "outside a certain strategy." In any case, there were two periods of the Erdogan government's policy on the Syrian issue: the first (from 2011 to 2015), which was characterized by providing maximum support to almost all Syrian opposition groups, both secular and Islamist, with

\footnotetext{
7 'Iran's Strategy in Syria', The Cipher Brief's Network, 4 Mar. $2020<\mathrm{https}$ ://www. thecipherbrief.com/column_article/irans-strategy-in-syria $>$.

8 'Kasra Aarabi. Iran's Regional Influence Campaign Is Starting to Flop', Foreign Policy, 11 Dec. $2019<$ https://foreignpolicy.com/2019/12/11/

collapse-iranian-shiism-iraq-lebanon/>.
} 
the aim to oust the Assad's regime and combat the terrorist Islamic State; and the second (from 2015 till the present day), in which Turkey seeks to maintain its political role as a regional power, in particular through the Astana negotiation format, in which it acts together with Russia and Iran, and to gain control over Syria's northern territories (Idlib province and the border areas). In the second stage, Ankara is fulfilling its primary task to counteract the strengthening of groups affiliated with the Kurdish Workers' Party in areas near its border.

To that end, Ankara endeavors to establish an expanded security zone along the Syrian-Turkish border, relying on Syrian opposition groups, which were partially transformed into the Syrian National Army, almost entirely controlled by Turkey. Ankara will also maintain its current position on Idlib province in the near future to ensure the return of hundreds of thousands of Syrian refugees who fled to Turkey during Syrian army's offensive in late 2019 and early 2020. In this regard, Ankara's strategy and actions are being supported by the United States and the European Union.

Saudi Arabia and the UAE. These two monarchies had supported the Syrian opposition with varying intensity from 2011 to 2018. From the end of 2018, however, the UAE step by step started to establish contacts with Assad's government, opening its embassy in Damascus in December 2018. Since autumn 2019 and against the background of the Turkish invasion in Syria, Saudi Arabia has undertaken steps in the same direction, preferring to do it, however, in a more confidential way than Abu Dhabi. ${ }^{9}$ The reason for such corrections of the political course of the Gulf monarchies was that the general vector of the situation in the region has changed in favor of Damascus against the background of military victories of Syrian government and its allies. All these developments were interpreted in Riyadh and Abu Dhabi primarily from religious and ideological point of view: the success of Damascus shaped a new balance of forces in and around Syria, it meant simultaneously a sharp strengthening of both Iranian and Turkish

9 'Report: Saudi Arabia paves way to restore ties with Syria', The Middle East Monitor, 22 Jan. $2020<$ https://www.middleeastmonitor.com/20200122-reportsaudi-arabia-paves-way-to-restore-ties-with-syria/>. 
positions in this Arab country, while Iran is traditionally perceived by the Gulf monarchies as a political and ideological "adversary", and Turkey as a "rival." As a result, the diplomatic efforts of the monarchies in recent years are being conducted under the slogans of "returning Syria to the Arab family" and getting rid of "all kinds of Islamism" (both Shia and Sunni). It is noteworthy, that the leaders of Saudi Arabia and the UAE, taking advantage of the fight against the Coronavirus pandemic, have significantly normalized their relations with Damascus on the pretext of providing humanitarian assistance. ${ }^{10}$

Egypt. The Egyptian military headed by Field Marshal Abdel Fattah al-Sisi, who came to power in July 2013 after a military coup against President Mohamed Morsi, from the outset expressed sympathy to the Syrian President Bashar Assad for his efforts to combat Islamism, in particular Muslim Brotherhood group. Egypt was one of the leading voices calling the members of the Arab League to return Syria to this organization (it was expelled in November 2011). Since the end of 2019, against the background and as a result of Turkey's military operation "Peace Spring" in the northern Syria, the Egyptian leadership has increased political support for the Assad's government. It may be said, in this regard, that a political bloc of the three most influential Arab states (Saudi Arabia, the UAE, and Egypt) is being formed, while the regional policies of these states are becoming more and more antiTurkish (as an opposition to "Neo-Ottomanism" based on the doctrine of the Muslim Brotherhood in the religious aspect). ${ }^{11}$ Egypt's increased role in it is largely attributed to the aforementioned reversal in policies of Saudi Arabia and the UAE, who provide substantial financial assistance to Cairo. The joint views of countries within this Arab bloc

\footnotetext{
10 "Humanitarian solidarity at difficult time is replacing all other problems," said Abu Dhabi Crown Prince Mohammed bin Zayed. See: Almustafa, H., Fenton-

Harvey, J., 'Why the UAE aims to leverage Assad', Middle East Eye, 10 Apr. 2020 $<$ https://www.middleeasteye.net/opinion/how-uae-aimsleverage-assad-amid-coronavirus-crisis $>$.

${ }_{11}$ Cafiero, G., 'Egypt's Growing Support for Bashar al-Assad', Inside Arabia, 25 Nov. $2019<$ https://insidearabia.com/egypts-growing-support-for-basharal-assad/>.
} 
are motivated by their opposition to military and political alliance of Turkey and Qatar, who tend to share many Muslim Brotherhood's ideas. $^{12}$

The opposing positions of these two groups of Sunni States can more vividly be seen in conflict in Libya.

\section{Conflict in Libya}

Almost all the same regional actors as in Syria (plus Russia, minus Iran) are being involved in the conflict in Libya, with almost the same motivation (Libya's strategic importance in the Mediterranean, oil reserves, transportation routes, etc.). The causes of the conflict within Libya lie in the armed confrontation between the UN-recognized Government of National Accord (GNA), led by Fayez al-Sarraj, which is based in Tripoli, and the so-called Libyan National Army (LNA) under the command of Field Marshal Khalifa Haftar (with headquarters in Tobruk). Only Turkey is directly involved in the conflict in favor of one of the parties - namely, the GNA; other states and actors claim their formal neutrality. In reality the model of support of Libyan protagonists by regional states and Russia ${ }^{13}$ looks as follows: Turkey and Qatar stay on the side of the GNA; Egypt, the UAE, Saudi Arabia, and Russia - on the side of Haftar. All actors directly or indirectly involved in the conflict are motivated by geostrategic interests, which have strong religious connotations in the countries of the region (unlike Russia). They consist in support of the Muslim Brotherhood's

\footnotetext{
12 Başkan, B., Pala, Ö., 'Making Sense of Turkey’s Reaction to the Qatar Crisis', The International Spectator, 4 May 2020, DOI: 10.1080/03932729.2020.1739846 $<$ https://www.tandfonline.com/doi/full/10.1080/03932729.2020.1739846>.

13 'UN confirms Russian mercenaries are fighting in Libya: diplomats', $A F P$, 7 May $2020<$ https://www.afp.com/en/news/15/un-confirms-russian-mercenariesare-fighting-libya-diplomats-doc-1r18di4>. Moscow does not deny the presence of Russian "volunteers" in Libya and their participation in conflict on the side of Haftar, emphasizing that they neither act there in the interests of the Russian state nor are financed from the Russian budget. For more details, see: "Putin answered a question about Russian mercenaries in Libya", RBC, 11 Jan. 2020.
} 
followers,${ }^{14}$ who are part of the GNA structures, by Turkey and Qatar, and, accordingly, in non-recognition of representatives of this political and religious segment by Khalifa Haftar and his supporters. ${ }^{15}$

After a period of local and sporadic fighting between the supporters of the GNA and the LNA in 2017-2018, Haftar launched a strategic offensive in April 2019 to seize the capital city of Tripoli, but it was stopped at first by the armed groups backing the GNA and then by Turkey army units being deployed in January 2020 on the outskirts of Tripoli. International efforts to help the parties of the Libyan conflict to reach a compromise (a conference on reconciliation was held in January 2020 in Berlin, before that France and Italy had made similar reconciliation efforts in 2018) appear to have failed. In spring 2020 Haftar resumed fighting in the suburbs of Tripoli, and on 30 April he proclaimed himself as a country's ruler "by popular mandate". ${ }^{16}$

The LNA commander could take such a step only in condition of continued military and financial assistance provided by the regional partners mentioned above. Thus, the conflict in Libya is markedly escalating.

\section{War in Yemen}

The reasons for the civil war that has begun in 2015 between the Houthis (Ansar Allah movement) and the central authorities in Yemen were more of a religious than socio-economic nature. Political reforms in Yemen in the midst of the Arab Spring (2012-2014) have significantly exacerbated traditionally peaceful past relations between the Houthis, who adhere to the Zaidi sect of Shia Islam, and the country's Sunni majority. At that time, the Sunni parties - in particular, Al-Islah affiliated with the Muslim Brotherhood, and parties promoting

\footnotetext{
14 'Turkey's Attempt to Tighten the Muslim Brotherhood's Grip on Libya', European Eye on Radicalization, 10 Jan. $2020<$ https://eeradicalization.com/ turkeys-attempt-to-tighten-the-muslim-brotherhoods-grip-on-libya/>.

15 Allahoum, R., 'Libya's war: Who is supporting whom', Al Jazeera, 9 Jan. 2020.

16 Didili, Z., 'Haftar declares himself ruler of Libya, LNA to take formal control', New Europe, 30 Apr. $2020<$ https://www.neweurope.eu/article/ haftar-declares-himself-ruler-of-libya-lna-to-take-formal-control/>.
} 
the Salafi concept of Islam, close to its version which is widespread and strongly supported in Saudi Arabia - began to strengthen influence in the country. The Houthi military rebellion was a kind of response to the "Sunni expansion" into areas traditionally inhabited by the Houthi tribes. From the beginning of their protests, the Houthis have received support from Iran. ${ }^{17}$ As a result of the insurgency, the Houthis took control of the country's capital Sana'a in January 2015, and seized the presidential palace, after which the head of the state Abdrabbuh Mansur Hadi was forced to flee. ${ }^{18}$ To restore a legitimate authority in Yemen and prevent further Iranian interference on the Houthi side, Saudi Arabia and the UAE have launched the "Arab coalition" that has been conducting military operations in Yemen since March 2015. ${ }^{19}$

By summer 2019, however, a notable discrepancy had emerged among the leading members of the "Arab coalition"-Saudi Arabia and the UAE. It was caused primarily by political divisions in the inner circle of Yemeni President Hadi: a group of southerners announced plans of separation of southern provinces from the northern part of the country and restoration of South Yemen in nearly the same form as it had been before unification with North Yemen in 1990. The UAE leadership has in general supported the separatist's plans and actions, while Riyadh has condemned them. Tensions sharply increased in summer and autumn 2019, when supporters of the southern separatists began to oust the appointees of the Saudi authorities from

\footnotetext{
17 'Iran admits supporting Houthis in Yemen for the first time', The Middle East Monitor, 3 Oct. $2019<$ https://www.middleeastmonitor.com/20191003-iran-admitssupporting-houthis-in-yemen-for-the-first-time/>.

18 Bayoumy, Y., Ghobari, M., 'Yemen president quits, throwing country deeper into chaos', Reuters, 22 Jan. $2015<$ https://www.reuters.com/article/us-yemensecurity-houthis/yemen-president-quits-throwing-country-deeper-into-chaosidUSKBN0KV0HT20150122>.

19 Kuwait, Bahrain, Egypt, Jordan, Morocco, Qatar, and Pakistan have also participated in the "Arab coalition". Military operations are being conducted predominantly by Saudi Arabia and the United Arab Emirates, while other countries are making different contributions to relevant support missions. See: Gambrell, J., 'Here are the members of the Saudi-led coalition in Yemen and what they're contributing', Associated Press, 30 Mar. $2015<$ https://www.businessinsider. $\mathrm{com} / \mathrm{members}$-of-saudi-led-coalition-in-yemen-their-contributions-2015-3>.
} 
the administrative bodies in the south. Washington was concerned about the divergence between Riyadh and Abu Dhabi, which could have far-reaching negative effect not only on the fighting in Yemen but also on the confrontation of the monarchies with Iran and the terrorist group "Al-Qaeda in the Arabian Peninsula". ${ }^{20}$ Washington's concerns were fuelled by statements and specific actions of the United Arab Emirates such as partial withdrawal of the UAE forces from Yemen and declaring the end the country's rivalry with the Houthis.

There is reason to believe that the pivot in Abu Dhabi's strategy was caused by a series of explosions on oil tankers in the UAE's ports and waters in spring and summer 2019, which were assessed by the country's leadership as possible Iranian acts of sabotage. ${ }^{21}$ As there was no forceful response of the U.S. and Saudi Arabia to deter Iran, the UAE leadership, presumably, experienced vulnerability of their country to possible retaliatory strikes from the Shia power. Later on ballistic missile and drone attacks against Saudi oil facilities remained without any reaction, too. ${ }^{22}$ In this context, Abu Dhabi's actions were aimed at reducing the level of confrontation directly with Iran. The cessation of direct fighting between the Emirati forces and the Houthis in Yemen, the end of indirect confrontation with Iran there, as well as steps towards normalization of relations with the Assad's regime in Syria have become a part of a new UAE regional strategy, the second most important constant of which was countering the spread of the Muslim Brotherhood's influence.

The new strategy of the United Arab Emirates in Yemen differs markedly from the recent joint approach of Abu Dhabi and Riyadh, aimed at returning of the legitimate Hadi government to Sana'a and preservation of the territorial integrity of Yemen. Now the UAE

\footnotetext{
20 Wintour, P., "Saudi Arabia and UAE attempt to paper over Yemen cracks", The Guardian, 9 Sep. 2019.

21 'UAE tanker attacks blamed on "state actor", BBC News, 7 Jun. 2019.

22 Kirkpatrick, D., Hubbard, B., 'Attack on Saudi Oil Facilities Tests

U. S. Guarantee to Defend Gulf’, The New York Times, 19 Sept. 2019.
} 
political line seems to be opposite to these goals. ${ }^{23}$ The split in Yemeni government circles (the separation of a group of southern separatists) and the ensuing divergence among "Arab coalition" leaders had forced the latter to take advantage of the Coronavirus pandemic to declare a two-week ceasefire on April 8, which was unilaterally extended for a month, even though the Houthis disapproved it. ${ }^{24}$ The intensity of fighting has decreased during this period, though clashes continued.

If the strategies of regional actors toward Yemen remain as outlined, the country will be doomed to split into two relatively autonomous (state) entities, i.e. the Arab Sunni part in the south and the Arab Shia - in the north, with reproducing of conflict between them. The emergence of the Shia state in such a case would become a historically significant fact and would mark a significant success of Iran's policy, as there has been no other Shia state, except Iran, in the Middle East history.

\section{Geopolitics in the context of religion}

In all three conflicts - Syrian, Libyan, and Yemeni-the role of regional actors is extremely high. It is they who, through direct or indirect intervention, predetermine the transformation of an internal conflict into a regional one, even changing its nature and structure in some cases. This was particularly evident in Syria and Yemen. In Syria the government's fierce struggle with opposition has grown into its confrontation with Turkey, the Kurdish units ${ }^{25}$ backed by Turkey and international coalition, and the remnants of the Syrian Free Army. In Yemen, the "Arab coalition" countries (Saudi Arabia, in the end) have become the major force that opposed the Houthis. In Libya it is likely

\footnotetext{
${ }^{23}$ Jalal, I. 'Five Years on, has the Arab coalition achieved its objectives in Yemen?', Middle East Institute, 2 Apr. $2020<$ https://www.mei.edu/publications/ five-years-has-arab-coalition-achieved-its-objectives-yemen>.

24 'Saudi-led coalition extends unilateral Yemen ceasefire by a month', Al Jazeera, 24 Apr. 2020.

${ }^{25}$ Such as the People's Protection Units (YPG), the Syrian Democratic Forces (SDF) and the Women's Protection Units (YPJ).
} 
that Turkey's armed forces and militias, being trained by Ankara and transferred there from the northern Syria, will be the core of forces counteracting the Haftar army.

In other words, internal conflicts that started as civil wars between the two main opponents are being transformed into situations, where foreign armed forces confront now one of the two protagonists. Thus, in Syria the opposition is fighting with Russian and Iranian forces, in Yemen the Houthis are fighting with Saudi Arabia and the coalition, and in Libya Haftar's LNA is confronting pro-Turkish forces. Thus, initially internal conflicts are acquiring the characteristics of regional ones. At its more advanced stage, the remaining protagonists may gain "protection" from other regional actor or actors; in Syria, for example, the Assad's opposition is now under protection of Turkey. As a result, internal conflicts (civil wars) in Arab countries are gradually escalating into conflicts between states of the region and, more broadly, conflicts involving non-regional states (as in the case of Syria).

At the same time, it can be said, that the main strategic paradigm of regional actors - political-religious, or confessional - is being evolved, too. With the remaining dominant clout of the main sectoral "rift" in the region - between Sunni and Shia Muslims (at the state level, between the most Arab countries and Iran) - the "rift" within the Sunni branch of Islam is also noticeably growing. The major watershed in this case lies in the attitude of Sunni elites to the Muslim Brotherhood religious-political association (Islamist movement). The basic doctrine of the Muslim Brotherhood is aimed at building of a state based on such fundamental norms of Islam as "uniting of state and religion" and "equality of all believers before Allah", which mean the eligibility of everyone to participate in governance, control of government by communities, and introduction of Sharia norms. In the current context this presupposes the participation of Muslim organizations in political and public life of the country of residence ("soft Islamism" that can 
coexist with other faith communities). Therefore, the rulers, who are not controlled by the community, are "disgusting for Allah", according to the Muslim Brotherhood's doctrine. ${ }^{26}$

This worldview fully contradicts to the norms and traditions of Arab monarchies, in which power actually passes from one member of a ruling family to another by inheritance, while the religion is formally separated from the state and is most often tightly controlled by the rulers. In a Muslim clergy the monarchs prefer to see guardians of religious norms and traditions, moral preachers, but not people who claim to power "under the slogans" of Islam. That is why they rely on formally "depoliticized" ("purist") interpretations of the Quran 27 (like in Salafism and Wahhabism) that actually support authoritarian power. At the same time, they are trying to increase their "Islamic legitimacy." 28 The Arab Spring has opened up opportunities for engagement of supporters of the Muslim Brotherhood in political life in Tunisia, Libya, Egypt, Syria, and Yemen. The Gulf monarchies, led by Saudi Arabia, have mobilized all resources to hinder the electoral success of the Muslim Brotherhood in all these countries (for example, in Egypt, the Islamist President Mohamed Morsi was ousted in July 2013). Now they see their priority as preventing dominance in civil wars

\footnotetext{
${ }^{26}$ In this regard the following doctrinal statements by Hassan al-Banna, one of the founders of the Muslim Brotherhood movement, may be cited: the goal of the community leader is limited to "overseeing the implementation of Sharia law"; "failure to respect the public interest (al-masalih al-amma) and the principles of Sharia could lead to punishment of a political leader"; "the building of an Islamic state requires the obligatory reunification of politics with religion"; "active resistance to unjust power is the higher duty of those who adhere to the path of Allah." Cit. ex.: Tsaregorodtseva I. A. 'Political and Legal Concepts of the Egyptian Muslim Brotherhood Ideologists', Scientific Notes of Kazan University. Series: Humanities, 2013, vol. 155, pp. 98-110 [in Russian].

27 Gauvain, R., Salafi Ritual Purity: In the Presence of God, New York, Routledge, 2013, p. 41.

28 Since 1986, the Saudi monarch has held the title "Custodian of the Two Holy Mosques", as the rulers of the Arab Caliphate called themselves, introduced by King Fahd instead of "His Majesty."
} 
of pro-Iranian forces (such as the Alawites in Syria and the Houthis in Yemen) and groupings affiliated with the Muslim Brotherhood (in Libya and Yemen).

Referring to the role of religious doctrine in foreign policy of Iran, on the one hand, and Saudi Arabia, on the other, two important points should be stressed. Firstly, the Islamic Revolution was proclaimed in Tehran as a model for all Muslim countries, and its export-as official policy of Iranian authorities; therefore, the Sunni monarchies are acting actually in the regime of "defense" against Shia expansion. Secondly, as for approaches to nation-building (building the "Islamic Republic"), there are many more similarities between the Iranian doctrine and the religious and political concept of the Muslim Brotherhood than differences. This explains, among other things, the absence of deep antagonism between the political and religious elites of such states as Turkey and Qatar, on the one hand, and Iran, on the other, and their ability to communicate. Cooperation of Palestinian group Hamas in Gaza, associated with the Muslim Brotherhood, with Qatar, Iran and Turkey can be considered as a striking example in this regard.

Geopolitical calculations in regional strategies of Riyadh, Cairo, Ankara, and Tehran are closely linked to sectarian ones. The main geopolitical challenges for the Arabian monarchies (first of all, for Saudi Arabia and the UAE) still consist in preserving the entire Arabic-speaking space in its present state, and preventing the expansion of the territorial segments controlled by Iran in it (as is now the case in Syria, Yemen and partly in Iraq, and as previously was in Lebanon, where Hezbollah was "legalized"). In recent months, however, the task of countering the growing influence of Turkey in the Arab space - in Syria, Iraq, and Libya - has become equally important. The Gulf monarchies and Egypt have demonstrated the most active confrontation with Turkey on the Libyan foothold, providing all possible assistance to the Haftar army. Opposition to Turkey's actions, together with the struggle against the Muslim Brotherhood, seems to become as meaningful problem for them as confrontation with Iran. For example, Riyadh has intensified its activities in this direction in 
response to deployment of Turkish troops in Tripoli in early $2020^{29}$ just as has been done against the backdrop of the Turkish invasion of Syria in the fall 2019 - winter 2020, when normalization of Saudi relations with the Assad's government was speeded up.

The geopolitical guidelines of Turkey, Qatar and Iran can be formulated within one model: expanding influence in Arab countries through a bet on the Muslim Brotherhood (policy of Ankara and Doha) and on local Shia communities (Iran's policy). In fact, these three countries attempt to rely on the relevant religious communities in some Arab countries, the reinforcement of which is fraught with political division there, that could lead to a territorial division. That's what is happening today in Syria and Yemen; Libya, in its turn, is nearing the stage of a territorial split. As for Iraq, the Iranian leadership, apparently, expects to bring about there the recognition and formalization of a new reality, namely, the actual predominance of the Shia population over the Sunnis within the existing state. This is what the Arab monarchies are trying to prevent. Whether a confessional model of power structure, similar to that has been in Lebanon since the 1940s, would work well in Iraq, remains to be seen (in Lebanon Shias are a minority, while in Iraq they constitute a majority). This means that the goal of Iran's longstanding interference in Iraq's internal affairs must have consisted in attempts to establish a preferential status for Shias in that country.

In a whole, the fragmentation of the Middle East political landscape is increasing as a result of growing rivalry and confrontation between the bearers of the three predominant religious identities - representatives of Sunni branch of Islam (Salafis and the Muslim Brotherhood) and the Shia branch of the religion. The main regional actors elaborate their strategies with this factor in mind. These conflicting strategies, in turn, do cause escalation of internal conflicts in some countries of the Middle East region.

\footnotetext{
${ }^{29}$ Ramani, S., 'Saudi Arabia Steps up Role in Libya', Al-Monitor, 24 Feb. 2020.
} 


\title{
8. THE INDO-PAKISTANI MUTUAL DETERRENCE: STRATEGIC CULTURE AND NUCLEAR STRATEGY
}

\author{
Konstantin BOGDANOV and Alexey KUPRIYANOV \\ India and Pakistan possess the diverse and ever-growing arsenals of \\ nuclear weapons. ${ }^{1}$ However, these countries also have fundamentally \\ different strategic cultures. This is due both to the difference in military \\ and economic power, as well as to the history of relations between \\ countries. India's nuclear planning is based on a combination of factors: \\ the desire to deter Pakistan from using nuclear weapons, the guarantee \\ of non-aggression from China, and a demonstration of its status as a \\ responsible great power. Pakistan's nuclear planning exclusively targets \\ India and seeks to compensate for the imbalance in the capabilities of \\ conventional forces.
}

\section{India: nuclear project development}

Work on nuclear weapons in India began as soon as the country gained independence. They were initiated by Homi Bhabha, a leading Indian physicist. At the same time, the discussion in the political community of India began immediately. "The Hawks" have pointed out that all great powers, including China, are actively seeking to obtain and expand their nuclear arsenals, viewing nuclear deterrence as a necessary condition of security. Their opponents opposed the project for both economic and moral reasons, arguing that the presence of nuclear weapons would only worsen the regional security and undermine India's position as a peaceloving power on the world stage. The outcome of these discussions was consensus: India should not sign the Treaty on the Non-Proliferation of Nuclear Weapons until the nuclear powers submit a credible and comprehensive nuclear disarmament plan.

${ }^{1}$ For details on the nuclear arsenals of India and Pakistan, see: chapter 6, sections VI and VII, in the SIPRI Yearbook 2019. 
At the same time, theoretical work on the nuclear program continued. Although a number of Indian sources indicate that India had the capability to develop nuclear weapons as early as 1956, practical work began in November 1964 when Prime Minister Lal Bahadur Shastri ordered work on a project to conduct an underground nuclear explosion, ostensibly for peaceful purposes (Subterranean Nuclear Explosion for Peaceful Purposes, SNEPP). The start of that project seems to have been due to the collapse of Jawaharlal Nehru's IndiaChina rapprochement policy, India's defeat in the 1962 border war against China and the need for a fundamental review of the very foundations of foreign policy.

Over the next decade, Indian scientists created an explosive device that was tested on 18 May 1974 by order of Prime Minister Indira Gandhi. Despite the fact that India immediately declared the peaceful nature of testing, foreign analysts concluded that India had a military nuclear program. Contrary to expectations, however, India limited itself to a single test, did not conduct new explosions and did not declare that it had nuclear weapons.

In 1986-1987, India conducted the Brasstacks military exercise in Rajasthan, which was seen by Pakistan as preparation for the invasion. This led to another crisis between the two powers, during which the Pakistani leadership informed Indian diplomats that it is ready to use nuclear weapons in such cases. ${ }^{2}$ India was aware of Pakistan's military nuclear program and took the possible threat very seriously. This led to the start of work on a military nuclear device by order of Prime Minister Rajiv Gandhi, which was carried out in parallel with the promotion of India's nuclear disarmament initiatives in the international arena.

In the early 1990s, after the collapse of the USSR and a fundamental change in the world situation, a political consensus emerged in India on the need to develop nuclear weapons as soon as

2 Although Pakistan detonated its first nuclear device only in 1998, according to a combined assessment made by experts and the U.S. intelligence community, augmented by the ex post facto testimony of Abdul Qadeer Khan, a key expert in the country's nuclear program, Pakistan was able to assemble such a device as early as 1984, a fact undoubtedly considered by India at that time. 
possible. India refused to sign the Comprehensive Nuclear-Test-Ban Treaty (CTBT) considering it as an attempt to limit its capabilities. In 1995, Narasimha Rao's government approved a nuclear testing program, which, however, was postponed under U.S. pressure. Nuclear tests were conducted only on 11 and 13 May 1998, after the opposition Bharatiya Janata Party (BJP) came to power, and became a surprise to foreign observers. India declared itself a nuclear weapon state and also announced the adoption of a doctrinal provision prohibiting its first use ("No-First-Use" policy).

The government of Atal Bihari Vajpayee, which authorized the conducting of tests, was attacked by the opposition. He was accused of letting India come under the fire of critics instead of continuing to develop nuclear weapons in secret, waiting for a better time. This episode clearly demonstrates the total unity of opinion within Indian elites on the possession of nuclear weapons. As one Indian observer noted immediately after the tests, "No government in India will go against the consensus in favour of creation of an adequate nuclear deterrent." 3

Almost immediately, a series of nuclear tests in Pakistan followed. As a result, the 1999 Kargil crisis was the first armed conflict between the two nuclear states in world history.

\section{Key Imperatives}

India's strategic culture on nuclear policy is based on the three whales, namely nuclear deterrence of Pakistan, nuclear deterrence of China and a demonstration of a responsible great power's stance.

Nuclear deterrence of Pakistan. At present, Pakistan is the most likely adversary of India, possessing nuclear weapons and considering these weapons as the main means of defense in the conventional war with India. The first task of India's nuclear forces under these

\footnotetext{
3 Nalapat, M. D., “Eagle's Eye View: Isolating India to Help China”, The Times of India, 25 June 1998.
} 
circumstances is to prevent Pakistan from using nuclear weapons to strike back at Indian armed forces and civilian targets through the threat of a massive retaliatory strike.

Nuclear deterrence of China. Since 1962, China has been regarded in India as the most dangerous adversary. Unlike Pakistan, which is inferior to India in terms of quality and quantity of conventional weapons, China obviously surpasses it; however, the possibility for the Chinese to conduct large-scale operations south of the Himalayas is significantly hampered for geographical reasons. From this point of view, nuclear weapons are seen as the deterrent means that, under the threat of unacceptable damage, should not allow the Chinese to use their nuclear forces in the event of the outbreak of the large-scale IndoPakistani conflict. All in all, this part of nuclear strategy is the least covered in Indian theoretical studies.

Finally, India has positioned itself as a responsible great power, seeing the possession of nuclear weapons as a necessary condition for admission to the "club" of great powers. Equally important, in the minds of Indian politicians, is the awareness of the responsibility of the nuclear-weapon states and the contrast between India as a country that understands this responsibility and its neighboring Pakistan, which is seen by the Indians as an adventurist state and a "nuclear supermarket" that spreads nuclear technologies.

An integral part of this discourse is unconditional control over nuclear weapons by civilian, democratically elected authorities: India's nuclear doctrine states that the decision to launch a nuclear strike can only be made by the Prime Minister or his "designated successor." In the opinion of Indian elites, the end result of this approach should be India's formal admission to the "club" of nuclear powers.

\section{Possible doctrinal evolution}

Almost immediately after the promulgation of the draft nuclear doctrine, the Indian leadership provoked rumours about its possible revision. For example, in 2000, during the latest escalation of relations with Pakistan, Prime Minister Vajpayee stated, "If they think we would 
wait for them to drop a bomb and face destruction, they are mistaken." 4 This statement was interpreted by foreign experts as a willingness to launch a pre-emptive nuclear strike or launch-on-warning attack. Indian experts, in turn, pointed out that the Prime Minister did not say that India would use specifically nuclear weapons.

In 2003, immediately after agreeing on final version of the nuclear doctrine, the Indian Foreign Ministry issued a press release reiterating India's commitment to a "No-First-Use" policy, but stating that nuclear weapons could be used in response to an attack using biological or chemical weapons, as well as in the event of a nuclear attack "on Indian forces anywhere." ${ }^{5}$ While the end of the statement affirmed the commitment to the "No-First-Use" policy and pointed out that India's doctrine had not changed from the draft, such wording implied that India could respond with a nuclear strike against Pakistan if it used tactical nuclear weapons (TNWs) against Indian armed forces that would entered its territory during conventional conflict.

In 2010, National Security Adviser Shivshankar Menon created a sensation by pointing out that India may in the future move away from a "No-First-Use" strategy towards "No-First-Use against nonnuclear-weapon states" and that this doctrine would reflect "India's strategic culture, with its emphasis on minimal deterrence." " In April 2013, Shyam Saran, a member of the National Security Advisory

4 The Hindu, 'Talks only on return of PoK, says Vajpayee', 7 Feb. 2000.

5 The Cabinet Committee on Security Reviews Operationalization of India's Nuclear Doctrine $<$ https://mea.gov.in/press-releases.htm?dtl/20131/The_Cabinet Committee_on_Security_Reviews_perationalization_of_Indias_Nuclear_ Doctrine+Report+of+National+Security+Advisory+Board+on+Indian+Nuclear+ Doctrine $>$.

6 Speech by NSA Shri Shivshankar Menon at NDC on 'The Role of Force in Strategic Affairs', <https://www.mea.gov.in/Speeches-Statements.htm?dtl/798/ Speech + by + NSA + Shri + Shivshankar + Menon + at + NDC + on + The + Role + of + Force + in + Strategic + Affairs $>$. 
Board known for his criticism of a possible nuclear doctrine revision, said India will respond with a full-scale strike, regardless of whether it would an attack with tactical or strategic nuclear weapon. ${ }^{7}$

The BJP party's return to power in 2014 raised fears of possible doctrinal changes, as the party's election program contained a promise to "revise India's nuclear doctrine," 8 in particular, according to some sources, a "No-First-Use" policy. ${ }^{9}$ This did not happen; however, senior officials have repeatedly hinted at the possibility of such a review.

For example, in 2016, Defense Minister Manohar Parrikar said that India may not need a "No-First-Use" doctrine, as it is a "responsible nuclear power" and sees no need to encumber itself additionally. ${ }^{10}$ Later, when the statement was widely discussed by the media, Parrikar hurried to clarify that this was his personal opinion. In the same year, former National Security Adviser Shivshankar Menon said that "India's nuclear doctrine is much more flexible than one might think." Finally, in 2019, Defense Minister Rajnath Singh announced that in the future, India "due to changed circumstances" may abandon the "No-First-Use" doctrine. ${ }^{11}$

Nevertheless, India continues to declare its commitment to the doctrine and has no official intention of abandoning it in the foreseeable future. In doing so, the published part of the doctrine implies a massive nuclear retaliatory strike in response to the use of nuclear weapons against India or Indian troops.

\footnotetext{
7 Ahmed, A., India, Nuclear Weapons and 'Massive Retaliation': The Impossibility of Limitation?, IPCS Debate, 8 Oct. $2013<$ http://www.ipcs.org/comm_select. php?articleNo=4135>; Bagchi, I., 'Even a midget nuke strike will lead to massive retaliation, India warns Pak', The Economic Times, 30 Apr. 2013.

${ }^{8}$ Ek Bharat-Shreshtha Bharat, New Delhi, Bharatiya Janata Party, 2014, <http:// www.bjp.org/images/pdf_2014/full_manifesto_english_07.04.2014.pdf>.

9 Miglani, S., Chalmers, J., 'BJP Puts 'No First Use' Nuclear Policy in Doubt', Reuters India, 7 Apr. 2014.

10 The Hindu, 'Why bind ourselves to "no first use policy", says Parrikar on India's nuke doctrine', 10 Nov. 2016.

11 The Hindu, "No First Use" Nuclear Policy Depends on Circumstances: Rajnath Singh', 16 Aug. 2019.
} 
The fact that Pakistan possesses nuclear weapons limits India's ability to launch retaliatory strikes on Pakistani territory. A strategic stalemate has emerged, which India is trying to solve by focusing on the development of BMD combined with precision-guided weapons to prevent a possible Pakistani nuclear strike, which is similar to the American "left-of-launch" concept for theater missile defense. The point is that since Indian BMD is unable to intercept all missiles that Pakistan can launch in a massive nuclear strike, one of the promising options is to neutralize the bulk of Pakistani nuclear capability through pre-emptive strikes by non-nuclear precision-guided weapons, followed by the interception of the remaining incoming missiles, which Indian BMD, as the military implies, would cope with. Moreover, the Indian leadership does not rule out the possibility that Pakistani nuclear weapons could fall into the hands of terrorists, forcing them to continue working in this direction and politically justifying them.

India now possesses all the components of the nuclear triad and tries to present itself on the international arena as a responsible power by imposing a unilateral moratorium on nuclear testing, supporting negotiations on a possible Fissile Material Cut-off Treaty (FMCT) and regularly launching nuclear risk reduction initiatives at the UN. At the same time, India has no intention of renouncing nuclear weapons until the world has completely renounced them. The question of the further evolution of nuclear doctrine towards the renunciation of the "No-First-Use" principle remains open, although there is an opinion in Indian military circles and related parts of political elites that this principle has outlived its utility.

Reflecting these discussions on the military-technical level, among other things, is the issue of the equipment of Indian missiles with MIRVs. Caused mainly by the problems of adjusting the militarystrategic balance in the nuclear area with China, it also directly affects Indo-Pakistani nuclear deterrence, being a potential factor in accelerating the regional nuclear arms race.

The Agni missile family, which was introduced by the Indian Armed Forces from 2004 till 2007, began with models with a combat range of $700 \mathrm{~km}$ (they were primarily aimed at deterring Pakistan), and 
the latest systems are capable of hitting targets at ranges up to 5,000 km. According to some estimates, the next missile should become a fullfledged intercontinental delivery vehicle.

The focus on medium- and intermediate-range missiles, with further steady increases in their range, is not about problem of Pakistan, but deterrence of China. However, under the current circumstances, such weapons are also suitable for deterring Pakistan with the threat of retaliatory strikes against its strategic targets deep in the territory or even cities.

The sea-based leg of the nuclear triad has developed in a similar way. At the moment, Indian K-15 SLBMs deployed on Arihantclass submarines have a range of only $700 \mathrm{~km}$, but K-4 SLBMs with a range of up to $3,500 \mathrm{~km}$ have already been developed (flight tests were conducted from 2014 to January 2020, and now serial production is being prepared), and in the future, K-5 SLBMs with a range of over $5,000 \mathrm{~km}$ will be developed. This shows that the sea-based component of India's nuclear forces is primarily focused on building up a retaliatory strike capability against China.

Nuclear weapons, which could be classified as tactical, in India are quite rare. We should call nuclear gravity bombs and short-range missiles from the Prithvi family. The latter are non-sophisticated and have a low accuracy. At the same time, it should be noted that there is no such notion as "tactical" nuclear weapons in the discourse of Indian politicians and the military. In India all types of nuclear weapons are considered strategic and subordinate to a single objective.

The growth of battlefield nuclear weapons capabilities is possible in the near future and is mainly due to the development of cruise missiles. The prospective subsonic cruise missile Nirbhay is among the systems potentially capable of carrying nuclear weapons. The BrahMos supersonic cruise missile, designed for three types of deployment (ground-based, sea- and air-launched), is also considered a possible nuclear delivery vehicle. Its high accuracy and resilience 
to air defense/missile defense may provide additional conventional counterforce capabilities, including ability to strike against hardened targets such as tactical nuclear weapons storage facilities. ${ }^{12}$

In addition, India is testing a family of new tactical ballistic missiles with a range of 150-200 km (Prahaar, Pranash). So far there have been no reports of possible equipping them with nuclear warheads, but it is noted that technically there are no obstacles to this.

\section{Nuclear doctrine of Pakistan}

The Pakistani nuclear doctrine was originally shaped as exclusively aimed at deterring India.

Pakistan began nuclear developments back in 1953 when the Pakistan Atomic Energy Committee was established. The move itself was prompted by reports that India was working in the nuclear field; in 1965, Pakistani Foreign Minister Zulfikar Ali Bhutto formulated the Pakistani position as follows: "If India builds the bomb, we will eat grass or leaves, even go hungry, but we will get one of our own bomb. We have no other choice." Work on nuclear weapons intensified after Pakistan's defeat in the Third Indo-Pakistani War in 1971, when India demonstrated complete conventional superiority over Pakistan. As a result, immediately after the testing of the Indian nuclear device in 1998, Pakistan conducted its own tests, declaring itself a nuclear power.

Pakistan has not published its nuclear doctrine since nuclear testing, believing that it would be more advantageous to remain uncertain in this regard, as it would prevent the Indians from getting information about the "red lines" and the threshold for the use of nuclear weapons. This, however, does not mean that Pakistan does not have a doctrine, at least in the form of a set of beliefs and ready-made solutions. However, its content can only be established from indirect sources: relatively rare publications in the open press, statements of Pakistani military and politicians.

${ }_{12}$ The Hindu, 'BrahMos Successfully Penetrates Hardened Targets in Army Test', 18 Nov. 2013. 
Pakistan's current nuclear doctrine is commonly referred to as "full-spectrum deterrence," and its development has followed the path of increasing the capability and range of its military assets, including its tactical nuclear arsenal. Its provisions are not exactly known, but according to a number of testimonies Pakistan regards the idea of nonuse of nuclear weapons against non-nuclear-weapon states as a working model, reserving the right of first use against "an aggressor armed with nuclear weapons, such as India." 13

The basis of Pakistan's nuclear doctrine is the provision to prevent India from engaging in aggression using conventional or nuclear weapons, and in the event of such aggression, to prevent India from winning the war by inflicting unacceptable damage. Since Pakistan does not aim to win the war, this, on the one hand, broadens the range of options available and, on the other hand, allows for more economical policies consistent with the idea of minimum credible deterrence.

For some time, Pakistan has focused on countervalue options for the use of nuclear weapons against Indian cities. For this purpose, a medium-range missile capability $(1,000-2,000 \mathrm{~km}$; the Shaheen and Ghauri missile families) was developed, the main purpose of which was to hit land-based targets deep inside India. Counterforce missions in the frontline were assigned to Ghaznavi missiles (up to a range of $300 \mathrm{~km}){ }^{14}$

A key point in Pakistan's nuclear doctrine is the provision that nuclear weapons can be used first. Given India's superiority in conventional weapons, there is full consensus among Pakistan's military and political elites on this issue. The effectiveness of such a strategy depends entirely on timely information on the movements of Indian forces, their combat capabilities and the status of conventional

13 Testimony of an expert, former Pakistani Air Force officer Khalid Banuri (December 2011). Kerr, P.K., and Nikitin, M.B., Pakistan's Nuclear Weapons, CRS Report RL34248, Washington, DC, Congressional Research Service, 1 Aug. 2016, p. 10.

${ }^{14}$ Ahmed, M., 'Pakistan's Tactical Nuclear Weapons and Their Impact on Stability', Carnegie Endowment for International Peace, 30 June $2016<$ https:// carnegieendowment.org/2016/06/30/pakistan-s-tactical-nuclear-weapons-and-theirimpact-on-stability-pub-63911>. 
and nuclear weapons, which in turn places increased demands on Pakistan's intelligence and operational readiness of nuclear weapons. Possible threats include the development of capabilities and strategies for the use of Indian conventional forces, India's development and procurement of precision-guided weapons and BMD systems, and India's overall increase in military strength, which could lead New Delhi to the false conclusion that it is possible to conduct a successful military campaign against Pakistan even though it has nuclear weapons.

According to statements by Pakistani officials, General Khalid Kidwai in particular, Pakistan may use nuclear weapons when it considers its existence as an independent state to be in danger. This may happen in the following cases: ${ }^{15}$

- if India attacks Pakistan and seizes large portion of its territory;

- if India destroys a large part of the Army or Air Forces of Pakistan;

- if India effectively applies the strategy of economic strangulation of Pakistan;

- if India provokes a widespread political destabilization within Pakistan.

Thus, any major success of India's conventional forces is likely to result in Pakistan's first nuclear strike. The large-scale Indo-Pakistani conflict, which India would not necessarily lead with the overstretching of all frontline and rear forces, will inevitably become a total war for Pakistan.

\section{"Cold Start": impact on Pakistani nuclear strategy}

The gradual transformation of Pakistan's "minimum credible deterrence" into "full-spectrum deterrence" by the early 2000 s is believed to be driven by the development of India's conventional forces and doctrine of their use against Pakistan. The so-called "Cold Start"

${ }^{15}$ Ghosh, A., Chakraborti, T., Majumdar, A. J., and Chatterjee, S. (eds.), India's Foreign Policy, New Delhi, Repro India, 2009, pp. 93-94. 
doctrine implies that mechanized units of the Indian Armed Forces deployed in Punjab and Rajasthan carry out an offensive operation with minimal preparation time, at a high tempo and with intensive use of precision-guided weapons deep in the enemy combat formations. ${ }^{16}$ (Some observers elevate this concept to the doctrine of "operational manoeuvre groups", established in the USSR in the late 1970s to conduct a deep operation on the European theater). ${ }^{17}$ Mobile groups are kept on high alert, and such an operation can start as early as the second or third day after the decision is made. ${ }^{18}$

"Cold Start" was not only the result of a series of IndoPakistani crises that showed the low combat readiness of India's Armed Forces and the weak suitability of their peacetime groupings for rapid response. One of the reasons was an attempt to develop a plan for a decisive operation against Pakistan, which, however, could have been conducted below the obvious threshold for the use of nuclear weapons.

Pakistan's response included giving greater importance to tactical nuclear weapons, including directly battlefield nuclear weapons,${ }^{19}$ that could be used against advancing Indian Armed Forces groupings. ${ }^{20}$ Since Pakistan is inferior to India in the capabilities of

${ }^{16}$ Ladwig, W. C., 'A Cold Start for Hot Wars? The Indian Army’s New Limited War Doctrine', International Security, vol. 32, no. 3, Winter 2007/08, pp. 158-190.

17 Khan, F.H., Going Tactical: Pakistan's Nuclear Posture and Implications for Stability, Proliferation Papers \# 53, Paris, IFRI Security Studies Center, Sept. 2015, p. 26.

18 Gady, F.-S., 'Is the Indian Military Capable of Executing the Cold Start Doctrine?' The Diplomat, 29 Jan. 2019.

19 Panda, A., 'Pakistan Clarifies Conditions for Tactical Nuclear Weapon Use Against India ', The Diplomat, 20 Oct. 2015.

20 This piece deals only with the military and political ("signal") aspects of such a strategy. The assessment of purely military expediency of such actions goes beyond its scope. It should be noted that the idea of Pakistan's use of TNWs has been repeatedly criticized from the point of view of quantitative evaluation of the low effectiveness of single strikes by low-yield nuclear warheads against tactical formations of advancing mechanized forces. See, for example: Nayyar, A. Y., and Mian, Z., 'Pakistan and the Nasr Missile: Searching for a Method in the Madness', Economic and Political Weekly, no. 39, Sept. 2015; Tellis, A. J., India's Emerging Nuclear Posture: Between Recessed Deterrent and Ready Arsenal, Santa Monica, CA, RAND Corporation, 2001, p. 133. 
conventional forces, conducting such an Indian operation with scale and intensity above a certain level is considered a threat to the existence of the Pakistani state. According to Pakistan's perceptions, this may require the dosed use of TNWs to de-escalate the crisis, while avoiding an overreaction in the form of strategic strikes against Indian cities. In turn, the very existence of a diverse tactical nuclear arsenal is seen in Pakistan as a deterrent, dissuasive measure against India conducting such an operation.

The Nasr road-mobile tactical missile with a range of $60-70 \mathrm{~km}$ and Abdali missile with a range of $180-200 \mathrm{~km}$ were chosen as the main countermeasures to the "Cold Start." ${ }^{21}$ Both of them reportedly have counter-BMD manoeuvre programs on their trajectories, making it difficult to cover deployed tactical formations from a missile strike. ${ }^{22}$ In addition, the nuclear version of the Nasr has a built-in, not mounted, warhead and has a short start preparation time. ${ }^{23}$

Another aspect of "full-spectrum deterrence" was the development of a weapons to launch nuclear strikes throughout India. It was a ballistic missile Shaheen III with a range of $2,750 \mathrm{~km}$. According to the Pakistani military, the choice of range is not arbitrary and related to the need to ensure the strikes against India's most remote military facilities, in particular the Andaman and Nicobar Islands naval bases. ${ }^{24}$ Officially, this is done to prevent India from retaliating with the remaining nuclear forces. However, it is not clear how this statement is combined with the idea of a baseline scenario in the form of limited first use of TNWs on the battlefield. Such missiles rather look like a new generation of weapons for attacking cities in India or for a first strike on key military targets.

\footnotetext{
21 'NASR and Pakistan's Nuclear Deterrence', Eurasia Review, 2 May 2011.

22 Ansari, U., 'Pakistan Continues Short-Range Ballistic Missile Tests', Defence News, 18 Feb. 2013.

${ }^{23}$ Clary, C. and Narang, V. 'Doctrine, Capabilities, and (In)Stability in South Asia', p. 100, in: Deterrence Stability and Escalation Control in South Asia, eds. M. Krepon and J. Thompson, Washington, DC, The Stimson Center, 2013.

${ }^{24}$ Lavoy, P. and Kidwai, K., A Conversation with Gen. Khalid Kidwai, Transcript, Carnegie International Nuclear Policy Conference 2015, 23 Mar. 2015, p. 10.
} 
Another area of development is nuclear cruise missile: airlaunched $\left(R a^{\prime} a d\right)$, as well as ground-based and sea-launched (Babur). China's Beidou satellite navigation system should play a significant role in ensuring the cruise missile's combat employment. ${ }^{25}$

Official Pakistani statements give submarine-launched Babur-3 cruise missile the role of a "credible retaliatory mean," but at the moment there are no serial carriers for it. Presumably, their role could be played by three refurbished Agosta 90B (Khalid-class) non-nuclear submarines commissioned by the Pakistani Navy in 1999-2008, and later by new Chinese-built non-nuclear submarines. The full deployment of the seabased leg of nuclear triad, with regular combat patrol missions, will require the establishment of a sustainable command, control and communication system, as well as addressing the issue of delegating the use of nuclear weapons to submarine commanders.

It should be noted that low-altitude subsonic cruise missiles are highly resilient to the existing air defense systems of the Indian Armed Forces and simultaneously complement tactical ballistic missiles at the battlefield. Another problem is the fact that the Babur and Ra'ad missile families are deliberately designed as dual-capable systems. This increases the chance of misinterpretations in case of rapid escalation of armed conflicts under conditions of incomplete information and brings the risk of a miscalculated preemptive strike on nuclear delivery vehicles, which may cause an unintentional nuclear escalation.

The development of MIRV technology in Pakistan should be seen as a natural response to India's missile defense efforts, as well as a response to India's deployment of MIRVed missiles. ${ }^{26}$ The technology is currently being developed for a version of the Shaheen III called Ababeel; it is technically possible to equip Shaheen II missiles with

25 Ansari, U., 'Pakistan Employs China's Beidou Guidance System', Defence News, 3 May 2013.

26 Tasleem, S., 'No Indian BMD for no Pakistani MIRVs', Stimson Center, Off

Ramps Initiative Paper, 2 Oct. 2017. 
a range of 1,500-2,000 km. ${ }^{27}$ The challenge is complicated, among other things, by the limited amount of weapons-grade nuclear materials available. ${ }^{28}$ It should be noted that in this situation there is a high probability of misinterpretation of the opponent's motivation. India may believe that it is necessary to build a missile capability with MIRVs primarily in the aim of deterrence of China. Pakistan, on the other hand, by entirely taking the advent of such systems personally, may join a new round of nuclear missile race in the region.

The evolution of Pakistan's nuclear doctrine was reflected in the 2011 official statements on the readiness and ability to use tactical nuclear weapons. This is due in part to Pakistan's desire to portray itself as a peace-loving responsible power: as the massive use of nuclear weapons against Indian cities appears disproportionate, Islamabad has placed emphasis on the use of nuclear weapons on the battlefield. The extent to which this emphasis is stabilizing bilateral deterrence is a matter of debate. By limiting the scope of a potential conventional conflict initiated by India, it simultaneously lowers the threshold for Pakistan's use of nuclear weapons, which could trigger a rapid escalation up to the exchange of massive nuclear strikes. Besides, it raises the issue of the escalation threat in case of India's attempts to launch preemptive targeted non-nuclear strikes on TNWs delivery vehicles.

Discussions on the possible evolution of Pakistani nuclear doctrine focus on the following points: ${ }^{29}$

- the ability of Pakistani nuclear forces to ensure permanent readiness for the first strike;

\footnotetext{
${ }^{27}$ Khan, F.H. and Ahmed, M., 'Pakistan, MIRVs, and Counterforce Targeting', in: The Lure and Pitfalls of MIRVs: From the First to the Second Nuclear Age, eds. Krepon, M., Wheeler, T. and Mason, S., Washington, D.C., Stimson Center, May 2016, p. 157.

28 Ibid, p. 166.

29 The matter is discussed in details in: Tasleem, S., 'Pakistan's Nuclear Use Doctrine', Carnegie Endowment for International Peace, 30 Jun. $2016<\mathrm{https}$ :// carnegieendowment.org/2016/06/30/pakistan-s-nuclear-use-doctrine-pub-63913>.
} 
- the issue of delegation of authority in the context of abandoning the concept of a massive nuclear strike in favor of a gradual response using TNWs and the development of the sea-based leg of the nuclear triad;

- prospects for the development of reconnaissance, early warning, command, control and communications systems;

- the need to improve and build tactical nuclear capabilities and dragging in an arms race amid an obviously weak economic base.

At the same time, the issue of escalation control remains beyond the attention of experts, military and politicians. As far as it can be learn from open sources, Pakistani elites (as well as Indian elites) either have no understanding how to stop the escalation at all, or all documents on this issue are highly classified in order not to damage the country's defense capability. The only option available in the public press is to involve the international community in resolving the crisis.

In general, it may be noted that within the official discourse both in India and Pakistan, a large-scale war that escalates into a nuclear war appears to be an extremely unlikely event. Both sides declare confidence that nuclear deterrence will help prevent war. There are frequent appeals to the experience of the Kargil conflict and the last Indo-Pakistani crisis in 2019, when both sides proved themselves to be responsible powers without seriously considering the possible use of nuclear weapons.

India and Pakistan have made some progress in stabilizing the situation over the past thirty years through confidence-building measures. In December 1988, an agreement was signed on the exclusion of attacks on "nuclear installations and facilities," which means nuclear weapons production facilities, nuclear power plants and research reactors, as well as fissile material storages (but neither nuclear 
warheads storages nor nuclear forces bases). ${ }^{30}$ In February 1999 the socalled Lahore Declaration was signed, under which India and Pakistan adopted a set of confidence-building measures in the field of nuclear risk reduction and agreed not to conduct any more nuclear tests unless "extraordinary events have jeopardised [their] supreme interests." ${ }^{31}$ In the early 2000 s, the confidence-building measures were expanded to include an intensified bilateral expert dialogue.

However, the real dynamics of the nuclear capabilities of both countries are a source of instability and possible crisis escalation. Political complications may lead to further antagonisation of the countries as a result of the transformation of the Indian nation into a new community solely based on Hinduism, as implied by the BJP party's program, or of the further increase in Islamist influence in Pakistan. The risk remains that the breakdown of the regional balance and ill-conceived actions by politicians could lead to conflict and its nuclear escalation.

The likelihood of a nuclear escalation scenario is supported by doctrinal provisions of at least one of the parties (Pakistan) considering de-escalation through a limited first nuclear strike, as well as active development of tactical nuclear arsenals that meet such provisions. A number of knowledgeable observers have noted that Pakistan's nuclear doctrine is essentially a deliberate manipulation of nuclear risks with maximal cover-up of the "red lines." 32 Tactical nuclear weapons are seen as a targeted tool to create uncertainty that should constrain the scope of India's actions in a conventional conflict.

The evolution of India's views on the use of nuclear weapons is also showing dangerous signs. The first of these is the debate on giving the nuclear doctrine "flexibility," which may also be indicative of attempts to expand nuclear battlefield capabilities (in fact, by

\footnotetext{
30 Agreement Between India and Pakistan on the Prohibition of Attack Against Nuclear Installations and Facilities (India-Pakistan Non-Attack Agreement), 31 Dec. 1988.

31 The Lahore Declaration. Peace Agreements Digital Collection, United States Institute of Peace <https:/www.usip.org/sites/default/files/file/resources/collections/ peace_agreements/ip_lahore19990221.pdf $>$.

32 Khan, op.cit, p. 29.
} 
increasing the capacity for a symmetrical response to Pakistan). The second feature is the obvious elements of the "left-of-launch" concept. Its implementation may lead to the final appearance of the doctrine of combined (nuclear and precision-guided conventional) preemptive counterforce strikes against Pakistan's nuclear forces, as well as an emphasis on the development of missile defense systems. The introduction of such a doctrine may destabilize the nuclear balance in Indian subcontinent and is likely to accelerate the nuclear arms race that is already underway there.

Thus, it should be concluded that despite the obviously restrained political framework for nuclear strategies, both sides are actively developing nuclear weapons and gaining new capabilities. These actions have latently eroded the threshold for the use of nuclear weapons and, in line with the principle of "capabilities over intentions," have created grounds for a gradual revision of nuclear doctrines towards their greater "flexibility" and, indeed, the creation of doctrinal basis for initiating and conducting limited nuclear war. The question remains open as to how the strategic cultures of both countries, which have been shaped over decades, will be able to counteract politically this gradual erosion of the "nuclear threshold." 


\section{TRANSFORMATION OF THE ISLAMIC STATE}

\section{Stanislav IVANOV}

The military defeat of the Islamic State terrorist organization ${ }^{1}$ (IS, also known by the acronyms ISIL and Daesh) in Iraq and Syria has led to the liquidation of the Islamic Caliphate - the quasi-state of radical Islamists, which had existed in these countries in 2014-2017. As of that period, IS fighting forces had advanced heavy weapons and military equipment, significant financial and material resources, with the total number of militants reaching 60,000 people and more. ${ }^{2}$ They enjoyed the support of part of the population in the occupied territories (Sunni Baasists in Iraq, Syrian Arab tribes living beyond the Euphrates, etc.).

At that time, volunteers and mercenaries from 86 countries, totaling about 30,000 militants, fought in the ranks of the IS. ${ }^{3}$ IS fighters had good chances of taking over of Baghdad and Damascus and even seizing power in Iraq or Syria. In addition, the Islamic State and its affiliated groups operated in Afghanistan, Pakistan, Egypt, Libya, Nigeria, Yemen, Somalia, the Democratic Republic of Congo and several other countries. IS recruiters have been actively increasing the number of terrorist cells and affiliates in Morocco, Algeria, Tunisia, Saudi Arabia, Lebanon, Indonesia, the Philippines, China, the United States, the Caucasus, as well as in the CIS and European countries. ${ }^{4}$ It took the military efforts of the international coalition and many individual countries (over 65 states), including Russia and the United States, as well as Iranian and pro-Iranian contingents, Kurdish militia

\footnotetext{
1 This organization is prohibited in Russia.

2 ISIL: formula for modern terror, ed. by A. V. Glazova, A. V. Ataev, Ye. S. Birukov, Moscow, Russian Institute for Strategic Studies (RISI), 2017, p. 58 [In Russian].

3 Ibid, p. 13.

4 Sazhin, V., 'Islamic Caliphate is dead, but its dangerous and infectious ideology is alive' [Electronic resource], International Affairs, 15 Mar. $2019<\mathrm{https} / /$ en.interaffairs.ru/article/islamic-caliphate-is-dead-but-its-dangerous-andinfectious-ideology-is-alive/ $>$.
} 
and the remnants of the Syrian and Iraqi armies to defeat the largest groupings of the Islamic State and free the Caliphate's capital city of Raqqa from the militants.

Unfortunately, it cannot be said today that the Islamic state is totally eliminated, although tens of thousands of the IS fighters and members of their families have been arrested and are in prisons or detention camps in Iraq and Syria. Some of the IS militants from the local population have returned to their places of residence and temporarily ceased their terrorist activities, some of them are hiding in remote desert and mountainous areas or continued their activity underground. Since early 2019 alone, the IS militias have carried out several hundred terrorist acts and attacks in Iraq and Syria. The Pentagon estimates the number of IS fighters in both countries to be between 14,000 and 18,000 people. $^{5}$ The liquidation of the Caliph Ibrahim al-Badri (alias Abu Bakr al-Baghdadi) by the U.S. Special Forces in northwestern Syria on 26 October 2019, was not a turning point in the fight against this organization. One of his close associates Amir Mohammed Abdul Rahman al-Mawli al-Salbi, who was among the founders of the Islamic State (he is also known as Haji Abdullah or Abdullah Kardash), ${ }^{6}$ soon became al-Baghdadi's "successor." "The Islamic State group is weakened, but a resurgence is possible if the United States leaves Iraq," U. S. Major General Alexus Grynkewich, the deputy commander for the international anti-jihadist coalition in Iraq and Syria, said in this regard. He added that the IS "certainly still remains a threat." 7

\footnotetext{
5 Gashkov, I., 'Strikes from the underground. The IS is not defeated neither in Iraq, nor in Afghanistan, nor in Syria', TASS, 21 Aug. $2019<$ https://news.rambler.ru/ middleeast/42696840-udary-iz-podpolya-ig-ne-razbito-ni-v-irake-ni-v-afganistaneni-v-sirii> [In Russian].

6 'The Guardian named the new IS leader', Gazeta.ru, 21 Jan. $2020<$ https://www. gazeta.ru/army/news/2020/01/21/13939472.shtml> [In Russian].

7 'The IS can rebuild its forces if the coalition leaves Iraq', Nezavisimaya gazeta, 23 Jan. $2020<$ http://www.ng.ru/news/668717.html > [In Russian].
} 


\section{IS in the Middle East region and Asia}

Currently, one can observe an increasing activity of the IS units in countries affected by armed conflicts, such as Libya and Yemen, as well as Afghanistan, Pakistan and other Central Asian countries. There are preconditions for establishment of a new Islamic Caliphate in the territory of the so-called Greater Khorasan, which includes, along with Afghanistan and Pakistan, the eastern provinces of Iran, the Xinjiang Uyghur Autonomous Region of China, Tajikistan, Uzbekistan, Kazakhstan, Kyrgyzstan, and Turkmenistan.

The ideology of extreme Sunni radical Islam (takfirism, jihadism) adopted by the IS remains very attractive to many Muslims. It successfully fills the vacuum of ideology in many countries of the Middle East, Africa and Asia, having arisen against the backdrop of the collapse of ideas of Arab and other socialism and weakening of state institutions. Applying modern information technologies (Internet, social networks, radio, mobile communications), the Islamic State leaders and recruiters actively take advantage of internal and regional conflicts, growing public dissatisfaction with authorities, difficult social and material situation, poverty, unemployment to incite hatred towards the infidels. ${ }^{8}$ In Afghanistan's Nangarhar province, they recently launched their regional "Caliphate" radio station. Reportedly, the IS is still receiving financial and other support from its sponsors in the Persian Gulf and other Muslim countries. ${ }^{9}$ Saudi Arabia and other Gulf monarchies seem to regard radical Islamists as a force that can help them overthrow the Assad's Alawite regime in Syria, restore the rights of the Arab Sunni minority in Iraq, and limit the influence of Iranian Shiite fundamentalists in Yemen, Lebanon, Bahrain, and other Arab countries. As a result, large territories of Iraq, Syria and Yemen continue to be a zone of regional Sunni-Shia armed confrontation.

\footnotetext{
${ }^{8}$ Islamists regard as infidels atheists, pagans or representatives of other religions who do not recognize or reject the tenets of Islam.

9 ISIL: formula for modern terror, p. 70.
} 
There are suggestions that the Turkish leadership is not giving up support for the Islamists in Syria, Egypt and Libya, although Ankara's main focus are the radical Islamist organizations Muslim Brotherhood and Hay'at Tahrir al-Sham (formerly known as Jabhat alNusra). In 2014-2017, Turkish authorities and individuals cooperated very closely with the IS (in trading oil, museum artifacts, agricultural products, etc.). ${ }^{10}$ An overwhelming number of foreign jihadists had entered the Islamic Caliphate through Turkey, where they also received medical treatment, through informal channels, as well as weapons and ammunition.

Atheists and adherents of other religions continue to be attracted by the networks of Islamist recruiters; contemporaneously with their conversion to Islam, they are being involved in extremist and terrorist activities. Growing migration flows from Muslim countries affected by conflicts are facilitating Islamization of Europe and other continents and intensification of activity of radical Islamist groups around the world. Some experts call the ongoing processes "renaissance" of Islam as one of the youngest and most attractive religions of our time. This is accompanied by radicalization of Muslim communities and creation of new terror-oriented organizations in their midst.

Not leaving hopes to restore their position in Iraq and Syria, the IS leaders are trying to strengthen their position in northern Pakistan. From here, they are reportedly planning to penetrate into South and Central Asia countries and to recreate the Islamic Caliphate within new, broader borders. The Islamic state is trying to use its potential and ideology of jihad to enter into various military and political groups in Afghanistan and its neighboring countries. ${ }^{11}$

In the summer of 2018, the first armed clashes between the IS and Afghan Taliban fighters ended in defeat of the Caliphate proponents, but by early 2020 the situation had slightly changed in favor of the Islamic State. The IS militants were able to seize some of the Taliban's strongholds and bases in the north of the country in close

10 'RT published new material indicating Turkey's ties with IS fighters', Russia Today, 31 Mar. $2016<$ https://russian.rt.com/article/156373> [In Russian].

${ }^{11}$ ISIL: formula for modern terror, p. 191. 
proximity to the Afghan-Turkmen border and the Tora Bora caves on the Afghan-Pakistani border, ${ }^{12}$ where former al-Qaeda ${ }^{13}$ leader Osama bin Laden was hiding out at one time.

The IS fighters have also managed to push back Taliban ${ }^{14}$ units in Nangarhar and Kunar provinces in eastern Afghanistan, launch a massive diversionary and terrorist war in several other Afghan provinces and create deeply entrenched cells in Pakistan's capital Kabul. The series of terrorist attacks in Kabul organized by the IS has culminated in the largest of them, when a suicide bomber detonated an explosive device at a wedding ceremony in Kabul on August 17, 2019, killing 63 and injuring 180 people. Strengthening of the IS positions in the eastern part of the country is particularly dangerous because almost half of all Afghan drug trafficking passes through it. Previously, drug revenues in this region were accumulated by the Taliban, but now Jihadists from the IS, who regard opium, heroin and cannabis trade not only as sources of funds but also as a means of "elimination of infidels," have also gained access to drug trafficking. ${ }^{15}$ In parallel with takeover of a portion of the narcotics business in Afghanistan (de facto wrestling control from Taliban groups), the IS Jihadists are attempting to gain control over mining and international transit cargo.

On 29 February 2020 after several years of difficult negotiations, the United States and the Taliban have signed a peace agreement in the Qatar's capital Doha. This agreement was the Taliban's largest diplomatic and political success in history (in the signed document, it appears as the Islamic Emirate of Afghanistan). The agreement stipulates that Taliban fighters will lay down their arms and stop terrorist and military activities, while the United States, in turn, should

12 'ISIL prepares a bridgehead in Afghanistan for invasion of Central AsiaPatrushev', Sputnik News, 18 Dec. $2019<$ https://uz.sputniknews.ru/world/ 20191218/13043850/IGIL-gotovit-v-Afganistane-platsdarm-dlya-vtorzheniya-vTsentralnuyu-Aziyu---Patrushev.html $>$ [In Russian].

13 This organization is prohibited in Russia.

14 This organization is prohibited in Russia.

15 'Russian Foreign Ministry said that ISIL receives income from Afghan drug trafficking,, "Zvezda" TV channel, 7 Apr. $2017<$ https://tvzvezda.ru/news/ vstrane_i_mire/content/201704070226-2ayq.htm> [In Russian]. 
refrain from using force. Moreover, the Taliban provided guarantees that there will be no threat to the USA and its allies from the territory of Afghanistan from other radical Islamist groups like al-Qaeda and Islamic state.

Withdrawal of the US troops and their NATO allies from Afghanistan may take place within 14 months after the signing of the document (provided the terms of the agreement are met by the Taliban). The USA intends to reduce its military forces in Afghanistan from 13,000 to 8,600 within 135 days of the US-Taliban agreement, depending on the Taliban fulfilling their obligations under it. The contingent of each of the US allied nations in Afghanistan will come down in proportional numbers. The United States also plans to free five of its military bases in Afghanistan.

Under the agreement, the US agreed to remove members of the Taliban from the US sanctions lists and from the US wanted lists. It also outlines negotiations and engagement with the rest of the UN Security Council to ensure that the latter also removes the Taliban from their national sanctions lists. The Afghan government will release up to 5,000 Taliban prisoners in exchange for 1,000 security personnel held by the Taliban. Washington committed not to interfere in the country's domestic politics, but the USA will annually provide funds for training, advising and equipping Afghan security forces. The four-page agreement contains some other points; one also cannot rule out that there were some secret agreements between the parties, particularly on security measures for US soldiers during troop withdrawals. ${ }^{16}$

It is too early to talk about whether the agreement reached will be durable and realistic. It has opponents among both the Taliban and government circles in Kabul and Islamabad. The leaders of the

\footnotetext{
16 Asatryan, G., 'U.S. agreement with the Taliban: recognition of American failure in Afghanistan?', TASS, 2 Mar. $2020<$ https://tass.ru/opinions/7876949> [In Russian].
} 
so-called Northern Alliance - Tajiks, Uzbeks and other minorities ${ }^{17}$ do not conceal their apprehension about a possible strengthening of the Pushtun majority in the country.

The IS leaders actively use this agreement for propagandistic purposes in order to discredit Taliban leaders by denouncing them as traitors to jihad and sowing divisions within their ranks. At the same time, jihadists are trying to provoke a new spiral of civil war in the country, ultimately seeking to weaken the position of all participants in the intra-Afghan confrontation: federal authorities, the Taliban, Northern Alliance supporters, Hazara Shiites. IS representatives are actively working to attract to their side the most radical talibs who oppose the agreement between the United States and Taliban.

It should be noted that the Afghan Taliban movement is very diverse and heterogeneous, including with regard to interests of field commanders and ordinary fighters. As was mentioned above, there have been fierce fighting between the Taliban and the IS, ${ }^{18}$ with mixed results, which occurred, among other things, because some Taliban units refused to follow instructions from their leaders (and, apparently, their Pakistani "curators") to collaborate with the Islamic State and continued to fight with IS jihadists. At the same time, since 2019, there have been an increasing number of cases when Taliban militants had been ceasing resistance and taking the Afghan government's side. ${ }^{19}$

\footnotetext{
17 For example, the son of the influential field commander Ahmad Shah Massoud, Ahmad Massoud Jr., stated in 2019 that there was a need to create a reliable counterbalance to Taliban in order to prevent their usurpation of power in the country and a repetition of the tragic events of 1996. According to him, Panjshir valley should become the center of a new political alliance of northerners and a bulwark of resistance to the Taliban. See: Subbotin, I., 'The North of Afghanistan is Preparing for Uprising', Nezavisimaya Gazeta, 4 Sep. $2019<$ http://www.ng.ru/ world/2019-09-04/1_7667_afganistan.html> [In Russian].

18 'Why the Afghan Taliban are at war with the Islamic State', BBC Russian Service, 19 Dec. 2015 <https://www.bbc.com/russian/international/2015/12/ 151218 taliban_fighting_isis $>$.

19 Serenko, A., "The Afghan Taliban began abandoning "jihad", Nezavisimaya Gazeta, 23 Sept. $2019<$ http://www.ng.ru/world/2019-09-23/100_afgan2309_2. html> [In Russian].
} 


\section{Likelihood of increased IS activity in Central Asian and CIS countries}

The level of terrorist threat in the Central Asian countries has been quite high during the last decades. This was facilitated by a number of factors: social and economic problems, high unemployment, especially among young people, ethnic and national separatism, religious extremism, clanishness and corruption of the authorities, illicit drug and arms trafficking, illegal migration, difficulties in forming Muslim societies in the post-Soviet period. With the collapse of the Soviet Union, control of state borders of the Central Asian states, including their borders with Afghanistan, weakened markedly. This fact was used by various radical Islamist groups, primarily al-Qaeda, the IS, Islamic Movement of Uzbekistan (IMU), Jamaat Ansarullah, and East Turkestan Islamic Movement. Afghani nationalist organizations are raising the issue of reunification of divided peoples - Tajiks, Uzbeks, Turkmens, Kyrgyzs, and others.

Islamic Movement of Uzbekistan (IMU), the extremist group allied with the Afghan Taliban, has been active in Central Asia for a long time. IMU leaders interact more and more closely with the Islamic State in Afghanistan, that is why the Central Asian countries are facing increasing threats from the IS, which is expanding its strength in the northern Afghani provinces. The ranks of this terrorist organization are growing through recruiting not only Afghan Pashtuns, Tajiks, Uzbeks, and Turkmens, but also citizens of Tajikistan, Uzbekistan, and other post-soviet Central Asian countries. The number of recruited fighters, according to various estimates, has already reached several thousand people. According to media reports, in 2019 the State Security Service of Uzbekistan detained four citizens of the country who were planning to go to Syria and take part in hostilities on the terrorist side. Two other 
fighters from Fergana region were detained at the airport on their flight to Moscow. They had received money from a Kyrgyz resident to travel to Syria "for the purpose of jihad." 20

The only way to counteract the extremist and terrorist activities of the IS and other Islamist groups in Central Asian consists in closer cooperation between the security agencies of the region's countries, especially between the authorities of Afghanistan and Pakistan and neighboring states. Much will also depend on the ability of the Afghanistan leadership and Central Asian countries to control the situation in their countries and at their state borders. Any aggravation of the domestic political situation in Afghanistan and neighboring countries will inevitably lead to an increased terrorist threat not only for the Central Asian states, but also for the southeast borders of the Russian Federation. For its part, Moscow is paying serious attention to coordinating the efforts of SCO and CSTO as regional organizations in combating the terrorist threat from Afghanistan.

It is unlikely that the IS leaders expect to repeat their successes in Syria and Iraq and establish their caliphate in Central Asia in the near future. Rather, they aim to infiltrate local Muslim communities and integrate into their existing network of extremism, terrorism and organized crime (trafficking of drugs, weapons, ammunition, etc.). A high threat to the Central Asian republics is the activation of previously established "sleeping jamaats" and the formation of a network of autonomous cells and "lone wolf" terrorists who have succumbed to propaganda and recruitment by jihadists. ${ }^{21}$

\footnotetext{
20 'In Uzbekistan, four citizens were prevented from leaving for Syria to join terrorists', Nezavisimaya Gazeta, 24 Sept. $2019<$ http://www.ng.ru/cis/2019-0924/5 7684 news2.html> [In Russian].

21 "Lone wolves" in "sleeping jamaats": how the IS creates the center of the Caliphate in Central Asia', Sputnik Tajikistan, 19 Feb. $2019<$ https://tj.sputniknews. ru/afghan/20190208/1028209079/verbovka-isis-afghanistan-central-asia-halifat. html $>$ [In Russian].
} 


\section{Threat of IS penetration into Russia}

The activities of the Islamic State in Russia's neighboring countries directly affect national interests of the Russian Federation and threaten its national security. According to the Chairman of the Council of Muftis in Russia Ravil Gainutdin, over the past 22 years, the number of Muslims in Moscow alone has increased from 800,000 to 3-4 million people. ${ }^{22}$ Similar processes are taking place in St. Petersburg and other major Russian cities. Such accelerated Islamization of Russia due to the influx of migrants from Central Asia and Caucasus and high birth rates in the Muslim republics of the Russian Federation promote penetration of extremist Islamist ideology into the country and formation of new terrorist groups and cells.

As the head of Directorate-General on Counteraction of Extremism Major General Oleg Ilinykh reported on 17 September 2019, only in 2019 the Federal Security Service and the Ministry of Internal Affairs revealed clandestine terrorist cells in 17 regions of the country. According to him, the activity of militants of the Islamic state group was stopped in Moscow and Moscow region, Astrakhan, Vladimir, Rostov, Samara, Saratov, Tyumen regions, Krasnodar, Stavropol and Krasnoyarsk krais, republics of Adygea, Dagestan, KabardinoBalkaria, Chechnya, as well as in Khanty-Mansi and Yamalo-Nenets Autonomous Okrugs. ${ }^{23}$ Secretary of the Security Council of Russia Nikolai Patrushev noted that from January till September 2019 law enforcement agencies have detained 152 persons involved in terrorist activity in the Central District of the Russian Federation alone. ${ }^{24}$

\footnotetext{
22 Nodelman, V., 'In Moscow three or four million people profess Islam', Izvestia, 20 Sept. $2019<$ https://iz.ru/923188/valeriia-nodelman/tri-chetyre-millionazhivushchikh-v-moskve-ispoveduiut-islam $>$ [In Russian].

23 'MIA and FSS have discovered terrorist cells in 17 Russian regions since the beginning of the year', $R B C$, 17 Sept. $2019<$ https://www.rbc.ru/ society/17/09/2019/5d807a719a79472342b2db29> [In Russian].

24 Shimaev, R., ' 152 people detained: during eight months of 2019 terrorist attacks were prevented in four cities of the Central Federal District', Russia Today, 4 Oct. $2019<$ https://russian.rt.com/russia/article/674300-cfo-terakty-patrushevstatistika-2019> [In Russian].
} 
In this context, the Russian government is interested in achieving consensus between the moderate wing of the Taliban and the Afghan government in order to reduce the tension in the domestic political situation and prevent the strengthening of radical Islamists, primarily the Islamic state, in Afghanistan and in the region as a whole. Despite the fact that the Taliban, like the IS, is one of the banned organizations in Russia, Moscow does not give up contacts with representatives of the moderate wing of the Taliban and is trying to play a mediating role in the peaceful settlement of the Afghan conflict. Thus, the special representative of the Russian president for Afghanistan Zamir Kabulov has met and held talks with a Taliban delegation in Moscow on September 13, 2019. Unlike the IS, the Taliban focuses on the struggle for power and influence in Afghanistan only and refrains from expanding its ideology to Russia and Central Asia and South Caucasus countries. The authorities in Russia, Tajikistan and Uzbekistan are also using their traditional ties and contacts with the leaders of the former Northern Alliance in Afghanistan to achieve intra-Afghan reconciliation, the formation of a coalition government, and the unity of all patriotic Afghan forces in confronting the new threats posed by IS jihadists. 


\section{PART III. DOCUMENTS AND REFERENCE MATERIALS}

10. Key documents of the Russian Federation on national security, defence and arms control (January-December 2019) 
10. KEY DOCUMENTS OF THE RUSSIAN FEDERATION ON NATIONAL SECURITY, DEFENSE AND ARMS CONTROL (JANUARY - DECEMBER 2019)

Sergey TSELITSKY

\section{Legislative acts}

Ordinance of the Federation Council of the Federal Assembly of the Russian Federation № 47-FC of 13 March 2019 'Statement on the 20th anniversary of the start of the military operation carried out by the North Atlantic Treaty Organization against the Federal Republic of Yugoslavia' Ordinance of the Federation Council of the Federal Assembly of the Russian Federation № 97-FC of 10 April 2019 'Statement of the Federation Council of the Federal Assembly of the Russian Federation regarding destructive policies implemented by the North Atlantic Treaty Organization (NATO) since its establishment in 1949'

Federal Law № 156-FZ of 3 Jul. 2019 'On Suspending the Russian Federation's Compliance with the Treaty Between the United States of America and the Union of Soviet Socialist Republics on the Elimination of Their Intermediate-Range and Shorter-Range Missiles'

The Federal Law was passed by the State Duma (SD) on 18 Jun. 2019, approved by the Federation Council (FC) on 26 Jun. 2019 and signed by the President of the Russian Federation (President) on 3 Jul. 2019.

Under the law, Russia suspends its compliance with the Treaty Between the United States of America and the Union of Soviet Socialist Republics on the Elimination of Their Intermediate-Range and ShorterRange Missiles signed between the Soviet Union and the United States in Washington, DC on December 8, 1987. 
The law stipulates that any decision to resume the Russian Federation's compliance with the Treaty Between the United States of America and the Union of Soviet Socialist Republics on the Elimination of Their Intermediate-Range and Shorter-Range Missiles shall be taken by the President of Russia.

Federal Law № 196-FZ of 26 Jul. 2019 'On ratification of the Shanghai Cooperation Organization Convention on Countering Extremism'

The Federal Law was passed by the SD on 17 Jul. 2019, approved by the FC on 23 Jul. 2019 and signed by the President on 26 Jul. 2019.

Federal Law № 273-FZ of 2 August 2019 'On ratifying the Second Protocol on amendments to the Charter of the Collective Security Treaty Organization of 7 October 2002'

The Federal Law was passed by the SD on 24 Jul. 2019, approved by the FC on 26 Jul. 2019 and signed by the President on 2 August 2019.

Federal Law № 275-FZ of 2 August 2019 'On ratifying the Third Protocol on amendments to the Charter of the Collective Security Treaty Organization of 7 October 2002'

The Federal Law was passed by the SD on 24 Jul. 2019, approved by the FC on 26 Jul. 2019 and signed by the President on 2 August 2019.

Federal Law № 277-FZ of 2 August 2019 'On ratifying the Second Protocol on amending the Agreement on the Legal Status of the Collective Security Treaty Organization signed on 7 October 2002'

The Federal Law was passed by the SD on 24 Jul. 2019, approved by the FC on 26 Jul. 2019 and signed by the President on 2 August 2019.

Federal Law № 363-FZ of 12 November 2019 'On ratifying the Additional Protocol to the Council of Europe Convention on the Prevention of Terrorism' 
The Federal Law was passed by the SD on 22 October 2019, approved by the FC on 6 November 2019 and signed by the President on 12 November 2019.

Federal Law № 365-FZ of 12 November 2019 ' On the Ratification of the Agreement on Using and Further Streamlining Intra-CIS Military Satellite Communications Systems'

The Federal Law was passed by the SD on 24 October 2019, approved by the FC on 6 November 2019 and signed by the President on 12 November 2019.

Federal Law № 368-FZ of 12 November 2019 'Withdrawal of the Declaration made upon ratification of the Protocol additional to the Geneva Conventions of 12 August 1949, and relating to the protection of victims of international armed conflicts (Protocol I)'

Federal Law № 429-FZ of 16 December 2019 'On ratifying the Treaty between the Russian Federation and the Kyrgyz Republic on Cooperation in Military Postal and Courier Service' The Federal Law was passed by the SD on 5 December 2019, approved by the FC on 11 December 2019 and signed by the President on 16 December 2019.

Normative acts of the executive power

President’s Executive Order № 91 of 4 March 2019 'On Suspending the Russian Federation Compliance with the Treaty Between the United States of America and the Union of Soviet Socialist Republics on the Elimination of Their Intermediate-Range and Shorter-Range Missiles' 
Proceeding from the need to take urgent measures in connection with the violation by the United States of America of its commitments under the Treaty Between the United States of America and the Union of Soviet Socialist Republics on the Elimination of Their IntermediateRange and Shorter-Range Missiles of December 8, 1987, I hereby resolve:

1. In accordance with Item 4 of Article 37 of the Federal Law No. 101-FZ dated July 15, 1995, on International Treaties of the Russian Federation, to suspend the implementation of the Treaty Between the United States of America and the Union of Soviet Socialist Republics on the Elimination of Their Intermediate-Range and ShorterRange Missiles of December 8, 1987, until the United States of America rectifies its violations of the said Treaty or until it expires.

2. The Ministry of Foreign Affairs of the Russian Federation is to send the signatory states of the Treaty referred to in Item 1 hereof a notice on the suspension of its implementation.

3. This Executive Order enters into force on the day of its signing.

President’s Executive Order № 97 of 11 March 2019 'On approving the Fundamentals of State Policy in the Field of Chemical and Biological Security up to 2025 and beyond'

In order to implement the state policy of the Russian Federation in the field of chemical and biological safety, the Fundamentals of the State Policy of the Russian Federation in the Field of Chemical and Biological Security for the period up to 2025 and beyond have been approved. 'Fundamentals of State Policy in the Field of Chemical and Biological Security of the Russian Federation for the period up to 2025 and beyond', approved on 1 November 2013 by Presidential Decree № 2573-rp has been recognized as invalid.

Government Order № 470-r of 20 March 2019 'On the conclusion of the Agreement between the Government of the Russian Federation and the Government of the Republic of Mali on military cooperation' 
According to paragraph 1 of article 11 of the Federal Law 'On international treaties of the Russian Federation', the Order approves the draft Agreement between the Government of the Russian Federation and the Government of the Republic of Mali on military cooperation, submitted by the Ministry of Defence and agreed with the Ministry of Foreign Affairs and other interested federal executive bodies.

Government Order № 496-r of 22 March 2019 'On signing the Agreement between the Government of the Russian Federation and the Government of the Republic of Belarus on the mutual exchange of geospatial data between the Armed Forces of the Russian Federation and the Republic of Belarus'

President’s Directive № 107-rp of 15 April 2019 'On sending military personnel of the Armed Forces of the Russian Federation to the UN Peacekeeping Force in Cyprus'

President’s Directive № 108-rp of 15 April 2019 'On sending military personnel of the Armed Forces of the Russian Federation to the United Nations Multidimensional Integrated Stabilization Mission in the Central African Republic'

President's Directive № 124-rp of 29 April 2019 'On signing the Protocol between the state members of the Shanghai Cooperation Organization on amending the Agreement between state members of the Shanghai Cooperation Organization on conducting joint military exercises'

Government Order № 1877-r of 27 August 2019 'On signing the Agreement between the Government of the Russian Federation and the Government of Mongolia on counter-terrorism cooperation'

President's Directive № 314-rp of 22 September 2019 'On signing the Agreement between the Russian Federation and the Republic of Abkhazia on financing the expenses on modernizing the Armed Forces of the Republic of Abkhazia' 
Government Order № 2191-r of 27 September 2019 'On signing the Agreement between the Russian Federation and the Kyrgyz Republic on the procedure for monitoring the availability and use of military equipment supplied under the Agreement between the Russian Federation and the Kyrgyz Republic on Promoting Military-Technical Cooperation June 20, 2017.'

According to paragraph 1 of article 11 of the Federal Law 'On international treaties of the Russian Federation', the Order approves the draft Agreement between the Government of the Russian Federation and the Government of the the Kyrgyz Republic on the procedure for monitoring the availability and use of military equipment supplied under the Agreement between the Russian Federation and the Kyrgyz Republic on Promoting Military-Technical Cooperation June 20, 2017, submitted by the Ministry of Defence and agreed with the Ministry of Foreign Affairs and other interested federal executive bodies and previously worked out with the Kyrgyz side.

Government Order № 2520-r of 24 October 2019 'On the conclusion of the Agreement between the Government of the Russian Federation and the Government of the Republic of the Congo on military cooperation'

According to paragraph 1 of article 11 of the Federal Law 'On international treaties of the Russian Federation', the Order approves the draft Agreement between the Government of the Russian Federation and the Government of the Republic of the Congo on military cooperation, submitted by the Ministry of Defence and agreed with the Ministry of Foreign Affairs and other interested federal executive bodies.

Government Order № 2553-r of 28 October 2019 'On approving the Shipbuilding Industry Development Strategy for the period till 2035' 
President's Directive № 381-rp of 8 November 2019 'On signing the Agreement on Joint Engineering Unit for Cooperation in Humanitarian Demining of the Armed Forces of the member states of the Commonwealth of Independent States'

Government Decree № 1761 of 21 December 2019 'On submitting for ratification of the Agreement between the Government of the Russian Federation and the Government of the Syrian Arab Republic on Cooperation in Military Postal and Courier Service'

Government Decree № 1819 of 25 December 2019 'On approving the Rules of treasury support for funds of the State Defense Order in the currency of the Russian Federation in the cases provided by the Federal Law 'On the Federal Budget for 2020 and the 20212022 Planning Period'

Government Decree № 1878 of 27 December 2019 'On approving the Rules of granting in 2020-2022 subsidies from the Federal Budget to organizations of the military industrial complex producing machine-tool products for reimbursement of part of the expenses incurred in the period from 2017 to 2022 for payment of interest on loans received in Russian credit organizations and the State Development Corporation 'VEB.RF', for replenishment of working capital and (or) for financing current production activities'

President's Executive Order № 638 of 31 December 2019 'On Military Attaché Offices at the Embassy of the Russian Federation in the United Republic of Tanzania and the Embassy of the Russian Federation in the Republic of Uganda' 


\section{ABOUT THE CONTRIBUTORS}

ARBATOV, Alexey - Academician of the Russian Academy of Sciences (RAS), PhD in History, Director of the IMEMO Centre for International Security

BOGDANOV, Konstantin - PhD in Engineering, Senior Researcher at the IMEMO Centre for International Security

DIAKOV, Anatoly - PhD in Physics and Mathematics, Chief Researcher (former Director) at the Centre for Arms Control, Energy and Environmental Studies at the Moscow Institute of Physics and Technology

IVANOV, Stanislav - $\mathrm{PhD}$ in History, Leading Researcher at the IMEMO Centre for International Security

KARASEV, Pavel - PhD in Politics, Senior Researcher at the IMEMO Centre for International Security

KUPRIYANOV, Alexey - PhD in History, Senior Researcher at the IMEMO Department of International Political Problems

OZNOBISHCHEV, Sergey - PhD in History, Head of Sector of Military-Political Analysis and Research Projects at the IMEMO Centre for International Security

SHUMILIN, Alexander - PhD in Politics, Director of the 'Europe Middle East' Centre, Chief Researcher at the Department of European Security at the RAS Institute of Europe

TODOROV, Andrei-PhD in Jurisprudence, Researcher at the IMEMO Centre for International Security

TRENIN, Dmitri - PhD in History, Director of the Carnegie Moscow Center

TSELITSKY, Sergey - Researcher at the IMEMO Centre for International Security

ZAGORSKY, Andrei - PhD in History, Head of the Department of Conflict Resolution and Disarmament at the IMEMO Centre for International Security 
Научное издание

\section{RUSSIA: ARMS CONTROL, DISARMAMENT AND INTERNATIONAL SECURITY}

(IMEMO Supplement to the Russian Edition of the SIPRI Yearbook 2019)

Специильное приложение к Ежегоднику СИПРИ 2019

Ответственные редакторы:

Арбатов Алексей Георгиевич,

Ознобищев Сергей Константинович

Редактор: Евтодьева Марианна Георгиевна

Редактор перевода: Гейер Леон

Рекомендовано к печати Ученым советом ИМЭМО РАН

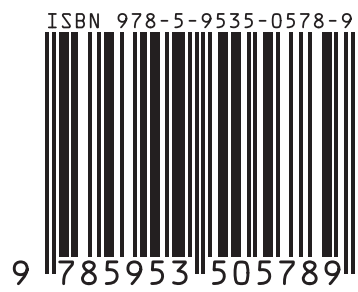

Подписано в печать 08.10.2020.

Формат $170 \times 240$. Печать офсетная.

Объем 21,75 п.Л., 8,7 а.Л. Тираж 300 экз. Заказ № 25/2020

Издательство ИМЭМО РАН

Адрес: 117997, Москва, Профсоюзная ул., 23 